

\section{DISCLAIMER}

This report was prepared as an account of work sponsored by an agency of the United States Government. Neither the United States Government nor any agency Thereof, nor any of their employees, makes any warranty, express or implied, or assumes any legal liability or responsibility for the accuracy, completeness, or usefulness of any information, apparatus, product, or process disclosed, or represents that its use would not infringe privately owned rights. Reference herein to any specific commercial product, process, or service by trade name, trademark, manufacturer, or otherwise does not necessarily constitute or imply its endorsement, recommendation, or favoring by the United States Government or any agency thereof. The views and opinions of authors expressed herein do not necessarily state or reflect those of the United States Government or any agency thereof. 


\section{DISCLAIMER}

Portions of this document may be illegible in electronic image products. Images are produced from the best available original document. 


\section{NOTICE}

This report was prepared as an account of work sponsored by an agency of the United States Government. Neither the United States nor any agency thereof, nor any of their employees, makes any warranty, expressed or implied, or assumes any legal liability or responsibility for any third party's use or the results of such use of any information, apparatus, product, or process disclosed in this report, or represents that its use by such third party would not infringe privately owned rights. 


\title{
DOE/Solar Export Opportunities Workshop
}

\author{
Sponsored by \\ U.S. Department of Energy
}

Coordinated by

Solar Energy Research Institute

\section{Location}

Sheraton-Biltmore Hotel

Atlanta, Georgia

January 8-10, 1979 


\section{PREFACE}

The Solar Energy Research Institute (SERI) and the International Solar Commercialization Working Group (ISCWG) of the Office of Conservation and Solar Application (CS) of the Department of Energy (DOE) conducted the Solar Export Opportunities Workshop to bring together persons from government agencies and the U.S. solar industry to initiate dialogue needed to create and implement programs facilitating the export of U.S. solar technology, hardware, and services. The workshop was intended as the first of a series of related meetings devoted to such topics as: strategies and problems associated with doing business in specific regions of the world; mechanics of doing business overseas; and preliminary issues cited below. These meetings are components of a comprehensive international commercialization program being undertaken by DOE to accelerate the introduction of solar-related technologies throughout the world.

The objectives of the first meeting were as follows:

- to provide a forum in which solar industry and interested persons from the government sector could explore ways of entering the international marketplace;

- to provide an opportunity for industry representatives to obtain information about existing, export-related programs from key government and financial institution persons; and

- to provide an opportunity for industry representatives to discuss export-related marketing strategies, problems, regulations, competitions, and personnel with key government and financial institution persons.

The workshop achieved these objectives quite effectively. A major result of the meeting was the identification of problem areas and needs as seen by the industry. The following needs were determined: more timely and useful information about the international marketplace; mechanisms to keep the industry informed about and involved in programs which may have export business overtones; ways to more effectively display the industry capabilities to potential customers overseas; and some means of assisting the industry in meeting the high costs of doing business in the international marketplace.

A number of preliminary issues were generated from the various workshop sessions. The principal issues which could form the basis for future workshops are summarized below.

\section{Information}

To what extent should the U.S. government make a special effort to acquire and disseminate data to U.S. industry, including training programs and data packages pertaining to solar export and international commercialization? Could such data-and other related information obtained by the U.S. government or under government auspices for U.S. industry-be protected from foreign competitors and governments?

\section{Financial and Promotional Assistance}

In addition to information, the U.S. solar industry needs outside help in order to be competitive overseas. Such help could be in the form of financial incentives (i.e., tax relief, low-interest loans, $R \& D$ and other contracts, rewards and other aid to exporters). Stronger support also could be provided in the form of trade fairs and 
missions, export subsidies, and promotion by U.S. officials abroad. In addition, more attention should be focused on U.S. regulatory practices on solar exports to increase incentives and decrease barriers for U.S. companies interested in solar export markets. Should the U.S. government provide special effort to the U.S. solar industry through financial and promotional assistance, and if so, to what extent?

\section{Industry Input}

It is widely believed in the U.S. solar industry that the U.S. government is paying too little attention to the views and needs of industry during the process of planning and conducting U.S. foreign energy activities, particularly AID and DOE bilateral and multilateral agreements. A meaningful role could be determined for various associations representing solar industry as to their specific involvement in these agreements as well as participation in ISCWG activities. What should be the nature of U.S. solar industry involvement in providing a viewpoint and requirements to the U.S. government to ensure consideration in the formulation and conduct of such agreements and activities?

\section{Technology Transfer, Patents, and Licensing Issues}

The U.S. solar industry has an advantage over many countries in certain fields of higher technology. If transfer of technology abroad by the U.S. government occurred without regard for the interest of U.S. industry, it could easily and rapidly erode this advantage. In time, potential customers may become successful competitors. Should the U.S. industry participate in the planning and decision-making processes that could lead to such government transfers of technology, and if so, in what manner and in regard to what types of technologies?

\section{An Extraordinary Effort}

At present, the U.S. solar industry receives a minimum of special attention from the Federal Government on export market development. Other segments of the energy sector (such as the nuclear industry) enjoy special advantages and strong financial support. Should the U.S. government make an extraordinary effort to provide the U.S. solar industry with the export assistance necessary for a strong and rapid market development? This would encourage a near-term export industry based on, and stimulating, a strong domestic market and industry.

Robert C. Spongberg, SERI

William L. Corcoran, DOE

Chairmen

DOE/Solar Export Opportunities Workshop 


\section{ACKNOWLEDGEMENTS}

In light of the desire to have the Solar Export Opportunities Workshop truly a working meeting, original plans did not provide for proceedings to be published. Many requests for proceedings prompted the change in plans. Producing proceedings after the fact is always quite difficult and a vote of thanks should go to the speakers and all others who participated in this effort. 


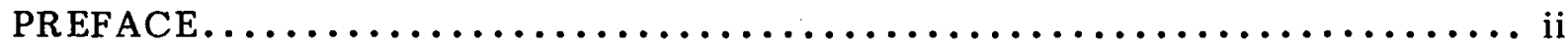

ACKNOWLEDGEMENTS $\ldots \ldots \ldots \ldots \ldots \ldots \ldots \ldots \ldots \ldots \ldots \ldots \ldots \ldots$ iv

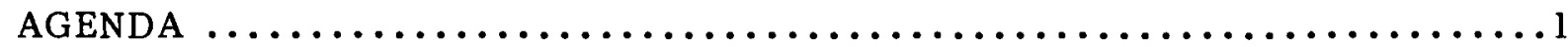

KEYNOTE AND OTHER STATEMENTS BY GUEST SPEAKERS

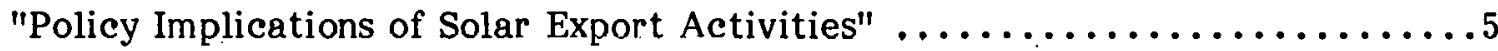
Sarah Jackson, Department of Energy, Office of International Affairs

"Solar on the Move-Despite DOE".......................... Congressman Richard Ottinger, N.Y.

"The Roles of the Trade Associations"...........................15 Sheldon Butt, Solar Energy Industries Association

\section{SESSION I: U.S. GOVERNMENT OVERVIEW}

"Overview-Department of Energy".............................. 19 William Corcoran, Department of Energy, Office of Conservation and Solar Applications

"Activities of the Department of State" ..........................25 Martin Prochnik, Department of State, OES

"Activities of the Department of Commerce" .......................27 Richard Garnitz, Department of Commerce, Office of International Marketing

"Overview of the Activities of the Export-Import Bank". ................ 31 John Bierman, Export-Import Bank

"Activities of the Agency for International Development"...............37 Stephen Klein, Agency for International Development

"Activities of the Agency for International Development"...............41 Jerome Bosken, Agency for International Development

\section{SESSION II: DOE CURRENT ACTIVITIES/STATUS REPORTS}

"Overview of DOE Solar Cooperative International Arrangements" $\ldots \ldots \ldots \ldots 45$ Jack Vanderryn, Department of Energy, Office of International Affairs

"Report of the Domestic Policy Review International Panel" ..............59 Jack Vanderryn, Department of Energy, Office of International Affairs

"Cooperative Agreements as Benefit to U.S. Industry" ................71 Lloyd Herwig, Department of Energy, Energy Technology

"Commercialization Activities-International Solar Commercialization Working Group (ISCWG)" . .................................95 William Corcoran, Department of Energy, Office of Conservation and Solar Applications

"The International Energy Development Program" ...................113 A. Nelson Tardiff, Department of Energy, Office of International $\Lambda$ ffairs 
"Export Potential for Photovoltaic Systems" $\ldots \ldots \ldots \ldots \ldots \ldots \ldots \ldots \ldots \ldots \ldots \ldots$ Richard S. Campbell, Battelle

\section{SESSION III: ACTIVITIES OF GOVERNMENT FINANCIAL INSTITUTIONS}

"Energy-Related Activities of the World Bank" .....................121 Vincent Riley, World Bank

"Specific Programs of the Export-Import Bank"..................... Francis E. Wilson, Jr., Export-Import Bank

"International Activities of the Small Business Administration" ............129 Fred S. Fleischman, Small Business Administration

SESSION IV: THE INDUSTRY-INDUSTRY CASE STUDIES

"Small Business Case Study" .................................131 Gary Neuner, Acurex Corporation

"The Thermo Electron Experience" ..............................147 John T. Keiser, Thermo Electron Corporation

"Advanced Energy Programs" ................................. 155 George P. Hellhake, General Electric Company

\section{SESSION V: ROLES AND RECOMMENDATIONS}

Workshop Group Reports

Group 1: Robert W. Willis, Solenergy Corp....................167

Group 2: John Day, Strategies Unlimited $. \ldots \ldots \ldots \ldots \ldots \ldots \ldots \ldots \ldots . \ldots \ldots$

Group 3: Mike Cucurullo, Grumman International Co $\ldots \ldots \ldots \ldots \ldots \ldots 171$

Group 4: Michael Belanger, Exxon Enterprises, Inc..............173

Group 5: Jonathan P. Schlesinger, Northrup, Inc. ............... 175

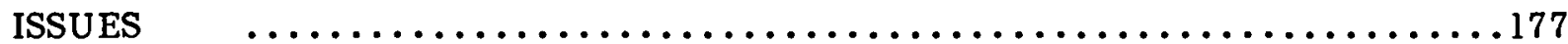

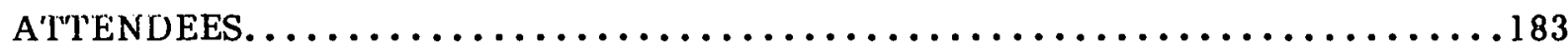


Agenda 


\title{
DOE/SOLAR EXPORT OPPORTUNITIES WORKSHOP
}

\author{
January 8-10, 1979 \\ Atlanta, Georgia
}

\section{AGENDA}

Monday, January 8, 1979

4:00 - 8:00 p.m.

Registration

Tuesday, January 9, 1979

7:00 a.m.

$9: 00-9: 40$ a.m.

$9: 40-10: 00$ a.m.

10:00 - 12:30 p.m.

12:30 - 1:30 p.m.
Registration

Keynote/Welcome

Informal Discussion and

Coffee

\section{SESSION I}

U.S. GOVER NMENT OVERVIEW - PANEL DISCUSSION

William L. Corcoran, DOE Moderator
Sarah Jackson, DOE/IA Dept. Asst. Secretary Int'l. Policy

Development

Panel Members:

Murtin Prochnlk, Dept. of State

Richard Garnitz, Dept. of Commerce

Jerome (Sam) Bosken, AlD

Stephen Klein, Agency for International Development

John Bierman, Export/Import Bank

Jack Vanderryn, DOE/

International Affairs

Luncheon 


\section{SESSION II}

$1: 30-3: 00$ p.m.

3:00-3:30 p.m.

3:30 - 5:00 p.m.

7:00 p.m.

Wednesday, January $10,19 \overline{9} \dot{9}$

8:00 - 9:45 a.m.
DOE CURRENT ACTIVITIES/

STATUS REPORTS

Overview of DOE Solar

International Arrangements

Report of the DPR

International Panel

(Domestic Policy Review)

Cooperative Agreements as

Benefit to U.S. Industry

Commercialization

Activities - International

Solar Commercialization

Working Group (ISCWG)

LDC Programs (Less

Developed Countries)

Informàl Discussion and

Coffee

SESSION III

ACTIVITIES OF GOVERNMENT FINANCIAL INSTITUTIONS

Banquet

"Solar on the Move"
Jack Vanderryn, DOE/IA

Jack Vanderryn, DOE/IA

Lloyd Herwig, DOE/ET

William L. Corcoran, DOE/Office of Solar Applications
A. Nelson Tardiff, DOE/IA
Vincent Riley, World Bank

Francis E. Wilson, Jr.

Export/Import Bank

Fred S. Fleischman,

Small Business Adm.

Speaker:

Richard L. Ottinger,

U.S. House of

Representatives

Congressman from

New York

\section{SESSION IV}

THE INDUSTRY

Industry Case Studies
G. J. Neuner, Acurex

J. T. Keiser, Thermo

Electron Corporation

George Hellhake, GE 

9:45 - 10:00 p.m.
10:00 - 12:00 p.m.
12:00 - 1:30 p.m.
Informal Discussion and
Coffee
THE INDUSTRY - Continued
Joint Ventures and Other
International Arrangements
Experiences and Attitudes
Luncheon
"The Roles of the Trade Associations"

l:30 - 3:00 p.m.

3:00 - 3:30 p.m.

3:30 - 5:00 p.m.

5:00 p.m.

\section{SESSION V}

ROLES AND

RECOMMENDATIONS

Attendees participated in smaller groups to discuss specific components of a "blueprint" for the futurewhat might be done to define effective government/ industry requirements to facilitate the export of solar technology, hardware and services.

Informal Discussion and Coffee

\section{SESSİON VI}

SUMMARY

Session V Group Meeting

Reports

Concluding Remarks

Workshop Adjourns
Speaker:

Sheldon Butt, President Solar Energy Industries Association 
THIS PAGE INTENTIONALLY LEFT BLANK 
Keynote and

Other Statements

by

Guest Speakers 


\section{POLICY IMPLICATIONS OF SOLAR EXPORT ACTIVITIES}

Sarah Jackson, Deputy Assistant Secretary

International Policy Development

Department of Energy, Office of International Affairs

washanftion, $D C$

I appreciate the opportunity to participate in this dialogue between the private and public sectors on a subject of growing policy interest. I shall attempt to provide a context for later discussions on international solar commercialization, $R \& D$ cooperation in solar technologies, and development assistance in renewable energy technologies.

Industrial and developing countries presently face great uncertainties in planning their energy future. Although general international agreement exists on the goal of achieving secure and adequate energy supplies at reasonable costs, our government and others face major difficulties in overcoming the political, economic, and environmental constraints to the development of indigenous energy supplies and the increased efficiency of energy use. Congressional and public debates over energy product prices and environmental regulations bear witness to these difficulties.

Nevertheless, the Administration is determined to press vigorously ahead to deal with our own and the global energy problem. After a difficult legislative campaign, we now have a national energy program that will reduce oil imports by $21 / 2$ to $3 \mathrm{Mbbl} / \mathrm{d}$ in 1985 below what they would have been in the absence of this legislature. At the Bonn Economic Summit, our major western industrial countries also affirmed their commitment to take necessary action to reduce their dependence on imported oil. The Seven Summit Countries stressed the long-term importance of coal and pledged to increase coal production by two-thirds. They also emphasized the indispensable contribution nuclear power could make in reducing oil-import dependence.

The President and his colleagues also endorsed expanded $R \& D$ efforts to hasten the development of new and renewable energy sources. These leaders asked the World Bank to study possibilities for increasing hydrocarbon exploration in developing countries. They pledged to develop a coordinated program to bring renewable energy technologies into use and to elaborate the details of this program within one year. The recent events in Iran and the OPEC price increase have reinforced the need for early action to accelerate the global energy transition to alternative, renewable energy sources.

With our large commitment to solar energy, the United States exerts a powerful demonstration effect on other countries. DOE expenditures on renewable energy technologies, including commercialization, may exceed $\$ 500$ million in FY79, a phenomenal increase over that of just a few years ago. However, solar resources, like oil resources, are not evenly spread over the globe. The United States is fortunate to have abundant sunshine, wind, and biomass resources in many parts, but other industrial countries in Europe and Japan are not so lucky. Consequently, these countries are orienting solar development activities toward markets in the developing countries where energy demand is increasing rapidly and solar resources are abundant. U.S. companies are beginning to look seriously at these markets. The U.S. government intends to be helpful to industry in this effort, and in fact, to encourage industry to push ahead rapidly in this area. Workshops and meetings such as this one are essential to developing a true government/industry partnership. Competition among industrial countries, if channeled into constructive avenues, can help speed the development and introduction of solar technologies, both at home and in the developing countries. 
A U.S. international solar strategy is beginning to emerge that supports our basic energy, foreign policy, and commercial objectives. The three basic components of this strateg are commercialization, $R \& D$ cooperation, and development assistance. Through DOF the Agency for International Development (AID), the Department of State (DOS), and other agencies, the United States is developing programs to identify applications and markets for solar technologies; to maximize technical progress in developing marketable technologies; and to help poorer countries in transferring, adapting, and in some cases, manufacturing solar technologies appropriate for their circumstances. These three areas are mutually supportive and need to be effectively integrated if we are to be successful in our goal of accelerating the use of solar technologies.

A major emphasis of U.S. international solar programs is R\&D cooperation with other industrial countries, primarily within the framework of the International Energy Agency (IEA). These activities serve to compliment and support our domestic technical program goals, as well as our foreign policy interests. However, because of the strong export orientation of other IEA countries, cooperative activities within the IEA need to be carefully evaluated as to their current and potential impact on the export positions of the participating countries.

The Carter Administration also has a strong interest in cooperation with developing countries and energy is viewed as an area where constructive, mutually beneficial discussions can take place. Particular emphasis has been placed on renewable energy sources; for example, at the Summit and in Secretary Vance's speech at the United Nations (UN) General Assembly endorsing the UN Conference on New and Renewable Energy in 1981. Congress has authorized expanded AID programs in this area and their budget has grown significantly over the past two years.

DOE intends to play an active role in the development and implementation of Administration energy programs with developing countries. We are planning to intensify activities in the following four areas:

1. cooperative research and development with technically advanced or capital surplus developing countries;

2. R\&D in energy systems for Less Developed Countries (LDC) markets;

3. cooperative analyses of energy needs, resources, and uses with developing countries; and

4. commercialization of suitable, especially renewable energy technologies.

Each of these four areas is described below.

\section{Cooperative R\&D}

We are progressing with the establishment of cooperative $R \& D$ activities in the energy field with two groups of developing countries: those with relatively advanced technical capabilities such as Mexico, Brazil, and India and those with substantial capital surpluses but less-well-developed technological bases such as Saudi Arabia and Venezuela. These so-called "upper tier" developing countries tend to be the most significant from an energy production and consumption standpoint. They are also of growing importance as markets for U.S. exports. In 1977, 36\% of U.S. exports were destined for developing countries. The ten leading markets (in order of value) in 1977 were: Mexico, Saudj 
Arabia, Venezuela, Iran, Brazil, South Korea, Taiwan, Hong Kong, and Singapore. Together they accounted for $57 \%$ of total U.S. exports to developing countries. While AID assistance programs focus on rural development in the poorest countries, these upper-tier countries desire to improve the technological base to advance their industrial development. They seek advanced technologies to reduce dependence on imported oil and, in the case of the oil exporters, to conserve their domestic petroleum resources for export and high-value petrochemical and other domestic uses. Solar energy R\&D activities are underway or planned with Brazil, Saudi Arabia, Mexico, India, and South Korea. In addition to such bilateral activities, we are actively involved in the multilateral programs of the IEA, which has recently invited selected developing countries to participate on a regular basis; Mexico, for example, has recently joined in an IEA geothermal project.

\section{R\&D on Systems for LDC Markets}

Some of the current and planned renewable energy systems $R \& D$ work in the United States have utility for developing countries and could easily be adapted to their conditions. However, there is clearly a need for additional R\&D by U.S. industry on energy technologies specifically designed for operation in developing countries, particularly small-scale systems. RD\&D oriented to the needs and requirements of the developing countries would be responsive to the President's commitments and the recommendations in the recent Domestic Policy Review on Solar Energy. Such RD\&D by U.S. industry should receive broadened DOE support. This activity could involve testing and selected demonstrations of such technologies in developing countries, either independently by DOE, or in concert with AID or the newly proposed Foundation for International Technical Cooperation (FITC). FITC, which is still in the planning stage, could play a significant role as a bridge between DOE and the overall U.S. development assistance effort. Such a role would increase our flexibility in dealing with the non-AID recipient, upper-income, developing countries.

\section{Cooperative Analysis of Energy Needs, Resources, and Users}

The radleal changes in the economics of energy since 1973 have necessitated a reevaluation of previous energy strategies for most developing countries. In a number of cases, countries have not conducted a comprehensive examination of their energy needs, uses, resources, and options. Energy sector and subsector analyses are viewed as a vital element in U.S. cooperative programs.

Since September 1977, DOE has been engaged in planning and managing a pilot program of cooperative analysis of energy needs, resources, and uses with Egypt and Peru. These joint analyses, discussed later in this workshop, can serve as the first step in defining priorities for applicable technology $R D \& D$ activities or for assistance efforts by the World Bank or AID. They also could support a U.S. follow-on cooperative program involving demonstration or testing of new technologies that are applicable in a particular developing country. The commercial potential of such a subsequent program could be very significant. If the President approves continuation of this type of energy cooperation, which has been endorsed by the Congress, the World Bank, and the European Economic Commission, new countries will be selected for similar joint assessments in FY79 and FY80. 


\section{Commercialization}

With regard to commercialization, certain solar and geothermal technologies will probably be economically viable in developing countries earlier than in the United States, primarily because commercial fuel prices are artificially depressed in this country. Thus, the development of an overseas market may provide a stimulus to efforts to penetrate U.S. domestic markets. To support the definition of a program to accelerate international solar energy utilization and commercial opportunities, DOE is working with the DOC and other federal agencies. Such agencies as the Export-Import Bank (Ex-Im Bank) and the Overseas Private Investment Corporation are also taking an increased interest in U.S. solar industry exports and investments. Overall barriers and incentives to solar exports need to be identified for individual countries. The responsible DOE program organizations are analyzing the potential market for solar technologies in both the industrial and devoloping worlds. We are now developing a strategy to ensure coordination of these market activities with other DOE solar activities within the context of overall efforts to advance U.S. international energy and foreign policy interests.

I would like to conclude on both a note of optimism and a note of caution. We live in a world in which population growth and desires for economic progress will exert increasing pressures on energy resources, particularly petroleum, in the future. Renewable energy resources are available to meet many of these needs, and we must push ahead rapidly in our eff or ts to develop economically, technically, and socially viable solar systems. These efforts, however, must be based on a clear understanding of the type of economic growth and development that we want to achieve. Past models of industrialization are increasingly called into question, both for normative as well as resource and environmental reasons. Answers must be pursued at various international and domestic levels to such basic questions as:

- who will require the energy?
- $\quad$ how mind of energy is most appropriate?
for what purpose is the energy needed?
- for how long and at what time is it required?

Attempting to answer these questions will help us define the proper role for solar technologies.

Finally, we need to temper our zeal to spread solar technologies worldwide with an appreciation of the problems in transferring many solar technologies to developing countries, particularly at the rural village level. The attitudinal and institutional changes necessary to achieve widespread public acceptance and use of these technologies may be great indeed. The Atoms for Peace and subsequent programs designed to spread the benefits of the peaceful atom illustrate the many problems as well as opportunities that may be inherent in such campaigns.

However, we shall never know the real potential for solar energy until we begin installing and demonstrating systems in developing as well as industrialized countries. We urgently need information on the life-cycle costs and performance of solar systems under various conditions. Only then can we make the financial and technical decisions on the most appropriate type of technologies for large-scale commercialization. Industry has a major role to play in this endeavor but government can help. I hope that each of us will leave this workshop with a determination to speed the process by which the world becomes 
increasingly dependent on renewable energy resources. Our task, in short, is to telescope the time-frame of the energy transition period. 
THIS PAGE INTENTIONALLY LEFT BLANK 
Congressman Richard Ottinger, N.Y. U.S. House of Representatives, wash

It is good to see that the solar industry is in such fine shape-despite the DOE. I think Helen Drusine put it well in her article on "Solar Politics" in the January issue of OMNI where she starts out:

Despite overwhelming popular support, as evidenced by a recent Harris poll showing 80 percent approval, solar energy is still viewed by the federal bureaucracy as an errant stepchild. The Department of Energy, created in October 1977, was directed "to place major emphasis on the development and commercial use of solar ... (and) renewable energy resources." Instead, we have a program that drif ts along like a piece of intergalactic flotsam, its direction unknown and its future questionable.

DOE is the third largest federal agency. With a $\$ 12$ billion budget, it supports 20,000 employees directly and countless others throughout the country via grants and research project funding. Many experts claim that solar is the safest and sanest solution to America's crisis-prone energy condition, but the potential of sun power is being shuffled into a hold file by program managers at DOE.

The Administration still issues rosy words about its commitment to solar:

Yet solar will get only about $\$ 470$ million or 3 percent of the DOE budget. The initial administration proposal was for $\$ 400.5$ million, a decrease of 10 percent from last year. Carter increased this figure only when it was apparent that Congress would appropriate more than $\$ 500$ million.

[The] Solar Energy Industries Association estimates that 11 million homes will have solar hot-water heaters by 1985 . DOE's forecast is only one tenth that many. Even President Carter's original target of 2.5 million is being cut to 1.3 million. This is less than the goal for California alone, which hopes to have 1.5 tn 2 million homes using solar energy by 1985 .

DOE's biggest single budget cutback for FY79 was a $45 \%$ reduction in the solar energy heating and cooling demonstration program-from $\$ 65.8$ million to $\$ 36$ million. Yet experts agree that hundreds of federally-funded solar heating demonstrators are still needed across the country to provide consumers, builders, and lenders a firsthand opportunity to see cost-effective solar heating systems in operation. The House Science and Technology Committee added $\$ 23$ million to the demonstration budget over three years to try and repair the damage.

The second class citizenship of solar energy in DOE unfortunately continues, and in a number of instances has become overt. Although Secretary Schlesinger, who does not seem to have much commitment to solar energy, called the transition to renewable energy a "great adventure," his second-in-command, John O'Leary, completely blackballed solar development when he told the American Public Power Association in October that solar had no significant contribution to make in this century-a shocking 
display of solar "ignoramus-ship" in DOE. I have no doubt this attitude reflects the real views of the majority of those who run the department. Our efforts, both in Congress and the private sector, quite clearly have to be to dig into the solar age-albeit DOEkicking and screaming.

By the way, the newspapers have reprinted a claim by President Carter at the Memphis miniconvention that solar energy would have a $\$ 1$ billion program next year. I will have to see it before I believe it. The last Administration's announced increase for solar energy was, in reality, a huge cut.

I sit on the Science and Technology Committee which has been responsible for solar research and development increases and on the Energy and Power Subcommittee of the Interstate and Foreign Commerce Committee where the principial accomplishments have been inclusion of solar energy in legislation dealing with energy verformance standards for new buildings, in the conservation programs for existing schools and hospitals, and in the N.E.A. utility program. Many of my colleagues and I have joined the solar coalititon. During the last session, Congress passed over 30 pieces of legislation dealing with solar energy development. My particular contribution was legislation for the use of solar energy in federal buildings and for the federal procurement of solar technologies.

Solar energy looks as though it has moved through Congress, but none of us can relax. Although there are tax credits for residential and commercial use, the Internal Revenue Service forms do not allow credits for passive solar applications and, as many of you are aware, the business tax credit allows a $20 \%$ investment credit for process heat but only $10 \%$ for solar heating and cooling. The Small Business Administration has yet to make funds available for the solar loan program. Procurements for federal buildings are moving at a snail's pace.

The beginnings of an international solar program exist, but coordination and funding are essential. Through Title V of the Nuclear Non-Proliferation Act, the United States is called to initiate programs with developing countries to emphasize solar energy. Yet this funding must be made available by DOE. The International Development and Food Assistance Act of 1977. added Section 119 to the Foreign Assistance Act calling for the use of small-scale, decentralized, renewable energy sources with developing countries. The 95 th Congress amended the Export-Import Bank Act of 1945 by adding a section directing the appointment of an officer to advise the bank on always of promoting exports of renewable energy technologies. These are just fledgling programs. DOE's ISCWG has a responsibility to coordinate and utilize those resources and to make this promise a reality.

You are naturally interested in the development of the solar market abroad and in the less-developed countries. But surely the American Petroleum Institute and the Atomic Industrial Forum are not going to sit quietly by as foreign markets are developed for solar energy. This sume cadre after all has lobbied very successfully through the years for conventional subsidies. So what are we going to do?

First, we are going to have to help the American people understand what has happened in the past with the development of energy in this country-and the dismal record of our government in promoting solar technologies-as well as the great and real solar potential that exists. In a recent poll, $94 \%$ of the public supported the rapid development of solar energy. How many of these people, however, are aware of the massive production subsidies the Federal Government gives to conventional energy sources and the lack of enthusiasm for solar energy in the top echelon of DOE? Some conventional subsidies 
include accelerated depreciation, depletion allowances, foreign tax writeoffs, intangible drilling credits, and a host of others. The March 1978 Battelle report estimates that in the last 50 years these subsidies amounted to $\$ 200$ billion - 100 times the amount utilized for solar. Along with subsidies, marginal pricing policies need to be considered in the solar cost equation. If everyone paid for oil at the world price, for gas at the price of imports, and for electricity at roughly the cost of power from even the least expensive new power plants, the nation's annual energy bill would be $\$ 70$ billion higher-about $\$ 1$ billion per quad. If society subsidized solar technologies to this same degree, the impact would certainly be revolutionary. Real progress demands just a fraction of the assistance given conventional technologies. Solar energy now makes economic sense at the margin. Society wants to obtain as much energy as possible per dollar of investment. The question is which new investment really produces the bang for the buck. The answer is obviously solar energy.

Second, we have to have a federal policy that is committed to solar. This month the report of the Interagency Task Force, known as the Domestic Policy Review on Solar Energy, will go to the President. Depending on what he chooses from the variety of options, solar energy could continue business as usual contributing no more than $10 \%$ to national energy needs by the year 2000 or it could contribute more than $25 \%$ placing us on a path for a society whose dominant form of energy will come from the sun. We have to get to the President on this-and to the Congress.

Here are some of the crucial things the President could do as a result of the Domestic Policy Review:

- He could announce that it will be the national policy to supply up to one quarter of our energy from solar sources by the end of the century. Setting such an ambitious but achievable goal will send clear signals to all sectors of society as well as to other countries.

- He could recommend to Congress a whole array of incentives to help compensate for the discrimination faced by solar energy in the marketplace. These include such measures as establishing a solar energy development bank to provide longterm, low-interest loans to residential and commercial users of solar systems and tax credits for industrial applications for passive and active solar energy and for biomass.

- He could prepare to mandate the use of solar energy if voluntary programs and incentives fail to achieve expected goals. San Diego has already approved a referendum to require solar hot water heaters in all new construction. Other countries such as Australia and Niger require solar systems in new construction.

- He could establish a White House level policy council to coordinate interagency solar efforts.

- He could create a citizens' solar commission to directly involve all sectors of society in the solar transition.

We must all watch with great care what happens in the next months. We are at a watershed without energy policies. The last weeks in Iran have again clearly emphasized this. 
I urge all of you to become political activists. We need you to lobby the cause of solar energy. The nuclear and oil "boys" do their stuff-so don't be shy. Congress needs you to put the pressure on when solar legislation comes to the floor. We need you to testify in committees-to tell us about the latest solar developments, and the needs of business and consumers. The Administration needs to hear that you support a strong solar commitment. You should write the President and speak to his principal advisors, write letters-to-the-editors, and make certain your local newspapers, radio, and TV give adequate coverage to solar developments. My friend, Tony Adler, who heads the Solar Energy Industries Association Governmental Affairs Committee, has given this effort a start. I applaud his and the Committee's work. But it is just a start. Let us all work together. 


\title{
THE ROLES OF THE TRADE ASSOCIATIONS
}

\author{
Sheldon Butt, President* \\ Solar Energy Industries Association

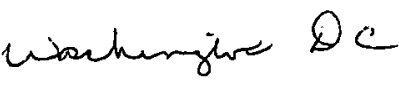

The Solar Energy Industries Association (SEIA) represents the interest and concerns of the solar industries. As a typical trade association, our basic purpose is to try to do the things that a group of people related by their business or businesses may best do together in order to enhance their individual profitability. SEIA represents approximately $90 \%$ of U.S. production volume of the various solar technologies discussed in this workshop. SEIA is comprised of many divisions including a Photovoltaics Division, a Solar Thermal Division, an Active Cooling and Heating Division, and an Agricultural and Industrial Process Heat Division. The association consists of both small and large firms with most of the small firms hoping to become large firms as the industry grows.

In terms of foreign trade our objectives as an industry generally coincide with the objectives of the federal government. We want to create and sustain viable, profitable, international markets for our products. We want to cooperate in a partnership with Federal agencies in areas such as the formulation of policy; we recognize that we will have to live with policies after they are formulated and it has a great deal to do with whether we suffer or prosper. We want to be involved in negotiations relating to foreign trade since our property will be affected by any decisions.

You probably have detected in some of the comments made by various people that those of us in industry do not necessarily trust all of you in federal government. One way we can learn to trust you is by becoming better acquainted because by and large most of the people in the federal government are dedicated public servants and I'm sure we'll find this to be true. We want to work as partners with government, both in the planning process and in the area of implementation of solar programs.

At the moment, the SEIA International Trade Committee is the specific vehicle for coordination with the federal government's activity. We may find it expedient to form a series of committees later, depending on how rapidly we progress in this beginning partnership. We may want to form a specialized committee in the area of photovoltaics, for example, where the concerns and opportunities are perhaps somewhat different than they are in some of the other areas. We consider that being taken into partnership is a prerogative-even a constitutional right-that we have as citizens and as taxpayers, but we have to go beyond that in talking about why we should be partners with you. First of all, we are in the business. We produce and market the product, and deal with all the problems of credit arrangements, product quality, standards, and regulations. To quote what the speaker from the Department of Commerce (DOC) said yesterday: we are "the crass commercial interest." We are involved in one type of negotiations or another, although not necessarily international, every day. Negotiating is how you do business.

*Sheldon Butt is Director of Solar Marketing at Olin Brass and has been at Olin for 30 years. 
You negotiate for an order. I don't wait for someone to mail me an order. I go out and negotiate with the customer for an order. We know about negotiating. We are professionals in this area in our own particular.way and in a manner somewhat different from the professional negotiating credentials of State Department people or DOE people. They have their area of negotiating expertise; we have ours. Together we can do a better job. I think it was George Szego in a private discussion yesterday who brought up the point that one Arab can out-negotiate five Americans, so I guess we will have to send six to avoid being out-negotiated. Fortunately, the population of the United States is more than six times as great as the population of Saudi Arabia. In many ways, we are perhaps the best judge of the potential commercial and business impacts of the plans you are making, the negotiations which you are conducting, and programs you are considering. We can provide you with detailed (sometimes perhaps to the point of surfeit) knowledge of the practical aspects of solar applications as well as the status of research and development activities in all of these various solar technologies. These are the things that we, in effect, can bring to the partnership. In our area of concern, exports not only have an impact on the somewhat intangible thing known as "balance of payments", but also represent something a whole lot more to us directly and individually: they are a potential part of our livelihood. Recognizing that, we do indeed want to be your partners.

New industries, such as the solar. industries, are faced with unique opportunities to develop new and innovative measures, methods, and relationships; these can be measures of cooperation between industry and government. There should be no stigma attached on either side to cooperation. We can deal with each other openly. One of the things that we have here is an opportunity: we have not really gotten to the "us and them" kind of relationship which exists in many established industries where industry trade associations exist primarily to keep the federal government away from them. They are truly defensive organizations. Many industries and the federal agencies with which they interact have become so polarized that a meaningful dialogue is no longer possible. Certainly this is not true of all the established industries, although it applies to many of them. The time to establish a pattern is in the period when the industry or the business is still in its infancy. People in general tend to be imprinted with behavioral patterns very early in life, in some measure before they can even talk, and I think this is true of industries and the government agencies with which they interact. The behavioral patterns that we can learn now through cooperation may well be permanent and if they are good, that is fine; if they are bad, they are liable to be bad forever so now is the time to initiate a partnership arrangement.

I have to express a caveat here: when you work with us, one of the things you have to recognize is that solar is indeed a small and struggling industry or group of industries and that the trade association is correspondingly understaffed, underfunded, under-mosteverything-else, including under the gun. There are people who like us but who do not like the Atomic Industrial Forum. We do have that going for us. I think Congressman Ottinger brought this out last night. Not only are you going to have to be our partners, but you are going to have to help us help you as well. We can talk about the details of that later, but again-the purpose and thrust-we are here because we want to enter into a meaningful partnership relationship with you. 
International trade is like an arena with some rather substantial gladiators. Very aggressive trade practices are fundamental government policy in many countries. Such countries protect their home markets so our opportunities therefore are largely in third country markets. They have dealt historically with balance of trade problems long before we learned there was such a thing. They operate more professionally than we as a nation or as a group of individuals do. We have been very lucky because we have had, historically, surplus products to export. We still do in terms of agricultural resources. People have to eat and we do not have to try hard to sell these. Through our own ingenuity we have gotten so far ahead of the world in some specific areas of technology that we have not had too difficult a time competing in these areas, although our position in many of them does seem now to be eroding. One of the things that bothers me in terms of U.S. posture is that when the United States finally comes to grips with enforcing anti-dump legislation which has been on the books for something over 50 years, and we are at the point where we are going to do something about it-we are going to lay on the countervailing duties-someone comes from the Japanese Embassy and threatens to start a trade war if we do. What are they saying? There has been a trade war for $\mathbf{5 0}$ years. Two wars cannot be started concurrently. A new war cannot be started until peace is made from the old war. These people have been in trade wars with us, whether we are aware of it, for years, and we simply are going to have to take measures to compete. Our problem is that we do not perceive of ourselves as fighting the same war and are not willing to talk about using the same weapons. If there is a trade war, they will quit buying food and all go hungry-who is kidding who? If we make it tough for them to dump Toyotas, we should remember that we do not need Toyotas half as bad as they need soybeans.

So one should discuss our status in terms of aggressiveness in international markets as a nation, as individual companies, as individual government agencies, to the solar industry. My view is that we have a number of assets in the solar industry today. We feel we have better technology. Not uniformly or 100\%, but generally. At today's exchange rates, we probably have lower costs than most of our major trading compctitors. Their employment costs per manhour are in some cases higher now; their energy costs are higher. We complain about our tax burdens-theirs are by and large greater. We have an enormous amount of flexibility in our industry. We have individual companies of all types and descriptions. We can find people who can do a job in most any type of business arrangement, any sort of business structure, any sort of concept. Finally, we have potentially a much larger home market for solar than other nations do simply because we are a larger aggregation of people and have a more favorable physical climate than do most of our major competitors.

We receive much less marketing assistance from our government than foreign companies receive from their governments. I know there are some problems-structural problems associated with export assistance-but I prefer not to debate those problems at this point in time. We receive, for all practical purposes, no subsidies from our government for exports in one manner or another. Foreign governments characteristically subsidize the exports of their industry. To some extent the traditional U.S. industry attitude has been rather lackadaisical as far as foreign trade is concerned. Possessed of a quite large domestic market, many of us plainly ignore foreign potentials. What we must do, not only in the solar industries but perhaps in the other industries as well, is to develop new and innovative means to make us competitive with subsidized foreign industry in foreign markets in coopcration with the federal government. This is a major challenge that the industry and governmental partnership in this area must face. Part of the challenge is 
how to accomplish this objective within the framework of our own indigenous, unique system of free, competitive, and privately-owned industry. We certainly do not want to sacrifice that in order to compete more effectively in foreign markets. We have to develop innovative methods which differ from those of the French and Japanese. Such methods would preserve that aspect of our industry and other industry as well, while still providing us with the means to become competitive in the international market.

Because of the newness of our particular industry, the solar industry, and our association, we are prepared to work with you in the development of innovative solutions tc problems. We have not been around long enough to have any traditions to speak of. Indeed in some other areas, SEIA and Solar Energy Research and Education Foundation (SEREF)-our sister organization-have undertaken and successfully implementec innovative approaches to government-industry and industry-consumer relationships. I think we can point with some pride to our track record in doing things that are new; different, and innovative in terms of industry programs and industry thinking. We wan1 to join with you in facing the challenges of doing something constructive. If we succeed: because of the advantages that we have at present, we in the solar industries and the United States as a nation can be the dominant factor in the international solar trade. If we fail, Japan Incorporated, France, Germany and other countries as well will take the business as they have done in other business areas. But we do not need to fail. We have some very important advantages and we need to cooperate to do something about them. 
Session I

U.S. Government Overview 


\section{OVERVIEW:- TDEPARTMENT OF ENERGY}

Nilliam Corcoran

Department of Energy, Office of Conservation and Solar Applications.

Before we get started in Session One, I would like to comment on a couple of questions raised earlier. With respect to some of the commercialization activities within the Department of Energy (DOE), there are several plans that are underway now which will feed into a general national plan for the acceleration of the commercialization of solar. A great many of these commercialization plans actually have assigned resource managers. They are the advocates for those particular programs, which currently include hot water, passive, industrial process heat, photovoltaics, wood, and wind. All these are primarily domestic right now, but we are heading for the international planning activities, and this is what you will hear a great deal about today. Now we are going to provide an overview of the U.S. government interests and activities in stimulating greater worldwide use of renewable energy resources. These include both the technologies that are ready for the marketplace and those where cooperative $R \& D$ are mutually beneficial: solar thermal systems, photovoltaics, wind energy conversion, biomass, ocean thermal, and lowhead hydro.

With me this morning on the panel are some very important gentlemen from several agencies within the government: Dr. Jack Vanderryn, our Director of International Programs at DOE; Martin Prochnik from DOS; Richard Garnitz from DOC; Sam Boskin, and Steve Klein from AID; and John Bierman from the Ex/Im Bank. Although not represented on the panel, the Department of Agriculture Action/Peace Corps and the International Communication Agency are also involved in our activities within the ISCWG.

I would like to take a few_minutes to tell you about DOE. The-international activities within DOE-can be grouped into three major thrust areas indicated earlier: commercialization, technical cooperation,_and_cooperation with developing countries. The first is commercialization which is the bridging of the gap between research and development and a commercially viable product or system. What DOE seeks to do is to accelerate worldwide commercialization and use of solar energy systems and technologies, to encourage the volume of export markets for U.S. renewable industry, and to establish a more economically viable domestic market. Our strategy to achieve these objectives is to identify through market surveys conducted with the cooperation of DOC the most attractive foreign markets for U.S. solar products and services. We want to involve you, the U.S. industry, and other government agencies in cooperative efforts that accelerate commercialization and export of U.S. solar products and services. We want to conduct joint venture programs between U.S. participants and cooperative countries that should both expand/create the market for U.S. solar products and also build a capability within the market country. Export aids and incentives which will be discussed by John Bierman from the Export/Import Bank are important to the success of

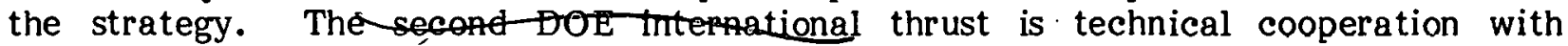
developed and upper income developing countries. This cooperation is in $R \& D$ and technology demonstrations, and is through multilateral and bilateral agreements that Marty Prochnik from DOS will describe to you. This technical cooperation with other industrialized nations, developing countries, and international organizations is aimed at the development of new and improved solar technologies suited for use in the United States and/or abroad in cooperation with developing nations to support the beneficial uses of solar energy. The third DOE international thrust is cooperation with-devetoping 
countries, particularly those who need assistance. These activities include resourc assessment, analysis of needs, appropriate technology $R \& D$, technology demonstrations and training. We do this in cooperation with AID. As Dick Garnitz from the DOC wi] discuss, cooperative programs are aimed at bringing about optimum energy resource involvement only with the help of appropriate international, financial, and technica assistance. 


\section{SCOPE OF FEDERAL INTEREST}

- DEPARTMENT OF ENERGY - POLICY PLANNING SUPPORT AND PROGRAM IMPLEMENTATION

- DEPARTMENT OF STATE - OVERALL POLICY AND GUIDANCE

- DEPARTMENT OF COMMERCE - GLOBAL MARKET SURVEY AND DEVELOPMENT

- AGENCY FOR INTERNATIONAL DEVELOPMENT - FOREIGN ASSISTANCE

- ACTION/PEACE CORPS - ASSISTANCE TO DEVELOPING COUNTRIES

- INTERNATIONAL COMMUNICATIONS AGENCY - INFORMATION TRANSFER

- USDA - AGRICULTURAL AND INDUSTRIAL PROCESS HEAT

- EXIM BANK - FINANCIAL ASSISTANCE 


\section{MULTI-NATION ORGANIZATIONS}

- OECD/INTERNATIONAL ENERGY AGENCY (INDUSTRIALIZED COUNTRIES COOPERATION)

- NATO/COMMITTEE ON CHALLENGES OF MODERN SOCIETY (DATA ECXHANGE)

- WORLD BANK (MONETARY ASSISTANCE)

- UN (TECHNOLOGY TRANSFER)

- OTHERS 


\section{DEPARTMENT OF ENERGY'S INTERNATIONAL SOLAR ENERGY ROLE}

COMMERCIALIZATION

- MARKET SURVEYS/ASSESSMENTS (WITH DOE)

- TECHNOLOGY/PRODUCT DEVELOPMENT FOR FOREIGN APPLICATIONS

- PROMOTION OF U.S. TECHNOLOGIES/PRODUCTS IN COOPERATION WITH U.S. INDUSTRY

- GOVERNMENT STIMULATION OF EXPORTS

TECHNICAL COOPERATION

- RESEARCH AND DEVELOPMENT FOR MUTUAL BENEFIT

- TECHNOLOGY DEMONSTRATION PROJECTS

COOPERATION WITH DEVELOPING COUNTRIES

- RESOURCE SURVEYS/ASSESSMENTS

- APPROPRIATE TECHNOLOGY DEVELOPMENT

- TECHNOLOGY DEMONSTRATION PROJECTS

- TRAINING 
THIS PAGE INTENTIONALLY LEFT BLANK 


\section{ACTIVITIES OF THE DEPARMENT OF STATE}

Martin Prochnik*

Deputy Director for Energy and

Safeguard Technologies

Department of State

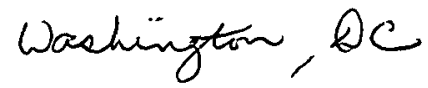

I would like to explain roughly what DOS is charged with doing and then to go into more specifics that have a direct relationship to your area of interest. In general terms, DOS is responsible for our foreign relations-and-our-associations-with_other countries. DOS acts as an intermediary for federal agencies, the public, and the elements of-Congress who are concerned with international issues. Of greatest priority to us are those relationships that have some sort of bearing on our national security, both military and economic, and those programs and activities that are supportive of U.S. industry and the U.S. public-at-large. I will illustrate with examples touching on solar technology. One of the principle issues of concern to the administration is nonproliferation. The President, the Congress, and the public at large are worried about the possible spread of nuclear explosive capability and a number of programs and activities are underway that are designed to discourage the spread of this capability. Energy technology cooperation with other countries of the world can demonstrate both to specific countries with which we deal and to the world at large that there are alternatives to nuclear. Such alternatives may not only make more sense from a national security viewpoint but also in the long run make more sense economically and from the resource perspective. Solar obviously falls in the category of having a long-term, strong impact on this kind of an objective or goal and one that has been specifically recognized by the President. Sarah Jackson discussed the effect, in economic terms, that oil prices and security of supply issues have had on this country. As she noted, we may have that driven home to us by the events now taking place in Iran. Energy cooperation, and specifically energy technology cooperation with other countries, will have an impact on the need of the industrialized world, and the developing countries as well, to import their oil and gas supplies from sources that may not be very secure. Finally, again in very general terms, we are interested in maintaining overall good relations with other countries. Very of ten the decisions these countries make in cultural, commercial, and economic areas depend on our overall links and whether they are positive or negative. Overseas buyers of technologies may very well have their decisions influenced on a personal and governmental level by whether these countries think the United States happens to be wearing a white or black hat at the moment. In sum, the state of our overall ties have a relationship, although it is an indirect one.

I would like to discuss U.S. multilateral and bilateral programs. Again, as Ms. Jackson pointed out earlier, the IEA is the focus for our multilateral cooperation with other countries. We like to see one organization as the focus not only because it serves to

* Martin Prochnik is the Deputy Director for energy and safeguard technologies within DOS. He began his professional career as a geologist with the AEC, has been a foreign service officer in Canada and Latin America. He has served with the National Science Foundation, and the Department of Interior. He graduated from Harvard and Boston University and his area of expertise las moved from geology to energy technology. 
concentrate the efforts of a number of countries at one point, but also because it avoids unnecessary and duplicative travel of U.S. experts whose services are also needed a home. The NATO/CCMS effort, mentioned this morning, began its activities with \& number of solar projects which are now being phased out. The continuing activities which remain are information exchange programs in which a number of countries have agreed to exchange data about their national activities. Ms. Jackson also mentioned that at the last economic summit meeting, which took place in Bonn last June, there was agreement on the part of the leading western industrialized countries to help the developing countries in energy matters in general and to try and construct a renewable energy program which would serve to assist the developing world in applying renewable technologies-at an early moment. We have a number of bilateral activities, the most important of which is the U.S./Saudi cooperation, which resulted from an initiative on the Saudi side to contribute $\$ 50$ million over a five-year period if the United States were willing and able to come up with a matching sum to contribute to the development of solar energy. The Saudis were very general in their invitation for collaboration, and the process of trying to pin down exactly what we might do with Saudi Arabia is still underway. We also have a program with Brazil in which solar plays a prominent part; as some of you familiar with bioconversion know, the emphasis there is on the production of alcohol from biomass. There are energy components to our overall energy cooperation with the Soviet Union and Japan. Our efforts with the Soviet Union in solar have not been as active as we might have liked. Our energy cooperation with Japan received a recent boost by an offer of the Japanese Prime Minister to greatly enlarge our bilateral cooperation in energy technology development. He specifically singled out solar energy as having the most to contribute to the resolution of our long-term set of energy problems.

I would like to answer one point raised earlier by a gentlemen who asked a question. He did not really see in all this talk about energy cooperation how this would really contribute to the sales of American technology or equipment overseas. Well, there is a direct relationship. We have found in several case histories we have studied that where two countries get together to jointly work in the development of a technology, very of ten the framework is set and the people-to-people contacts are established which may very well lead to commercial sales later on. But admittedly, the direct cost/effect relationship is a little hard to pin down. 


\section{ACTIVITIES OF THE DEPARTMENT OF COMMERCE}

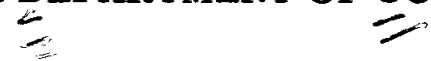

Richard Garnitz, Director*

Department of Commerce, Office of International Marketing

Wachungtoi, QC

I represent the "crass commercial side" of the program. I will admit I know little or nothing about solar energy, though I am beginning to learn more just by listening to people at dinner last night and to this conversation. I am here because there is going to be another $\$ 30$ billion deficit in our balance of trade this year because the actual value of exports of American-made goods in constant dollars has not increased since 1974. In 1974 , we sold $\$ 56.1$ billion manufactured goods; in 1977 , we sold $\$ 56.7$ billion of manufactured goods. So we have a problem. Only $12 \%$ of U.S. manufacturers are doing any exporting. There are somewhere between 18,000 and 20,000 U.S. manufacturers who are export-capable who export nothing or nowhere near their capability. We are interested in assisting U.S. manufacturers of any equipment with selling their products abroad. We are particularly interested, of course, in new industries and where U.S. manufacturers can develop new markets. We are anxious to help where we can. We have the expertise and we believe the knowledge available to assist any U.S. manufacturer in identifying markets, reaching the individual customer agency or business partner, and selling the product. In light of this, we are one of the many agencies which have an agreement with DOE to assist them in sponsoring on events abroad to help the businessmen and.manufacturers to sell those products. We recently signed an agreement with the commercialization part of DOE, and I guess that goes for the whole Department, to do this type of thing.

There are many things that we can do and I would like to go over some of them. One of the first things we do is try to get somebody in our organization that is knowledgeable about the industries we work with. With me here today is Mrs. Janet Thomas, who is the most knowledgeable person in our organization on solar energy equipment. We begin with our own research which is based on purely commercial questions. Are the products saleable? Where are they saleable? How do you enter those markets? What are the barriers? How can we assist you? What are the distribution systems? What is the stateof-the-art in those countries from a commercial point of view? We are developing a global market survey on energy equipment. (Not strictly on solar, but on energy saving equipment in general.) A global market survey is put out (approximately 5 to 7 ) each year, and we have some 35 or 40 which are always current. These take an American product or industry and look at it from the perspective of the 50 to 20 best markets for this product around the world. These come from DOC; they are available to you directly from the Department or through the DOC field office closest to your factory or office.

\footnotetext{
* Richard Garnitz began his career back in 1963 with some trade mission programs. He had been formerly a Vice President and General Manager of a consumer-oriented business in Indiana. In 1967, he became the Director of the U.S. Trade Center in Tokyo. In 1969, he was a Commercial Attache in our Embassy in Stockholm and Director of U.S. Trade Center in Scandinavia for DOC. Then in 1972, he was a Deputy Director for International Marketing. From August of 1975 to March of 1976, he was also the Director of the Ohio State Columbia University Foreign Service Institute.
} 
Based on the research that we do and the input we get from the government institutions such as DOE, we do two things. We develop an active program on our own to help you sell these products, and we try to make ourselves available for assistance if you decide you would like to do something on your own or to give you some evaluation of what you feel are your commercial possibilities abroad. For instance, based on our own research and the input from the experts in DOE, DOC, and the foreign service abroad, we have scheduled large exhibits. (In March of next year, a big one will be held at the U.S. Trade Center in Milan which will attract buyers from all of the Mediterranean Basin countries.) We have a solar energy alternates exhibition at our international marketing center in Paris in September of 1980. We have an industrial energy management exhibition in the Trade Center in Mexico City in April of 1980.

We have developed these exhibits based on our own research and the research done by DOE. These exhibits are based on research indicating there is a market for your products. We call upon our staff to identify by name every perspective customer, agent, and business partner in the marketing area. Each of these people are contacted individually at least three times. The key people, perhaps $10 \%$ of the total (ranging anywhere from 5 to 50,000 people depending on the market and the product) are visited personally and enticed, seduced, kidnapped, and brought to the show for you to see, meet, and talk to. We do the same thing for these exhibits. We of ten send out trade missions. I talked to a gentleman who has served on several of our trade missions made up of members from an industry. We do research and pre-identify the people that you should be talking to. We set up the appointments, the place, and try to assist you in selling. All you have to do is bring yourself, your equipment, and your ability to sell that equipment. We guarantee you that you will be talking to the people who are interested in buying.

We want to help any firm individually, too. This is where we get into the reactive assistance that we can do for you. Any individual who walks into our offices in Washington or in any DOC field office, and says "I believe my product is exportable and Im interested in exporting it-where, to, and how?" we will help on an individual basis. We will take that description of that product, go out to our network of people around the world (the commercial attaches and embassies), our own people, and Commerce people in the trade centers, and we will get some desk study view of the saleability of that individual product. Based on the information that comes back, we will prepare for you a - minor marketing plan which will put your markets in order in priority with the backgrounds of each of those markets. What are the possibilities of selling your particular product? What are the social, moral, and legal barriers to selling your product in that country? What is the distribution system? And how we can help you actually enter those markets. We will do that for any individual company that wants that. We will be more detailed and give more assistance to the medium-and small-size company in this way than to the large ones on the basis, of course, that the large ones have much of their own installations abroad. We feel that we must give more to the small companies, and particularly the new products.

Any new product that has never been put on the market before, at no cost to the individual company, can be included in our Commercial News which goes abroad to some 60 countries. Commercial News is sent free to a minimum of 2,000 firms so a new product receives worldwide coverage. We take a picture of it, and print a description free of charge. Relationships have been started and then the next step is a trade mission or a trade fair to actually go sell these things. Participation in the trade fair or mission 
does cost, but not much. In fact we have a continuing fight with another part of the government-OMB-which is not quite as cooperative as to how much and whether or not we should charge you.

In addition, if you have particular interest in a single country, and you feel that there is a market for your product, we have what are called Country Marketing Managers. From a commercial activities standpoint, these are the most knowledgeable people in the government on their ability to sell products, and you are welcome at anytime to sit down with them. They will go into detail on whether there is a market for that product in their country; and how you go about entering into it. Basically, that is what we can and want to do for you. 
THIS PAGE INTENTIONALLY LEFT BLANK 


\section{OVERVIEW OF THE ACTTVITES OF THE EXPORT-IMPORT BANK}

John Bierman, Senior Vice President*

Export-Import Bank of the United States

washengtin, Dc

The Ex/Im Bank is very pleased to take part in the Solar Export Opportunities Workshop. Ex/Im Bank has not played an active role in your industry. One reason is our lack of familiarity with your particular industry and its export financing needs. The solar industry and renewable energy in general was brought to our attention in the last legislative section when Senator Percy introduced an amendment to the Export-Import Bank Act, which required the Bank to designate an officer who would advise our President and the Congress on what we are doing for the renewable energy industry and how we might better serve that industry. We had never really looked at the solar energy or other renewable energy fields as an active industry for Ex/Im Bank assistance, but because of the legislation our Board designated me as the Bank's Solar officer and asked me to start working with Bill and others at DOE in order to come up with programs and incentives which would allow us to support your industry more actively.

Also, I believe one of the other reasons that Ex/Im Bank has not been of particular use to you in the past is because to your industry we are probably the best-kept secret in Washington. You are all very familiar with DOE, DOC, DOS, and AID, but you are probably very unclear about the function of the Ex/Im Bank and how it may be able to assist you. Over the two days, my colleague Frank Wilson and I would like to familiarize you with the Ex/Im Bank and at the same time hopefully become more familiar ourselves with your industry's particular export needs. This morning I will explain how the programs of Ex/Im Bank may be used by your industry in support of its export efforts. Again, since most of you may not be very familiar with it, I will briefly describe the Bank, the institution, and then in the most general sense, the programs.

We are a small independent agency of the U.S. Government with about 400 people all quartered in Washington, D.C. We are governed by a five-person Board of Directors. Unlike most Boards, it is full-time, appointed by the President and confirmed by the Senate. Instead of working a 40-hour week, our Board probably works 60 to 70 hours a week on Ex/Im Bank business. It is a very diverse board. Our chairman is a lawyer from the city we are located in (Atlanta); our Vice Chairman is a small-town banker from Texas, (if there is a small-town banker in Texas); and we have three other board members. One is a former head of a major U.S. corporation; one is a small business person; and the third was an investment banker and lawyer in one of the New York

*Before joining the Ex/Im Bank, John Bierman was with the Rural Electrification Administration, and U.S. Department of Agriculture. He was the Deputy Vice President, Exporter Credits and Guarantees at Ex/Im Bank until 1972. His current duties and responsibilities encompass the administration of the Commercial Bank Exporter Guarantee, the FCIA insurance, Cooperative Financing Facility, and Discount Loan and Claims programs. Additionally, Mr. Bierman is the Bank's small business liaison officer, the Bank's alternate representative on the Intergovernmental Minority Council, and the Bank's alternate representative on the Board of Directors of the Foreign Credit Insurance Association. Currently, he is Ex/Im Bank's Senior Vice President, Exporters Credit, Guarantees, and Insurance. 
investment banking firms.

Throughout our 45-year history, our function has been to finance and facilitate the export trade of the United States. I stress United States here because as a U.S. government agency our support is limited to the export of U.S. goods and U.S. services. We achieve our goal of facilitating exports through a combination of direct loan, loan guarantee, and insurance programs designed to overcome the unwillingness of the private financial community to provide the needed export financing services for U.S. products and services. As an example of the size of business done in a particular year; during FY78 which ended last September 30, the Bank supported between $\$ 10$ and $\$ 11$ billion in U.S. exports from the United States. We have been accused of being a "big boys" bank as much of our support and most of our notoriety comes from the export of commercial aircraft, nuclear power plants, steel mills, and other major product or project procurements. Of that $\$ 10$ or $\$ 11$ billion in export sales, $60 \%$ of it by dollar volume and $95 \%$ by numbers of applications took place in what we call our short- and medium-term export support programs; where the median size sale is $\$ 150$ to $\$ 175$ thousand; where the average term may go up to 180 days or 270 days or if you get into the medium-term end on capital equipment, up to three to five years. The majority of the Bank's business therefore, comes in supporting relatively small export transactions of all sizes, natures, and types of equipment. Nearly everything exported from the United States from cocktail napkins to nuclear power plants has been supported by the Ex/Im Bank.

We are a self-sustaining agency; we receive no appropriations from the U.S. Congress, although we are accountable to both the President and the Congress, and to the OMB for our budget. We are one of the few government agencies that make money. My salary and the travel expenses for this trip are paid for out of the earnings received from the interest charged on our loans and from the premiums charged on our guarantees and insurance. We are a stock corporation. In 1945, $\$ 1$ billion of stock was issued by the Treasury to set up and establish the Ex/Im Bank. We have repaid just over $\$ 1$ billion in dividends to the Treasury on that initial stock issue; we have now $\$ 1.9$ billion in reserves along with the initial $\$ 1$ billion in capitalization. So we have been very profitable and have never gone to the Congress for appropriations.

We are not a grant or a development aid institution either for the foreign buyer or the U.S. exporter. We must determine in every transaction we support that there is a reasonable assurance we are going to get repaid by the foreign buyer and that the repayment term that we are being asked to support is considered customary in the international trade. This is one of the major areas where we divert from AID, the World Bank, and other international institutions. They are geared for development assistance, while we are geared more to the commercial aspects of export trade. Our statute also requires us to consider a wide variety of other factors before we can provide financing assistance for a U.S. export. One factor (and I think the key) is that we are required to encourage and compliment private capital and not compete with it. On our major project loans we loan funds directly to the foreign buyer, but in most cases this is done in participation with private financing. In the short- and medium-term areas, all of the financing takes place privately with our support being in the nature of a guarantee to a U.S. bank or insurance directly to the U.S. exporter. We have to balance this requirement of supplementing and encouraging private capital against the directive to provide our own financing on terms that are competitive with the terms provided by our counterparts abroad (the official export credit agencies of other developed countries) 
Especially in today's times when prime is at $113 / 4 \%$, it is very difficult to encourage private capital and still remain competitive in the international marketplace. We thus have to balance what we do and try to make as much direct funding available from the Ex/Im Bank at as low a rate as possible and then supplement that whenever we can with private financing. We have to consider our cost of funds since we are a self-sustaining agency. We also must take into account any serious impact our support would have on U.S. industry and employment. At one point we had written into our legislation that we had to consult with the Department of State as to human rights considerations on each transaction we supported. The last amendment to our Act changed that requirement somewhat in that it stated if we were to deny any request for assistance for nonfinancial or noneconomic reasons we must get a Presidential determination that it is in the best interest of the United States to turn the business away and that we are not impeding the export efforts of the United States. We still consult closely with the State Department, their human rights people, and the Christopher Group headed by Deputy Secretary Christopher on the human rights aspect of each loan in which we are involved. We also look very closely at environmental issues, nuclear nonproliferation issues, and again, domestic impact.

The current management of Ex/Im Bank sees an important role for us to play in our government's export promotion effort. We are taking an aggressive role in competing more effectively with our counterparts in the other major trading countries and in trying to be imaginative in designing or trying new ways to improve the usefulness of our services.

Again, I reemphasize that while we are committed to being competitive to support an increasing level of U.S. exports, we are not prepared to finance uncreditworthy transactions just to do more business. It does you and us no good if we go ahead and support an export transaction that is a loser. We make our credit judgments by examining the export transactions themselves, the purchaser, and the purchaser's country. Whenever Ex/Im Bank financial assistance is required, we take a look at the financial condition and the prospects of the foreign buyer that we are being asked to support. When our direct loan or financial guarantee is requested for a major project we also look at the feasibility of that project. We have an engineering staff at the Bank, quite astute at project evaluation, which takes a very close look at the technical viability of major projects we support. In addition, we prepare comprehensive evaluations that go to our board on the country to which the export is going.

We have two basic delivery systems by which our programs are generally put forward to the U.S. exporting community and to the foreign buyers. It is impossible for us with our staff of 400 to market, put together financing packages, and administer a portfolio which is now about $\$ 26$ billion in outstanding credits. The two delivery systems we operate through (private systems) are the U.S. and the foreign banking communities, and the insurance industry through the Foreign Credit Insurance Association. Under our project lending program, which is generally limited to export transactions in excess of $\$ 5$ million, we participate with the private banking community in putting together major projects 
abroad where a repayment term is in excess of five years. We participate or share in the financing with the bank. We may guarantee the private bank and we will only put up funds where the private banks do not have the funds or are not willing to have their funds out for the period of time necessary to complete the transaction.

We have a medium-term commercial bank guarantee program. Under this program, an exporter would approach his bank for financing of a medium-term (one to five year) export transaction. If that bank agrees to finance the sale, it would then come to the $\mathrm{Ex} / \mathrm{Im}$ Bank for a guarantee of the political and commercial risks inherent in that transaction. The bank would finance the exporter on a nonrecourse basis so he would be in funds at the time of shipment. If there was a loss because of commercial or political reasons, we would pay out the bank and would try to recover from the foreign buyer. This is the program that many of the local banks have used to get into the export area for the first time.

We also have a program called the "Cooperative Financing Facility" (CFF) where we work through foreign financial institutions. We make a line credit available to a foreign bank for relending to small- and medium-sized buyers in their own country. This has been especially successful in certain of the Latin American markets, Korea, Israel, and a :2: few other developing countries. Unfortunately, this problem is coming under severe $\checkmark$ budgetary problems; we have been cut back substantially in FY80 and FY 81 . While the program will still be viable and we will be able to service lines that are outstanding, there will be no new marketing effort on the CFF going forward. The program still is available in countries such as Brazil, Argentina, etc., and we hope it will be actively used in those markets. This is the program I believe has been most actively used by the small business community in the United States. It allows the foreign bank to work with the U.S. exporter in the buyer's own country to put together a financing package where sufficient credit and financial information may not be available to Ex/Im Bank in order for it to pass on the credit of the particular buyer.

One other program we have which works through the insurance industry is the Export Credit Insurance Program. This is operated and administered by the Foreign Credit Insurance Association (FCIA) which is headquartered in New York and has branches throughout the country. This is the only area in the Ex/Im Bank scheme of things where an exporter can get support for a short-term export sale. Those are the sales on terms up to 180 days. Under this type of operation, we insure a U.S. exporter against political and commercial risk for all of his export sales on a term of up to 180 days. We also have medium-term programs which go into the capital equipment area where an exporter can get coverage on an individual sale basis for pieces of capital equipment sold abroad. The insurance program generally covers commodities, consumable goods, spare parts, raw materials, and it also has a special program to support the export of services. Most of the programs of FCIA are designed for whole turnover, trying to cover under one policy all of the exporter's sales that go forward on commercial terms giving discretionary authority to the exporter so that he can commit FCIA or Ex/Im Bank without having to run his credit through us. We also have special incentives for small business through both the insurance and the medium-term guarantee programs whereby we will increase the percentage of cover for those small businesses which may be using our facilities for the first time, or are new to export. There are other incentives for the small business person through Ex/Im Bank. 
We also have one area of the Bank which might be especially useful to companies that are getting involved with export for the first time: the Credit Information Section. We have an area of the Bank that works closely and maintains records on repayment experience with the thousands of foreign buyers that we have dealt with over the years. In calling our Credit Information Section at the Bank, ask for Bob Camp. Bob can let you know what our experience with a particular buyer has been; how large a credit we have supported to the buyer, whether he is paid on time, etc. This is used effectively by both the banks and exporting community in the United States to give them an indication as to what kind of payer the company is. It is important that you make use of this facility.

The programs mentioned are available for the export of equipment, and also for the export of services and technologies. I believe the insurance program is the most applicable in the export of services. If you are entering into a service contract abroad where you are getting monthly payments for your services, you would probably benefit most under the short-term insurance program. Here we would guarantee or insure that if the foreign buyer did not make payment for defined commercial or political reasons, we would again make you whole and try and effect payment from that foreign entity. If you are performing a service contract or a feasibility study abroad, and upon completion of the study the foreign buyer says that he will pay over a three-year period, we can insure or guarantee the payment by that buyer to you so that if he does not pay, we make you whole and go back against the foreign buyer. In both services and equipment, therefore, we can put you in funds or work with your bank to put you in funds very early on in the game, and we will then take the worry out of being close with the foreign buyers.

We have tried to design programs at the bank for nearly every company's and industry's export needs. I hope your industry will make active use of the programs of the Bank and of FCIA in the future. Anything that I can do to help you, please ask me. We are dedicated to increasing our support of the solar industry and I hope that through conferences such as this we will be able to do more together. 
THIS PAGE INTENTIONALLY LEFT BLANK 


\section{ACTTVTTES OF THE AGENCY FOR INTERNATIONAL DEVELOPMENT

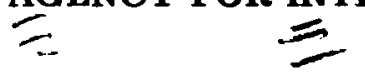

Stephen Klein, Energy Policy Advisor*

Bureau of Policy and Program Coordination

Agency for International Development

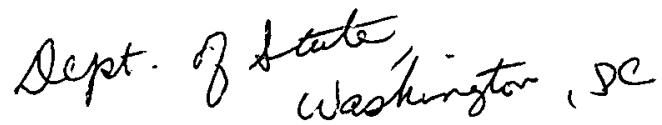

I will try to condense my remarks about some of what AID does in terms of assistance, and stress how foreign assistance programs might be useful to you in the private sector. My comments will describe the increasing recognition of the need in the developing countries for renewable energy; our past and on-going programs; the role and how the private sector interacts with AID; and projects and activities AID is contemplating.

In the last couple of years because of the oil price increases, developing countries are beginning to look seriously at the potential for renewable energy. I think Sarah Jackson mentioned the need for looking at the systems in terms of being economically and technically viable and appropriate to the social context in which they are going to be used. The problem is the lag time before these technologies become cost effective and are demonstrated as effective in developing countries' environments. If a curve for the cost of the existing supplies of energy in developing countries is plotted, it indicates that sometime in the not-too-distant future, there will be a cross-over in applications in developing countries where the cost of conventional energy is high because of high infrastructure costs: we will find that renewable technologies (solar) will be the cost-effective solution. A question for AID to address is whether there are activities that we can undertake now that will hasten the time when developing countries are going to be able to use these systems when they are cost effective.

Oil supply in the developing countries is becoming increasingly limited. We feel the pressure in the United States in terms of some increase of prices, but the problem is radical for developing countries. This has created a new category of countries entitled Most Seriously Affected (MSA) countries on the balance of payment side, because they are using up sizable portions of their foreign exchange for oil. There is no question that the recent increase in OPEC prices is going to hit them even harder.

In addition, these countries face other problems concerning traditional sources of energy, fuelwood, and crop residues. Over half of the people in the world use traditional fuels as their primary couroe of energy. That probably is not going to change too significantly over the next two decades. Fuelwood is running out as a result of the increasing pressures, population, agriculture, production, and other activities of this nature. If you have seen some articles which refer to the other energy crisis, you would know that wood is becoming scarce. All of the developing countries are aware of it, and their planners are having to address it. The people who use wood have previously thought of it as a free good, but it is not. In some countries urban dwellers are using $25 \%$ to $30 \%$ of their income to buy wood for just the regular cooking needs. The point is that people are going to have to look to alternative sources of energy, solar energy in particular. You in the private sector ought to be aware of this, if you are not already.

*Stephen Klein studied his undergraduate work at Cornell University and his graduate studies in finance at the University of Chicago and American University. He has been involved in Domestic Policy Review, Economic Reviews, and Policy Formation for AID. He has had extensive experience in U.S. projects and AID development in Africa for approximately 15 years including energy projects in the last two or three years. 
The United States has been aware of the importance of renewables in decreasing the world dependence on oil and in helping countries achieve their development objectives. One of the primary objectives of AID is to assist countries with renewable energy programs: we are working with DOS and DOE on this initiative. Sarah Jackson earlier referred to the Economic Summit initiative on renewable energy. President Carter joined with the heads of six other Summit countries and made a commitment to elaborate the details of a renewable energy program. The wording of that program says "to help developing countries, we will increase national development assistance programs in renewable energies." We are in the process of elaborating those details which the Summit Communique said we would announce within one year, which will be in May or June (for the Tokyo Summit). The Summit Communique also included encouraging a World Bank program to look at hydrocarbons to expand the availability of conventional energy (which will continue to be the primary source of energy for developing countries).

The fact that the Summit countries are looking at renewables has a lot of significance for you because it means that more money from government resources will be going into this area, both U.S. government as well as other countries. For the U.S. assistance program, we would think that a major share of these funds will be available for the private sector in the normal ways in which AID does business, which I will discuss in just a minute. In addition to the Summit initiative, there is going to be a UN Conference on Science and Technology for Development in August of 1979, at which time there will be a lot of discussion about energy. The UN General Assembly in late December approved a resolution for 1981 Conference on New and Renewable Sources of Energy. The General Assembly debated including nuclear and decided to limit it just to renewables. Again, the important component is the increased interest throughout the world in renewable energy technologies.

How do these activities affect your own opportunities? AID is a development assistance agency, but we normally link our assistance to U.S. exports to the maximum extent practicable. We use technical expertise from the United States, and we finance goods and services that are commercially available. I know that the developing countries themselves look to the United States as the technological leader in this area. In my travels to Africa and other parts of the world, I see the substantial interest in assistance programs that would permit developing countries access to U.S. technology. A challenge for use is to structure our programs in ways that permit the linkage between the expertise available in the United States, and the interest and needs in developing countries. The primary goal of AID in terms of our Congress is to support assistance programs directed towards those poorer elements in developing countries. This is a result of the revision of the AID legislation in 1973. However, I think there is a recognition in the Congress that energy has additional dimensions. Our legislation contains authority not only to finance rural energy related to assistance for the poorer aspects of the society, but also to provide assistance for conventional energy in urbun energy programs. We carry out those activities in our specific bilateral programs.

AID has been evolving its energy program over a period of time to emphasize renewables. The challenge is to help develop systems which are cost competitive, can be maintained, and have low recurrent costs. Here we get into the area of demonstration. (The Senegal discussion is one example.) In addition, we recognize the potential of photovoltaics for pumping and grinding-I was just in India at a UN Conference and saw a real focus on photovoltaics in the Indian planning. The Indians have a very strong interest in U.S. photovoltaic technology because they recognize that the existing expansion of a central power grid will be unable to meet their own development needs from the perspective of cost effectiveness. 
How does a business get involved in an AID program? AID has missions in developing countries, and we sit down with a country to plan specific bilateral programs. Our AID missions will agree with the countries on the areas in which they wish to work out agreements on U.S. assistance. The major share of the funds that AID provides is initiated in this way. I think Dr. Bosken will describe some of the central energy programs. More of those projects are direct contacts with AID where we are more in the research area and identify specific areas. Ordinarily, we do business through public competition, with competitive bidding, and we use a request for proposal system. We are especially sensitive to the need for all aspects of the business community to have an opportunity to compete and most developing countries are interested in assessing the best that the U.S. private sector has to offer.

We see a need for a demonstration activity. We are now wrestling with how to structure our assistance programs to demonstrate some of the renewable technologies. This gets back to what I mentioned earlier about the need for demonstrating technologies in place in developing countries in order to move them to a place where they will be financially viable. I know Ex/Im people will be very pleased when the technologies get to the cost-competitive perspective.

AID has four regional bureaus. These include Africa, Near East, Asia, Latin America, and the Caribbean as well as a central bureau in Washington (the Development Support Bureau). We operate on a fairly decentralized basis in which our missions in each of these parts of the world are in contact with the four regional bureaus in AID/W and programs are approved with the regional bureaus. We have recently decentralized project authority to the mission director level. Our mission directors have authority for approval of projects for up to $\$ 5$ million without specific approval reference to Washington. There are many projects which the more enterprising among you can develop consistent with our own missions program overseas, which will be approved by them.

The level of AID programs has been at about $\$ 18$ million in FY78 in renewable energy projects. The major project is in the Philippines where an $\$ 8.6$ million loan and grant including a range of projects is now in the implementation stage. There will be some specific RFPs and competitive notices coming out which you should see. I suggest you write to the Philippines if you are interested in this project. We have proceeded with a fairly major project in Mali and a project in Senegal with Thermal Electron financed with the French. We also have financed planning and project identification activities.

In the future, we will have major programs in Asia and Latin America as well as our other supporting assistance in the Near East Bureau. Congress is very interested in renewable energies and I think there is high interest in these programs across the board in the U.S. government. We are expanding the level of programs in the range of $\$ 40$ to $\$ 50$ million for FY80 depending on funding availabilities and the 1980 presidential decisions on the level of budget. There is no question that AID will be the major U.S. government source of financing for renewable energy projects installed in developing countries. There are real opportunities available here. Our interest is to assist the developing countries, but that assistance merges with the U.S. private sector capability in providing the best technology that we have to offer. I can assure you on the basis of discussions that I have had with developing countries, that most of them are actively interested in the U.S. technology. The challenge we have is now we can work out bridging arrangements to get you into this overseas business. 
THIS PAGE INTENTIONALLY LEFT BLANK 


\section{ACTIVTTIES OF THE AGENCY \\ FOR INTERNATIONAL DEVELOPMENT \\ $\therefore$ \\ 三}

Jerome Bosken*

Agency for International Development, Office of Energy

washirtan, ec

It is highly appropriate that we discuss the potential for the export of U.S. technology to developing countries here in Atlanta. This city offers perhaps a premiere example of the ability of U.S. industry to produce a product that satisfies an international need with particular use in developing countries: Coca-Cola. There are many reasons for the wide acceptance of Coke in developing countries. One is taste. Another, however, is CocaCola's use of local labor, materials, and institutions for distributing their product overseas. It is very important to use the indigenous capability of that country to its maximum extent.

Let me briefly describe what AID is and the economic and energy differences between the developing countries as a whole and the United States.

AID manages the U.S. foreign assistance program conducted under the guidance of the Department of State. There are four main concerns of this program: the national security of the United States; the broader diplomatic goal of maintaining good relations with other countries; the economic development of the world as a whole and the maintenance of a strong U.S. economy; and humanitarian concerns based upon the unwillingness of the American people and the American government to accept worldwide poverty.

Before I discuss the AID program, let me present some statistical differences between the United States and developing countries. There are approximately 100 countries that are loosely called developing countries. Population of these countries is about 3 billion people; the total gross product of these countries is about $\$ 1$ trillion. In comparison, the industrialized countries have an economic strength of about $\$ 4$ trillion dollars, with the I.S., ernnnmy of $\$ 2$ trillion.

One measure of the amount of energy used by these countries is the quantity of imported oil. It is useful to compare the magnitude of the oil imported into these countries to that imported by the United States and to the amount of total oil use in the United States. The oil-importing developing countries import roughly $2.8 \mathrm{million}$ barrels of oil a day and use 4 million barrels a day. In contrast, the United States imports 8 million barrels and uses 18 million barrels a day. Since oil is the primary energy source of the developing countries (unlike the United States), the total energy consumed in developing countries is not great.

*Dr. Bosken is responsible for program development in the AID Office of Energy. He received his doctorate in physics from Purdue and he has taught and developed science curricula in Peru. He performed long-range planning for the chief of staff of the U.S. Air Force. He has taught at the University of Wisconsin. Dr. Bosken was previously with AID's Office of Science and Technology with responsibility for its initial efforts in the renewable energy area. He transferred to his current position when it was created in March 1978. 
AID is frequently described as a rural development agency interested in the rural poor. There is some truth to that characterization but there are many reasons for it. The philosophy of development has evolved over the last 30 years. Current thinking, adhered to by the U.S. government and all development agencies in the world, is that rural development is an essential component of overall national development. There are several reasons for this. A fundamental problem faced by developing countries is that the 3 billion people in these countries will swell to perhaps 5 billion people within the next 25 years. That is an awful lot of mouths to feed. How will they be fed? They will be fed if they can increase their own production of food. This will require technical and financial assistance from the developed world which is one reason for AID's concentration on rural development.

Another reason is the question of economic system dynamics. When you are poor and you get more money, you buy food. If food production is not increased, the result of economic growth is that the price of the limited amount of food available increases. To keep the price of food reasonably low, the production of food must increase. Thus as poor people get more money, that money can flow into the agricultural sector of the economy; agricultural production will rise; and economic development will take place. On the other hand, if development assistance concentrates on industrial development, money tends to go to the richer segment of the population, which possesses the capital needed for industrial investment. Their increased income tends to be invested not internally to buy, for example, food, but externally, outside the country. So frequently the economic development of the country is not enhanced.

A third reason for concentration of rural development is to provide a counter for the rapid urbanization in developing countries. For example, perhaps $60 \%$ of the people in Latin America are urbanized and expectations are that by the end of the century the figure will rise to $80 \%$. A much greater burden is placed on the entire social structure when people leave the countryside and come into the city. This burden goes beyond the decreasing ability of the country to produce food needed by the people in the city and results in, among others, increased energy consumption. To stem this urban migration, eff orts have been focused on rural development.

The history of the AID program is comprised of three separate stages. The initial days of foreign assistance to developing countries stressed the growth of Gross National Product (GNP) in the country. Industrial growth was emphasized. Assistance to South Korea, Taiwan, and Brazil was instrumental in their economic development. It became evident in the 1960s that this philosophy was not sufficient, that most of the rest of the world was not developing in an appropriate fashion. Therefore, the emphasis began to swing to rural development and to direct assistance to poor people. In the last several years there has been another change in the philosophy of development assistance. "Growth with equity" is the phrase frequently used to describe the desire to achieve both economic growth and equitable distribution on the income resulting from that growth.

The specific interest of most of the people at this meeting is to develop markets for U.S. products in the developing countries. In that context, I think it is important to bear in mind that there are four elements of a market. First, a potential buyer must wish to purchase a good or service; he has a "need." Second, a potential provider of a good or service must be present. Third, a medium of exchange must exist between the provider and the purchaser; i.e., money. Fourth, an organization must exist that enables the purchaser and the supplier to get together to effect the exchange. In developing countries there is a great need and the U.S. manufacturers are potential suppliers. However, in general, both money and organization are lacking. A country with an annual 
per capita income of $\$ 250$ simply does not have the money necessary to purchase any products. The set of oil-importing developing countries, which as a group import 2.8 million barrels of oil a day, do not as a group have much money left to spend on more energy imports.

That introduction is a capsule view of energy and development. Let me be more specific now and talk about the activities of our central Office of Energy in AID. As a decentralized agency, most of AID's money is spent by the field offices of the regional bureaus. Washington-based programs are meant to be innovative programs to provide leadership for the agency in selected technical areas. The Office of Energy has such a program. The Office was created in March 1978 and we have spent much of the time since its creation in developing our staff and programs, and preparing our budget. For FY79 we have a budget of $\$ 8$ million and anticipate $\$ 13$ million for FY80.

The program of the office encompasses five separate goals. The overriding purpose is to provide field support and innovative leadership to the field missions. Within that purpose the five program goals are: to conduct important studies needed for program and policy development, to manage technology application and adaptation activities, to provide technical services of U.S. agencies to the field missions, to develop small-scale energy activities utilizing private voluntary groups and the Peace Corps, and finally, to develop institutional ability in energy planning and energy technologies.

The studies for program and policy development will encompass surveys for rural energy needs, investigations into the energy implications of increasing urbanization in developing countries, and analyses of the potential of energy conservation techniques. Technology application and adaptation will stress biomass, small hydropower, and direct solar technology with a particular concentration on photovoltaics. Technical expertise of U.S. government agencies, in particular DOE and USGS, will be provided to the field missions. This activity will include consultive work in the field of conventional energy. Small-scale energy activities are very manpower-intensive. Demonstrations of these small-scale devices are best done by people who are living in-country with full appreciation of the energy needs of that country. Private voluntary groups (CARE, various relief services, educational networks) and the Peace Corps are ideal implementors of the smallscale appropriate energy technology program. Institutional development will emphasize energy analysis, planning, and policy formulation on one hand, and technical training in specific energy technologies on the other.

Let me discuss in more detail the office program in the technology adaptation and application area. The concentration on biomass is due to the fact that currently about $50 \%$ of the energy needs of developing countries are currently being met by biomass energy resources. Unfortunately these resources are not being renewed and global deforestation is occurring as a result. Two separate kinds of biomass programs are necessary for AID. Village wood lots and reforestation efforts are needed to restabilize the environmental system in developing countries and to assure that the energy needed for subsistence is available to rural populations. Biomass projects that provide the incremental amounts of energy needed for development, in particular for electrification, will also be undertaken.

Small hydropower is another way of providing the electricity needed by developing countries. The problem with classical rural electrification is that widespread distribution of the electrical load in rural areas does not justify the construction of a transmission line from a central generation facility out to the rural areas to provide the needed power. Use of decentralized sources to provide electrical power in the countryside would 
lower the cost of electrification. Small hydropower technology is a proven technology; it is not being used extensively in developing countries, however, because of a lack of familiarity on the part of development planners with the technology. By reintroducing the advantages of small hydropower to development planners, we hope to generate a greater utilization of this resource.

Regarding direct solar technology, we will be concentrating on the use of photovoltaics. The cost of electricity can get quite high in developing countries. In the capital cities, electricity is sometimes 12 or 15 cents per kilowatt hour. In rural areas that cost goes up to 50,60, or 70 cents per kilowatt hour. In extreme cases the cost is as high as $\$ 1.00$ or $\$ 1.25$ per kilowatt hour. Only limited amounts of electricity are purchased at this high unit cost.

Photovoltaics are an ideal technology to provide small amounts of power for applications that warrant a high unit cost. Our of fice is currently conducting a project in Upper Volta that will prove the technical feasibility of the use of photovoltaics in remote areas of developing countries by people with limited technical training. In a village in Upper Volta we are providing a small array (less than 3 kilowatts) to pump water for the village and grind grain. This demonstration will prove the technical feasibility of the technology. Our next approach will be to apply photovoltaics to selected applications and to develop modular systems to meet those applications. The first application will be rural medical posts, others will be identified at a later date. These subsequent applications will include lighting of educational institutions, water pumping, and communications.

The agency's renewable energy program has increased from $\$ 18$ million in 1978 and is expected to be about $\$ 45$ million in 1980 . The total energy program of the agency is much larger than that. Although it varies from year to year, the program is about $\$ 200$ million a year, most of that in electrification. There has been increasing concern on the part of Congress that electrification, in particular rural electrification, is too costly to be a valuable development tool. The office program hopes to show that renewable energy resources can provide electricity in the countryside and by so doing we hope to see a gradual shift of emphasis from the conventional approach of electrification to the use of indigenous renewable resources to provide electric power in rural areas.

It is appropriate to end by returning to the concept of organization. One important element in renewable energy programs in rural areas is that by nature you are talking about decentralized energy systems. This implies that a large number of people will be required to operate, install, and maintain the many separate systems. The lack of trained manpower is a critical characteristic of developing countries. A lot of AID's activities have been in the field of manpower development, creation of co-ops, and technical and managerial assistance to other mechanisms that are needed for financing and operating local development activities. As AID increases its emphasis on renewable energy systems, it will also be increasing its programs of manpower and institutional development to operate the system. 
Session II

DOE Current Activities/ Status Reports 
Overview of DOE

Solar Cooperative International Arrangements

Presented by

Jack Vanderry

DOE/IA

Dept. of Energy, Worth $D C$ 


\title{
DOE SOLAR INTERNATIONAL COOPERATION
}

\author{
CONSISTS OF
}

I. MULTILATERAL COOPERATION:

COMMITTEE FOR THE CHALLENGES TO MODERN SOCIETY (CCMS) INTERNATIONAL ENERGY AGENCY (IEA)

II. BILATERAL COOPERATION SAUDI ARABIA SPAIN USSR FRANCE 


\section{CCMS SOLAR ENERGY PILOT STUDY}

INITIATED: $\quad$ FALL OF 1973. MEMORANDUM OF UNDERSTANDING BECAME EFFECTIVE JULY 1, 1975.

PARTICIPANTS: AUSTRALIA, BELGIUM, CANADA, DENMARK, FRANCE, FEDERAL REPUBLIC OF GERMANY (FRG), GREECE, ISRAEL, ITALY, JAMAICA, NETHERLANDS, NEW ZEALAND, SPAIN, UNITED KINGDOM (U.K.), AND THE UNITED STATES (U.S.). EIGHT ADDITIONAL COUNTRIES, PLUS THE EUROPEAN COMMISSION, PARTICIPATE AS OBSERVERS.

OBJECTIVE: ENCOURAGE THE COST-EFFECTIVE AND P.RACTICAL APPLICATION OF SOLAR ENERGY TO HEATING AND COOLING IN RESIDENTIAL, COMMERCIAL, INDUSTRIAL, AGRICULTURAL, AND PUBLIC BUILDINGS.

SCOPE:

THIS AGREEMENT CALLS FOR WORK IN THE FOLLOWING AREAS:

- EXCHANGE OF INFORMATION ON NATIONAL SOLAR HEATING AND COOLING PROGRAMS, AND

- EXCHANGE OF INFORMATION ON SOLAR SYSTEM AND SUBSYSTEM PERFORMANCE 


\section{IEA SOLAR PROGRAM}

NINETEEN COUNTRIES INVOLVED

U.S. CONTRIBUTION: $\$ \mathbf{7 2 9 , 0 0 0}$

SEVEN PROJECTS:

SOLAR HEATING AND COOLING

WIND ENERGY CONVERSION SYSTEMS

LARGE SCALE WIND ENERGY CONVERSION SYSTEMS

SMALL SOLAR POWER AGREEMENTS

FORESTRY ENERGY

WAVE POWER

BIOMASS CONVERSION 


\section{IMPLEMENTING AGREEMENT FOR A PROGRAM TO DEVELOP AND TEST SOLAR HEATING AND COOLING SYSTEMS}

SIGNED: $\quad$ DECEMBER 1976.

PARTICIPANTS: AUSTRIA, BELGIUM, CANADA, DENMARK, EEC, FRG, GREECE, ITALY, JAPAN, NETHERLANDS, NEW ZEALAND, SPAIN, SWEDEN, SWITZERLAND, THE U.K., U.S.

OBJECTIVE: COOPERATIVE RED ON SOLAR HEATING AND COOLING SYSTEMS AND RELATED METEOROLOGICAL DATA TOPICS.

SCOPE: SPECIFIC TASKS ARE OUTLINED IN FIVE ANNEXES TO THE AGREEMENT:

- ANNEX I - INVESTIGATION OF PERFORMANCE OF SOLAR HEATING AND COOLING SYSTEMS,

- ANNEX II - COORDINATION OF RED ON HEATING AND COOLING COMPONENTS,

- ANNEX III - PERFORMANCE TESTING OF SOLAR COLLECTORS,

- ANNEX IV - DEVELOPMENT OF INSULATION HANDBOOK AND INSTRUMENTATION PACKAGE,

- ANNEX V - USE OF EXISTING METEOROLOGICAL INFORMATION FOR SOLAR ENERGY APPLICATIONS. 


\title{
IMPLEMENTING AGREEMENT FOR A PROGRAM OF RESEARCH AND DEVELOPMENT ON WIND ENERGY CONVERSION SYSTEMS
}

\author{
SIGNED: $\quad$ OCTOBER 6, 1977.
}

PARTICIPANTS: AUSTRIA, CANADA, DENMARK, GERMANY, IRELAND, NETHERLANDS, NEW ZEALAND, SWEDEN, U.S., JAPAN (JOINED APRIL 1978).

OBJECTIVE: PROMOTE COOPERATIVE RD\&D AND INFORMATION EXCHANGE REGARDING WIND ENERGY CONVERSION SYSTEMS.

R\&D EFFORTS AND INFORMATION EXCHANGE ARE ORGANIZED INTO FOUR AREAS, OUTLINED BY TASKS AND SUBTASKS IN SEPARATE ANNEXES. EACH ANNEX IS SIGNED AS A SEPARATE AGREEMENT.

- ANNEX I - ENVIRONMENTAL AND METEOROLOGICAL ASPECTS OF WIND ENERGY CONVERSION SYSTEMS. SIGNED BY ALL PARTIES; LEAD: SWEDEN.

- ANNEX II - EVALUATION OF MODELS FOR WIND ENERGY SITING SIGNED BY CANADA, SWEDEN, U.S., JAPAN; LEAD: U.S.

- ANNEX III - INTEGRATION OF WIND POWER INTO NATIONAL ELECTRICITY SUPPLY SYSTEM. SIGNED BY FRG, NETHERLANDS, SWEDEN, U.S., JAPAN; LEAD: FRG.

- ANNEX IV - INVESTIGATION OF ROTOR STRESSING AND SMOOTHNESS OF OPERATION OF LARGE-SCALE WIND ENERGY CONVERSION SYSTEMS. SIGNED BY DENMARK, FRG, NETHERLANDS, SWEDEN, U.S., JAPAN; LEAD: FRG. 


\section{IMPLEMENTING AGREEMENT ON LARGE SCALE WIND ENERGY CONVERSION SYSTEMS}

SIGNED: $\quad$ OCTOBER 6, 1977.

PARTICIPANTS: U.S., DENMARK, FRG, SWEDEN.

OBJECTIVE: FURTHER DEVELOPMENT OF LARGE SCALE WIND ENERGY SYSTEMS.

SCOPE: PARTIES WILL UNDERTAKE NATIONAL PROJECTS ON DESIGN, CONSTRUCTION, OR OPERATION OF AT LEAST 1 LS-WEC WITH A RATED POWER OF 1 MWe OR MORE. TECHNICAL INFORMATION AND TEST RESULT DATA WILL BE EXCHANGED. INFORMATION WILL BE EXCHANGED ON NATIONAL PROGRAMS, PROGRAM PLANNING, AND RËD.

COSTS: NO TRANSFER OF FUNDS. 


\section{IMPLEMENTING AGREEMENT ON THE ESTABLISHMENT OF A PROJECT ON SMALL SOLAR POWER SYSTEMS}

SIGNED: $\quad$ OCTOBER 6, 1977.

PARTICIPANTS: AUSTRIA, BELGIUM, FRG, GREECE, ITALY, SPAIN, SWEDEN, SWITZERLAND, U.K., U.S.

OBJECTIVE: DESIGN, CONSTRUCT, TEST, OPERATE, AND COMPARATIVELY EVALUATE TWO DISSIMILAR TYPES OF SOLAR POWER PLANTS, EACH OF SIMILAR ELECTRICAL OUTPUT $(500 \mathrm{kWe})$, ADJACENT TO EACH OTHER ON A SITE TO BE DETERMINED IN THE PROVINCE OF ALMERIA, SPAIN.

SCOPE: COOPERATIVE PLANNING, BUDGETING, CONSTRUCTION, AND OPERATION.

COSTS: $\quad$ TOTAL COST: DESIGN PHASE - \$1 MILLION; U.S. SHARE: $\$ 220,000$. 


\section{IMPLEMENTING AGREEMENT FOR A PROGRAM OF RESEARCH, DEVELOPMENT AND DEMONSTRATION OF FORESTRY ENERGY}

SIGNED: $\quad$ APRIL 13, 1978.

PARTICIPANTS: BELGIUM, CANADA, IRELAND, SWEDEN, U.S.

LEAD: SWEDEN.

OBJECTIVE: COOPERATE IN RD\&D AND EXCHANGE INFORMATION ON FORESTRY ENERGY ISHORT-ROTATION FORESTRY BIOMASS AND FORESTRY RESIDUE TO PRODUCE FUELS, PETROCHEMICAL SUBSTITUTES, AND OTHER ENERGY INTENSIVE PRODUCTS).

SCOPE: INFORMATION EXCHANGE AND PROPOSALS FOR JOINT RD\&D PROJECTS ON SYSTEM FEASIBILITY STUDIES, GROWTH AND PRODUCTION, HARVESTING/ONSITE PROCESSINGITRANSPORTATION, AND CONVERSION.

COSTS: $\quad$ TOTAL: $\$ 50,000$ (U.S. $\$ 10,000$ ). 


\section{IEA IMPLEMENTING AGREEMENT FOR A PROGRAM OF RESEARCH AND DEVELOPMENT ON WAVE POWER}

SIGNED: . $\quad$ APRIL 13, 1978.

PARTICIPANTS: CANADA, JAPAN, GREAT BRITAIN, U.S.

LEAD: JAPAN.

OBJECTIVE: INITIATE COOPERATIVE RD\&D AND INFORMATION EXCHANGE ON WAVE POWER

SCOPE: IMPROVE WAVE POWER ELECTRICAL GENERATION BY DESIGNING AND TESTING WAVE-POWER-PUMPED AIR-STORAGE USING COMPRESSED AIR TURBINES INSTALLED ON JAPAN'S “KAIMEI" WAVE-BREAKING BUOY.

COSTS: TOTAL: $\$ 538,000$ (U.S. $\$ 160,000$ ). 


\section{IMPLEMENTING AGREEMENT FOR THE ESTABLISHMENT OF THE BIOMASS CONVERSION TECHNICAL INFORMATION SERVICE}

SIGNED: $\quad$ MAY 24, 1978.

PARTICIPANTS: U.S., SWEDEN, IRELAND.

OBJECTIVE: COLLECT SCIENTIFIC AND TECHNICAL DATA RELATED TO RD\&D IN BIOMASS CONVERSION AND PROVIDE INFORMATION, REFERRAL SERVICES, AND LITERATURE SEARCHES.

SCOPE:

AREAS COVERED INCLUDE:

- BIOMASS PRODUCTION,

- AGRICULTURE AND FORESTRY WASTE AVAILABILITY,

- HARVESTING AND COLLECTION OF BIOMASS,

- ONSITE PROCESSING,

- TRANSPORTATION,

- CONVERSION TECHNIQUES,

- MARINE BIOMASS,

- ALgae PRODUCTION,

- ENVIRONMENTAL PROBLEMS, AND

- SYSTEMS ANALYSIS. 


\section{Bilaterals}

DC79 01221 
1) MEMORANDUM OF UNDERSTANDING BETWEEN THE UNITED STATES ENERGY RESEARCH AND DEVELOPMENT ADMINISTRATION AND THE FRENCH NATIONAL CENTER FOR SCIENTIFIC RESEARCH FOR COOPERATION IN JOINT RESEARCH ON SOLAR THERMAL CONVERSION SYSTEMS SUMMARY

2) MEMORANDUM OF UNDERSTANDING BETWEEN THE UNITED STATES ENERGY RESEARCH AND DEVELOPMENT ADMINISTRATION AND THE FRENCH NATIONAL CENTER FOR SCIENTIFIC RESEARCH FOR COOPERATION ON CERTAIN SAFETY ASPECTS OF SOLAR POWER TOWERS SUMMARY

SIGNED: MAY 1976 AND SEPTEMBER 1977.

PARTICIPANTS: U.S., FRANCE.

OBJECTIVE: SOLAR THERMAL:

- SHARE INFORMATION ON THE PERFORMANCE OF A U.S. DESIGNED AND FABRICATED CAVITY BOILER TESTED JOINTLY AT THE FRENCH SOLAR FURNACE AT ODEILLO.

SOLAR POWER TOWERS:

- ASSESS THE RISKS ASSOCIATED WITH HELIOSTAT FIELDS AND SOLAR TOWERS. 
PROJEĊt AGREEMENT BETWEEN THE SAUDI

ARABIAN NATIONAL CENTER FOR SCIENCE AND

TECHNOLOGY AND THE SAUDI ARABIAN MINISTRY

OF FINANCE AND NATIONAL ECONOMY, JOINTLY, AND THE UNITED STATES DEPARTMENT OF ENERGY AND THE UNITED STATES DEPARTMENT OF TREASURY, JOINTLY, FOR COOPERATION IN THE FIELD OF SOLAR ENERGY - SUMMARY

SIGNED: $\quad$ OCTOBER 30, 1977.

PARTICIPANTS: U.S., SAUDI ARABIA

OBJECTIVE: COOPERATION IN SOLAR TECHNOLOGY DEVELOPMENT AND FACILITATION OF SOLAR TECHNOLOGY TRANSFER.

SCOPE: $\quad$ ALL TYPES OF SOLAR SYSTEMS AND TECHNOLOGIES ARE INCLUDED:

- Centralized,

- DISPERSED,

- SOLAR THERMAL,

- PHOTOVOLTAICS,

- BIOMASS CONVERSION,

- WIND, AND

- OCEAN. 


\section{TREATY OF FRIENDSHIP AND COOPERATION BETWEEN SPAIN AND THE U.S.}

SIGNED: $\quad$ SEPTEMBER 1976 (SOLAR ACTIVITIES ARE ONE COMPONENT OF THE BROADER TREATY).

PARTICIPANTS: U.S., SPAIN.

OBJECTIVE: TEST A VARIETY OF SOLAR TECHNOLOGIES IN SPAIN IN THE CONTEXT OF THE U.S.-SPAIN TREATY OF FRIENDSHIP AND COOPERATION

SCOPE: $\quad$ SOLAR THERMAL CENTRAL RECEIVER SYSTEM, WIND AND METEOROLOGY TECHNOLOGIES, HEATING AND COOLING, AND PHOTOVOLTAICS. 


\section{AGREEMENT BETWEEN THE UNITED STATES OF AMERICA AND THE UNION OF SOVIET SOCIALIST REPUBLICS ON COOPERATION IN THE FIELD OF ENERGY}

SIGNED: $\quad$ JUNE 28, 1974.

PARTICIPANTS: U.S., U.S.S.R.

OBJECTIVE: COOPERATION IN SOLAR TECHNOLOGY DEVELOPMENT AND FACILITATION OF SOLAR TECHNOLOGY TRANSFER.

SCOPE: DEVELOPMENT OF DIFFERENT NONCONVENTIONAL FUEL SOURCES INCLUDING:

- SOLAR THERMAL, AND

- PHOTOVOLTAICS. 


\section{POSSIBLE FUTURE COOPERATION}

DISCUSSIONS ARE BEING HELD WITH THE FOLLOWING COUNTRIES:

AUSTRALIA BRAZIL ISRAEL ITALY

JAPAN KOREA

MEXICO 
Report of the Domestic Policy Review International Panel

Presented by Jack Vanderryn DOE/IA

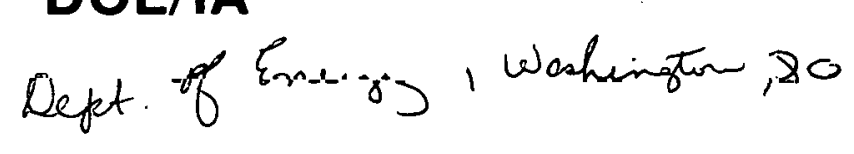




\title{
Domestic Policy Review
}

\author{
International Panel
}

\section{Summary}




\section{DPR Organization}

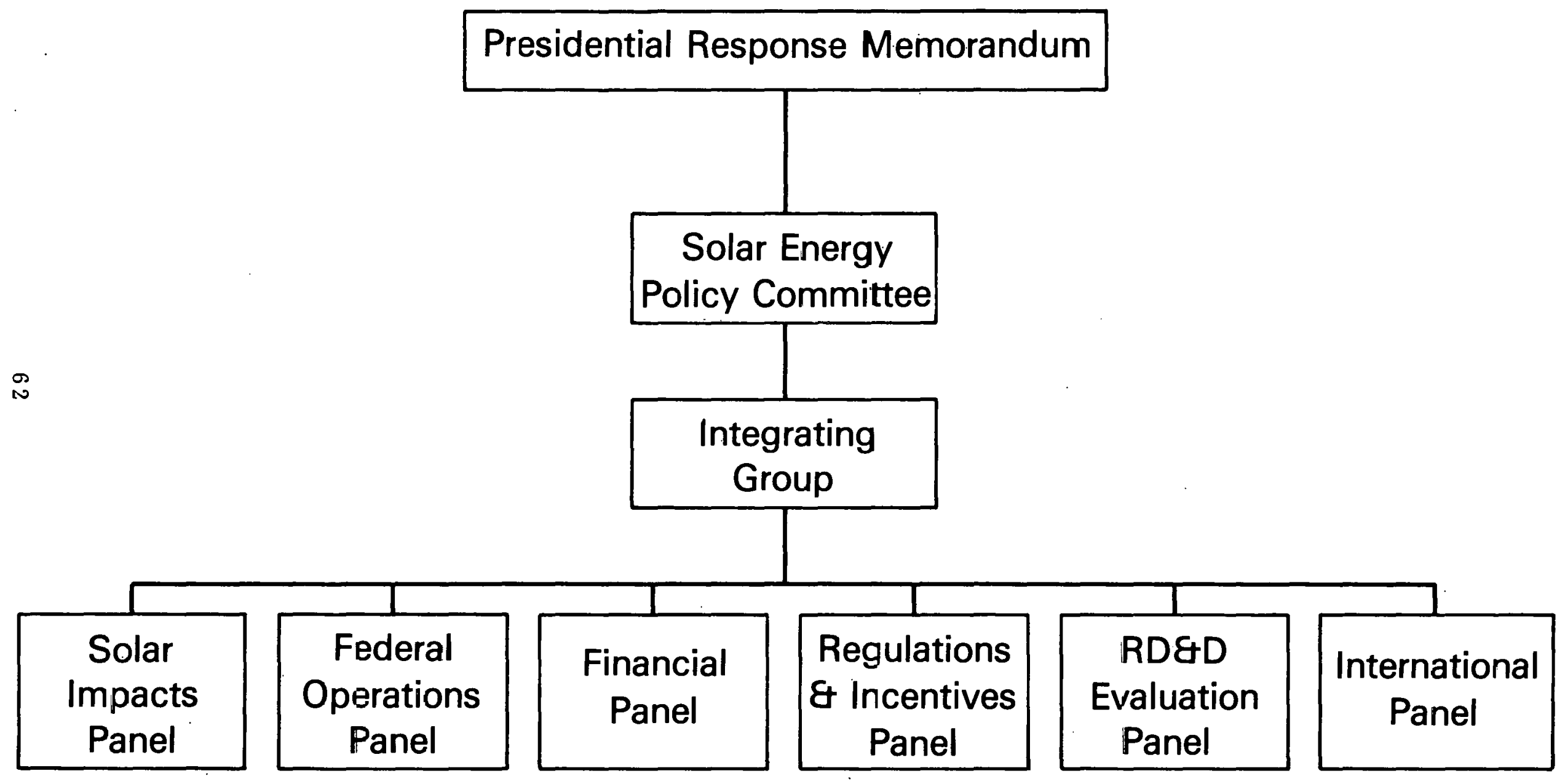

GS $7901226 / 3-13$ 


\section{Task of the International Panel}

Develop Policy Options for and Evaluations of:

(1) International Market Potential for U.S.

(2) Poțential Financial Support from International and Regional Lending Instututions for LDC Solar Development

(3) Benefits of Existing and Potential Bilateral and Multilateral Solar R\&D Projects

(4) Extent to Which U.S. Solar Expansion Abroad May Benefit U.S. Balance of Trade and Stimulate Domestic Market

(5) Foreign Policy Implications

(6) Barriers to Market Entry for Foreign Firms and Products into the U.S. 


\section{Stated Foreign Policy Goals}

- Ease Pressure on World Fossil Fuel Demands

- Cooperate with Industrialized Nations in Meeting Global Energy Challenge

- Help Developing Countries to Attain Greater Energy and Economic Self-Sufficiency

- Improve U.S. Trade and Balance-of-Payments

- Thereby Reduce Risk of Nuclear Proliferation \& Reduce Intl. Tensions 


\title{
Proposed DPR Initiatives
}

\author{
Options Group I - Commercialization \\ - Market Identification and Development
}

Options Group II - Technical Cooperation

- Development and Demonstration Projects

Options Group III - Cooperation with Developing Countries

- Financial and Technical Assistance 


\section{I - Commercialization}

A. Increasing Solar Awareness and Understanding in the U.S. and Abroad

(1) Education of U.S. Industry and State and Local Governments

- U.S.G. Information Services

- U.S.G. Overseas Market Awareness Program

- Foreign Products Information Collection and Dissemination 


\title{
Commercialization (Cont.)
}

\author{
A. (2) Education of Foreign Customers \\ - Trade Fairs, Trade Centers, Meetings \\ - Solar Demonstrations \\ - Training Foreign Solar Specialists
}




\section{Commercialization (Cont.)}

B. Encourage U.S. Industry Participation in

Developing International Solar Markets

(1) Contracts and Grants

(2) Industrial Base Development

(3) Increased Use of Export/Financing

Assistance for U.S. Industry 


\section{Initiative Two: Technical Cooperation}

Expand RD\&D with Both Industrialized and Developing Countries

- Share Cost of Research

- Exchange Information and Experience

\section{Requirements}

No New Legislative

Authority Required
FY 80-85

$\$ 380 \mathrm{M}$ Increased Level

\$200 M Maximum 


\section{Initiative Three: Developing Countries}

- Enhanced U.S. R\&D Effort for Specific Areas of World

- Analysis of Developing Countries Special Energy Needs, Resources, and Uses

- Support Training and Expansion of Local Technical Capabilities

- Testing and Adapting Solar in Developing Countries

- Demonstration Suitable Solar Technologies

- Information Exchange

\section{Requirements}

No New Legislative

Authority Required
FY 80-85 $\$ 380 \mathrm{M}$ Increased Level $\$ 600 \mathrm{M}$ Maximum 


\section{II - Technical Cooperation}

- Bilateral; Multi-Level Cooperation with Developed Countries

- Major Projects

o Industry Participation

- Ştandards

- R\&D Programs with Lesser Developed Countries

- Upper-Tier Cooperation

- Oil Exporters Cooperation

- Regional Centers

- IEA/LDC Cooperation. 


\section{III - Cooperative Programs with Developing Countries}

- Analysis of Energy Needs and Resources in Selected Lesser Developed Countries (LDC's)

- Support for Expanded LDC Indigenous Technical Capability

- Field Testing and Applied Research of Solar Energy Technologies in Some LDC's

- Demonstration and Evaluation of Proven and Applicable Solar Energy Technologies

olnformation Dissemination and Awareness Efforts on the Possible Applications of Solar/Renewable Energy Resources 


\section{Cooperative Agreements as Benefits to U.S. Industry}

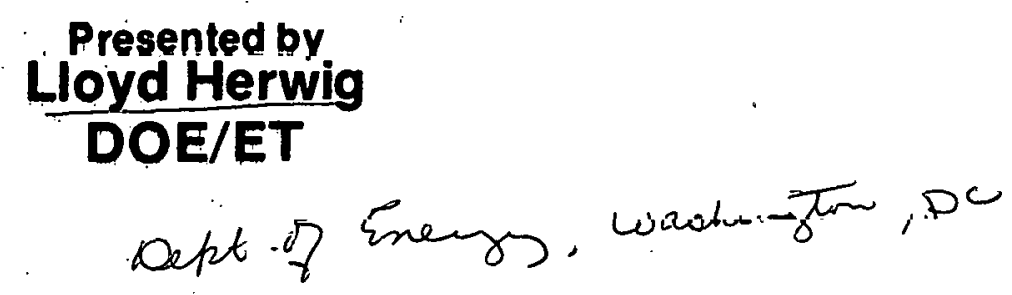




\section{DOE INTERNATIONAL ACTIVITIES}

- International Affairs (IA)

- General liaison responsibility

- Developing country program

- Energy Technology (ET)

- RD\&D support (solar electric \& biomass)

- Conservation and Solar Applications (CS)

- RD\&D support (heating \& cooling)

- Commercialization 


\section{TYPES OF INTERNATIONAL COOPERATIVE ACTIVITIES}

- Information and visit exchanges

- "Published" reports, national program activities, and facility visits

- Cooperative projects based on common activities

- Individual projects funded by each country separately

- Project information and experience exchanged

- Joint-funded and managed cooperative projects 


\section{INTERNATIONAL COOPERATION IN RD\&D QUESTIONS}

- Technology giveaway versus gain

- Potential loss of U.S. jobs and exports

- RD\&D cooperation versus risk of competition

- Involvement of local industry in intemational commercialization

- High technology versus low technology 


\section{SUMMARY OF INTERNATIONAL SOLAR COOPERATIVE RD\&D PROJECTS}

- R\&D projects with France, Canada and Denmark

- IEA small solar thermal power system project

- Other IEA projects

- U.S./Saudi Arabian solar agreement

- Cooperative projects with Italy, Israel and Brazil currently under negotiation 


\section{IEA SMA_L SOLAR HERMAL POWER SYSTEMS}

- U.S. program funds about $25 \%$ of total project

- About \$7 million for phase II construction (\$3O million project)

- German (DFVLR) lead in project integration; U.S. deputy role (Sandia)

- DOE headquarters representation on Executive Board

- Two side-by-side 500 kW system under discussion

- Distributed recelver-parabolic trough-Acurex, et al. design

- Central receiver-sodlum cooled-Interatom, MM, et al. design

- Almeria, Spain, site-operational 1981

- Competitive solicitation for multinational industrial consortia 


\section{U.S./SAUDI ARABIA SOLAR AGREEMENT}

Initial Projects in 1979

- Village solar power project-large photovoltaic system

- Socio-economic and energy requirements study for the solar village (Al-Uyaynah)

- Solar data collection project for Saudi Arabia

- Saudi Arabian cooling R\&D project

- U.S. cooling demonstration project

January 1979 


\section{U.S./SAUDI ARABIA SOLAR AGREEMENT}

Village Solar Power Project in Saudi Arabia

- Site has been selected (Al-Uyaynah; 2000 people)

- $350 \mathrm{kWe}$ photovoltaic system to supplement diesel system

- RFP to be issued for integration contractor by early CA 1979

- First-phase design and construction of $50 \mathrm{kWe}$ system by mid-1980; second-phase construction of an additional $300 \mathrm{kWe}$ by early 1981

January 1979 


\section{U.S./SPAIN SOLAR PROJECT ACTIVITIES}

- Funds from U.S./Spain Treaty of Friendship (1976)

- About $\$ 1$ million annually for 5 years

- SERI management overview

- Five projects being developed

- ST central receiver-design \& engineering assistance-SLL

- HC commercialization planning-survey \& demonstrationFIRL

- WC engineering development-design \& engineering assistance-LeRC

- PV R\&D-double sided silicon cells-Case Western U.

- BM urban waste utilization-methane gas productionU. of Illinois

- Project development fitted to treaty conditions 


\section{U.S./ITALY SOLAR PROJECT ACTIVITIES}

- U.S. program funds to be matched by ltaly

- About \$1 million annually (U.S. funds) for several years

- SERI management overview

- Four projects being discussed

- PV remote applications-several 2-5 $\mathrm{kW}_{\mathrm{p}}-\mathrm{SAL}$

- PV remote applications-2O-3O kW system-SAL

- ST remote applications-5O kW system-SAL

- ST central receiver-study for Italian electric grid-SLL

- Probable joint U.S./Italy competitive solicitation 


\section{U.S./ISRAEL SOLAR PROJECT ACTIVITIES}

- U.S. program funds matched by Israel

- About \$1 million annually (U.S. funds) for several years

- SERI management overview

- Four project areas being discussed

- HC advanced cooling systems-design \& testing

- HC solar ponds-industrial process heat

- PV RD\&D-advanced concepts \& materials

- BM agricultural waste-conversion to clean fuels

- Probable joint U.S./Israel competitive solicitation 


\section{INDUSTRIAL BENEFITS OF RD\&D COOPERATION}

- Company experience in working on overseas projects

- Company exposure in overseas markets

- Possible formulation of advantageous joint ventures

- Increased familiarity with foreign technology and business practices

- Better adaptation of systems to overseas conditions

- Additional sales of equipment and services 


\section{OVERSEAS EXPORT/MANUFACTURING PHASES}

1. Start exporting - Introduce new product into foreign market

2. a. Foreign demand rises sufficiently for U.S. firm to begin manufacturing product in foreign country (overseas subsidiary)

b. Exporter licenses toreigner to produce product overseas

c. Technology process sold outright to foreign manufacturer

3. a. Competition begins within foreign country.-Indigenous manufacturers compete with foreign subsidiary for domestic market.

b. Joint venture formed as foreigner buys part of subsidiary

4. Foreign producers begin exporing to U.S. and elsewhere 


\section{INDUSTRIAL APPROACHES TO INTERNATIONAL SOLAR PROJECTS Broad Options for Government Involvement}

- Private U.S. companies go on their own

- Government assistance through indirect activities

- Intergovernmental technical and procurement assistance

- Direct government involvement in planning and managing of projects under cooperative agreements 


\section{INDUSTRIAL APPROACHES TO OVERSEAS COMMERCIAL ACTIVITIES}

- U.S. company sales of turnkey systems or projects

- U.S. system integrator with in-country representative

- In-country system integrator with U.S. industrial subcontractors

- In-country representative for U.S. company products

- In-country manufacturing under license 


\section{RISKS IN OVERSEAS COMMERCIALIZATION ACTIVITIES}

- Inexperience in market assessment and development

- Changing local circumstances and ground rules

- Time and transportation difficulties

- Competition with government-industry combines

- Unforeseen business, customs or language difficulties

- Lack of local infrastructures and standards 


\section{PHOTOVOLTAICS INTERNATIONAL DEVELOPMENTS}

- Market analyses show remote photovoltaic systems to be cost effective for many applications at 4 to $\$ 5$ per peak watt of installed system, e.g., village and rural electric power for water pumping, lighting and irrigation

- DOE program goals call for installed costs of 4 to $\$ 5$ per peak watt by 1982

- First operational photovoltaic village power system (3.5 kWe) dedicated on December 16, 1978 at Schuchuli, Arizona

- RFP in early 1979 for Saudi village solar power project 


\section{FEDERAL PHOTOVOLTAICS PROGRAM (PL 95-590) International Aspects}

- Calls for delivery of an international plan to assure that American industry gets a substantial share of the overseas photovoltaic market

- Requires delivery of a plan by November 1979

- Involves delivery of a detailed plan outlining new approaches and options to be considered during a following analytical study

- Seeks suggestions of ideas and options from all interested sources

- Total $\$ 1.5$ billion over 10 years; $\$ 125$ million for $\mathrm{FY} 79 ; 10 \%$ set aside for small business

January 1979 


\section{INTERNATIONAL GUIDEBOOK OF SOLAR TECHNOLOGIES}

- Brief oveniews of solar technologies, U.S. program goals, technology status and budgets

- Outline of U.S. program and management organizations

- Descriptions of U.S. information resources

- Listings of major projects and facilities, professional associations, international agreements, educational opportunities, projected solar impacts, and selected bibliography 


\section{CATALOG OF AVAILABLE SOLAR TECHNOLOGIES}

- Meets criteria of availability and system experience

- Provides broad information base for generic systems

System descriptions, general applications, system experience, needs for system engineering development and adaptation, present and future power and equipment costs, projected implementation schedules

Potential in-country industrial involvement

- Provides basic decision data for program planners

- To be updated periodically as part of commercialization effort 


\section{CRITERIA FOR CATALOG LISTING}

- Category 1: Commercially-available systems with a substantial warranty on system life and performance and/or components

- Category 2: Industrially-available systems where multiple user-oriented demonstrations or experiments are in operation

- Category 3: Industrially-available systems where at least one user-oriented demonstration or experiment is in operation

- Category 4: At least one experimental system in operation

January 1979 


\section{SERI CONTACTS FOR INTERNATIONAL AGREEMENTS}

- International Program Branch

Solar Energy Research Institute (SERI)

1536 Cole Boulevard

Golden, Colorado $804 \mathrm{OI}$

(3O3) 231-1218

- U.S./Saudi Arabian Program Office

Solar Energy Research Institute (SERI)

1536 Cole Boulevard

Golden, Colorado $8 \mathrm{O} 4 \mathrm{OI}$

(3O3) 231-1257 
THIS PAGE INTENTIONALLY LEFT BLANK 


\section{COMMERCIALZATION ACTIVTTES: NTERNATIONAL SOLAR COMMERCIALIZATION $=\quad$ WORKING GROÜP (ISCWG)}

William L. Corcoran, Chairman Department of Energy, Office of Conservation and Solar Applications Washingtion, $1 \mathrm{C}$

In the last session I described commercialization as bridging the gap between research and development and a commercially viable product or system. Expanding on that, commercialization of solar energy involves joint actions by the Federal Government and industry that:

- accelerate the process of industrial product development and marketing,

- increase consumer use of solar energy worldwide, and

- increase the export of U.S. solar products and services.

I previously described the objectives and strategy for international solar commercialization. Let us examine some of the activities of the ISCWG. First are foreign market surveys and application studies - already mentioned - which would be done in cooperation with DOC. We want to pinpoint the areas of greatest export potential and pass this information on to the U.S. solar industry. The second activity is information dissemination. This conference is a first step in improving communications. Another step is to inform foreign organizations and consumers about U.S. solar products and services. This information process is done in a number of ways, including trade missions, shows, and seminars as conducted by DOC and by solar demonstration projects in potentially good market areas.

Standardization will aid in worldwide consumer acceptance of solar products worldwide and metrification will help U.S. industry sell components and subsystems in competition with other developed countries. Cooperative agreements, also mentioned earlier, help everyone by worldwide use of solar energy. Export aids such as the guarantees and loans of the Export-Import Bank will be of great help to the U.S. industry. Export incentives in the form of tax legislation is another possibility that needs consideration. In addition to export of products and services, U.S. industry can export manufacturing processes through licensing arrangements and train foreign workers in manufacturing processes both in the United States and abroad.

The benefits of international solar commercialization are many: as U.S. production of solar products is accelerated, unit costs are reduced, balance of payments is helped, the dependence on fossil fuels and nuclear energy is reduced, developing countries are helped in meeting their energy needs, and there is a favorable impact on multinational cooperation in research, development, demonstration, and acceptance. To obtain these benefits, the DOE plan of action included the establishment of a working group, the ISCWG, with responsibility for formulation of a commercialization program plan through the following actions: conducting research and collating current and proposed solar energy commercialization activities; coordinating with interested and involved federal agencies and the U.S. solar industry; identifying the best foreign markets and assessing the U.S. share of these markets; preparing a plan of recommended solar activities; and finally, implementing the plan.

One of the ISCWG objectives is information acquisition and analysis through all available 
sources including visits to selected countries to assess solar activities and plans and potential for near-term applications, U.S. export, international cooperation, and solar demonstration. In addition, we want to develop a communications infrastructure involving: U.S. foreign missions and posts; foreign governments, organizations, companies and universities; and international organizations such as the UN, IEA, NATO, and World Bank. Finally, this information will be incorporated into DOE plans and made available to other federal agencies to incorporate into their plans.

An initial information acquisition trip included eight European, eight African, and four Middle East countries. The types of contacts made on each trip apply equally to all countries visited. These contacts and general observations from these fact-finding missions are summarized in the vugraphs.

Most countries are energy importers with higher costs than the United States and need energy assessments; all are interested in developing solar energy. The needs and desires of the developing countries are fresh water, agricultural and fish processing, and electricity for remote areas; appropriate systems; the capability to manufacture solar energy products; and technology transfer, training, and demonstration plants. Industrialized countries want cooperation and joint ventures. U.S. competition is primarily France, Germany, and Japan. For all countries we see: photovoltaics as the most promising U.S. export; solar hot water systems as readily available (some are subsidized, and hence not promising for export); interest in the result of the U.S. solar energy program; and information dissemination as a key to cooperation, joint-ventures, and marketing.

We made a first cut at rating marketing opportunities using a scale of 5 as highest and 1 as lowest. Greece, Senegal and Saudi Arabia were ranked the highest; Italy, Israel, Niger, Ivory Coast, Egypt, and Kuwait were next; France, Spain, Switzerland, Cameroon, and Nigeria were near the middle of the scale; West Germany, United Kingdom, Kenya, and Iraq were of low potential; and Belgium was ranked the lowest of those surveyed.

Prior to and during the trips, Congress considered and passed authorization for the Secretary of State to demonstrate solar and renewable energy technologies in foreign service buildings. During our visits we found that most missions were interested. There were some problems, however, such as accessibility and visibility by local people, security, available space, potential construction delays, and difficulties in building permit renewal. The authorization became law (P.L. 96-426) on October 7, 1978. This program is a good first step in getting our mission and posts involved in promoting worldwide use of solar energy.

With respect to early commercial potential of solar technologies there was greatest interest in photovoltaics for decentralized and relatively low power applications from watts to a few kilowatts. Of general interest was solar cooling and refrigeration and acquisition of advanced U.S. technology. We found many potential near-term agricultural and process heat applications. Biomass is timely for R\&D cooperation, especially using USDA. Wind conversion appeared to have relatively little appeal although it serves well for electric generation and water pumping in remote and windy areas. Solar hot water and space heating has broad applications and falls within many in- 
country capabilities. Desalination and distillation have a broad application for islands and seacoast communities. Ocean thermal was of interest only in Ivory Coast which has favorable conditions for an on-shore plant.

The many benefits of the ISCWG activities are indicated on the vugraphs. We contributed substantially to the President's domestic policy review of solar energy which Jack Vanderryn will explain. We have demonstrated initiative and interest in helping U.S. solar industry towards international solar commercialization. We are bringing a systems approach to planning, developing a commercialization infrastructure, and establishing an information resource on international solar organizations, plans, activities, and contacts.

Our specific recommendations to accelerate worldwide utilization of solar energy, to expedite the U.S. solar commercialization program, and to develop applicable hardware for international acceptance are indicated on the vugraphs.

In conclusion, the ISCWG has provided the mechanism to get actions started on achieving our objectives of promoting worldwide use of solar energy in general and U.S. solar products and services in particular. We expect to do a lot more and solicit your comments for more effective methods of achieving these objectives. 


\section{Solar Commercialization}

Actions That -

- Accelerate process of industrial solar development and marketing

- Increase consumer use of U.S. solar products and services

- Increase export of U.S. solar products and services 


\section{International Solar Commercialization}

- Foreign market surveys and applications studies

- Information dissemination

- To U.S. business on export opportunities/federal help

- To foreign organizations/consumers on U.S. solar products and services

- Trade missions, shows, seminars

- Solar demonstration projects in potential market areas

- Standardization

- Cooperative agreements stimulating world-wide use of solar energy

- Export incentives

- Product manufacturing process licencing/sales

- Foreign worker training 


\section{Benefits}

- Accelerate U.S. production of solar products

- Reduces unit costs for domestic and foreign use

- Helps U.S. balance of payments

- Reduces world-wide dependency on fossil fuels and nuclear energy

- Helps the energy needs of developing countries

- Impact on R\&D, D\&D and D\&A cooperation 


\section{Action Plan}

- Establish ISCWG with responsibility for formulating commercialization program plan

- Research and collate current and proposed international solar energy commercialization activities

- Coordinate with interested and involved federal agencies and solar industry

- Identify foreign market potential and conduct U.S. market share assessment

- Prepare plan of recommended solar commercialization activities

- Implement plan 


\section{ISCWG Objectives}

Visit selected countries to assess:

- Solar activities and plans

- Near term applications potential

- U.S. export potential

- International cooperation potential

- Solar demonstration potential for U.S. mission buildings

Develop communications infrastructure involving:

- U.S. foreign missions and posts

- Foreign government organizations, companies and universities, etc.

- International organizations

Incorporate information into:

- DOE Planning

- Other U.S. government planning 


\section{Information Acquisition - Phase I}

Trip

Europe

Africa

Middle East

Saudi Arabia, Iran, Egypt, Iraq*,

Kuwait* , and Israel

Workshops Genoa, Cairo, and Seminars Hamburg

* Experts contacted at Cairo and Data from posts
Contacts

- U.S. embassies, consulates and trade centers

- Foreign Government organizations

- Universities

- Foreign companies

- International and regional organizations - IEA, EEC, UNECE, NATO, COMPLES, UNEP

- U.S. companies 


\section{Observations}

Most Countries

- Energy importers; costs higher than U.S.

- Need energy assessments

- Want to develop, use solar energy

Developing Countries

- Need solar energy most for fresh water, agriculture and fishing, electricity for remote areas

- Must have systems appropriate to local needs

- Want own solar energy manufacturing capability; may buy plants

- Want technology transfer, training, demonstration projects 


\section{Industrialized Countries}

- Want cooperation, joint ventures

- France, Germany promoting solar energy in developing countries

\section{All Countries}

- Photovoltaics most promising U.S. export

- Solar hot water systems readily available; some subsidized

- Want information on U.S. solar energy program

- Information dissemination key to cooperation, jointventures, marketing 


\section{U.S. International Cooperation and Commercialization Opportunities}

Greece Highly favorable factor; geographically strategic

Senegal Great needs, plans, activity and interest

Saudi Arabia High interest; available capital

홍

Italy

Israel

Cooperative attitude; dispersed solar activities

Niger

Cooperative attitude; competitor

High government interest; active and good potential

Ivory Coast Favorable attitude; highly active, interested

Egypt

Great needs; high government interest

Kuwait

Capital available; high government interest 


\section{U.S. International Cooperation and Commercialization Opportunities}

(Continued)

France Cooperative attitude; key competitor

Spain Cheap oil; discourages U.S. imports

Switzerland Limited resource; hardware competitor

Cameroon Limited potential; high interest

$\stackrel{\circ}{\sim}$

Nigeria

Energy rich; limited interest

West

Germany Strong export competitor; limited solar resource

U.K. Limited solar resource; selected solar interests

Kenya Limited potential; selected interest only

Iraq Limited interest

Belgium Low interest; minimal activity 


\section{Solar Energy Demonstrations at U.S. Missions}

Most missions interested

Areas requiring further assessment

- Accessibility/visibility to local people

ம

- Building security

- Available roof space

- Potential construction delays

- Impacts on building permit renewal 


\section{Early Commercialization Potential}

\section{Great Interest}

- Photovoltaics

Decentralized power generation applications

General Interest

- Solar cooling/ refrigeration

Selected Interest

- Agricultural and Many potential near-term applications industrial process heat

- Biomass

- Wind

- Solar hot water and space heating

Acquisition of advanced U.S. technology

- Desalinization/ distillation

Timely for R\&D cooperation

Electric generation/water pumping in rural-remote areas

U.S. specialized technology of some interest although local know-how exists

Broad potential including island and sea coast communities

Little Interest

- Ocean thermal

Limited interest 


\section{Benefits}

- Contributes substantially to DPR International panel and other commercialization activities

- Demonstrates U.S. Government initiative to assist U.S. solar industry in international commercialization

- Brings systems approach to U.S. international solar

$\Xi$ planning

- Develops U.S. solar commercialization infrastructure

- Establishing information resource on international solar organizations, plans, activities, and contacts 


\section{Recommendations}

Accelerate world-wide use of solar energy by:

- Technical cooperation in solar energy $R \& D$

- Commercialization, including near-term demonstrations and global market assessments

- Financial and technical assistance to developing countries

Expedite the U.S. domestic solar commercialization program through:

- U.S. industry involvement

- Increased markets

Develop U.S. hardware and systems for international applications

- Adapt and modify existing equipment

- Develop new systems and components for specific needs

- Simple and lower cost systems

- Adopt metrication

- Emphasize compatibility of technology/applications with local resource assessments 
THIS PAGE INTENTIONALLY LEFT BLANK 


\title{
THE INTERNATIONAL ENERGY DEVELOPMENT PROGRAM
}

\author{
A. Nelson Tardiff \\ LDC Programs \\ Department-of Energy, Office of International Affairs

$$
\text { Wachingtow, QC }
$$

The International Energy Development Program (IEDP) constitutes a new U.S. bilateral initiative in relationships with developing countries that was initiated by the President in September 1977. The program aims at developing an awareness of appropriate nonnuclear energy alternatives and supports other U.S. policies concerned with U.S. export expansion, world energy supply, and economic development assistance. A pilot phase of the program has been conducted and demonstrates that it is broadly capable of supporting these policy objectives. In its present form, the program accomplishes this through collaborative energy assessments with selected developing countries. Two such assessments were performed in Egypt and Peru during the pilot phase.

I will briefly describe the activities that were undertaken in the pilot program, and the results, and outline some of the more general conclusions that can be inferred from the first year's activities.

The IEDP provides an incentive for developing countries to plan for energy expansion in directions other than nuclear: it is supportive of expanded U.S. export trade in both commodities (such as solar energy and conventional power plant equipment) and services (such as consulting and engineering); it stimulates the development of renewable resources worldwide by identifying unexploited energy potential and promoting energy conservation and efficiency; and finally it brings to bear expert U.S. know-how and judgement on crucial issues and contributes directly to the efficacy of the development process.

The primary goal of the pilot effort was to demonstrate that the United States can collaborate with developing countries, using a systematic approach and appropriate analytical methods, to arrive at an understanding of a country's long-term energy supply and demand balances.

The expectation is that this process can lead to:

- the development of energy strategies consistent with countries' indigenous resources and development objectives, as well as U.S. foreign policy goals;

- the establishment of an analytical framework for energy planning; and

- the development of a sound basis for focusing U.S. and other national and multilateral assistance, cooperation, and financing in the energy field as well as in related areas.

The IEDP has been managed by the DOE under the policy guidance of an Interagency Group that is chaired by DOS. DOS was responsible for country selection under the pilot program and determined that there were two essential criteria for selection: receptivity of the country to using a cooperative, systematic, and rational approach in choosing an energy strategy; and availability of genuine energy alternatives on which to base such strategies. Egypt and Peru were selected for energy assessments because they offered the best combination of factors at the time. 
The energy assessments were conducted by two teams of U.S. experts under the direction of DOE in a collaborative effort with Egyptian and Peruvian officials and technical experts. A variety of experts (in energy technologies and resources, development economics, and analytical methods) comprised the teams. Cooperation was exceptional and collaboration was close at all levels (ministerial, executive, and technical counterpart) in the interactions between the U.S. teams and the Egyptians and Peruvians.

The countries' economic development and energy development plans were reviewed, economic and energy resource bases were analyzed, energy supply and demand options for future target years were developed, and overall strategies that maximize reliance on the available indigenous resources were defined. Information was obtained through published sources and personal interviews. An analytical framework developed by the Brookhaven National Laboratory (BNL) was used as a tool for energy accounting; a facilities costing model developed by Bechtel Corporation was used to estimate the cost implications of the energy facilities required in each strategy.

Reports that present the results of the energy assessment and describe the practicable alternative strategies to meet future energy requirements have been compiled and presented to the authorities in the participating countries for possible implementation. The effort resulted in the most comprehensive overall energy assessments of Egypt and Peru undertaken to date.

I would like to briefly summarize the actual findings of each of the assessments, touching in turn on energy demand, the available resources, the strategies that were defined, and the capability of each government to implement them. Further details on these points are provided in the prepared text of my presentation; I will only exccrpt them here.

The Egypt assessment arrived at the following general conclusions:

- Egypt faces a formidable challenge in meeting its energy needs due to scarce indigenous resources, rapid population growth, and inadequate government planning with respect to both energy and economic development.

- Although indigenous energy resources are limited, there are nevertheless some contributions by nonnuclear energy resources which can serve to satisfy a large part of Egypt's future needs.

- Through the year 2000 , Egypt's demand for commercial energy must be supplied primarily by conventional fuels using existing technologies. However, Egypt's current institutional and technical capabilities are not adequate to carry out the major expansion of energy supply that will be required.

The assessment considered several energy production and resources options to meet future energy demand. These resource options include hydro, geothermal, solar, natural gas, coal, uil, and nuclear. Un the basis of these energy resource options, seven alternative strategies were formulated, each calling for a different mix of both production and utilization of these resources. They include greater use of natural gas, improved efficiency in the use of energy, increased use of solar and other renewable technologies, and medium and minimal use of nuclear power.

Prior to this cooperative assessment, Egyptian Government plans called for nuclear power to meet about $80 \%$ of the annual electric energy demand by the year 2000. As a result of this joint evaluation, Egyptian planners have become more aware of the major financial, technical, management, and manpower resources that will be required to undertake such a program, and they are now re-examining their plans. 
The following overall observations emerged from the Peru assessment:

- Peru has abundant natural energy resources for long-term development, but it faces severe short-term problems of economic and financial instability;

- Peru has an abundance of renewable resources-namely, hydropower, biomass, geother mal,and solar energy; and

- Peru has made no formal commitment to a nuclear energy program, and it appears that nuclear power would be a costly alternative energy source, in view of Peru's vast hydro-electric potential.

Peru is confronted by acute short-term" problems: they face a growing external debt ( $\$ 8$ billion in 1978); spiraling inflation (41.3\% in 1977); falling productivity; and collapsing world prices for its principal exports, copper and fishmeal. If current austerity programs are successful in overcoming these difficulties, "commercial" energy consumption could triple between now and the year 2000 (to some 500,000 barrels of oil per day equivalent), with oil accounting for more that three-fourths of the future demand.

As in the case of Egypt, the assessment considered several energy production and resource options to meet future energy demand. These resource options include oil, coal, gas, hydroelectricity, biomass, geothermal, and solar. On the basis of these energy resource options six alternative energy strategies were formulated, each calling for a different mix of these various resources.

By implementing a combination of all of these strategies, oil consumption in the year 2000 could be reduced by $28 \%$. Were this to occur, all internal oil demand could be met with indigenous production with a surplus for export of several thousand barrels per day.

We can draw a number of conclusions about the specific activities that we conducted jointly with Egypt and Peru, and we can draw more general inferences about the applicability of this type of activity. I will first discuss Egypt and Per $u$, and then touch on the more general aspects.

By encouraging the examination of a broad range of energy development alternatives, the assessments have provided Egyptian and Peruvian officials with a better information base for their energy planning decisions. These governments now have a clearer understanding of the extensive commitment of economic and human resources that will be required should they choose to develop and sustain a major energy program based on advanced energy technologies. As a direct consequence of the assessment, Egyptian planners are seriously questioning their previous goal of 12,000 MWe of installed nuclear power capacity by the year 2000 .

Through the year 2000, it appears that Peru will have adequate energy supplies from nonnuclear sources, particularly hydropower, to meet projected demand. As a result, it would be difficult for Peru to justify a commitment to nuclear power on resource or economic grounds for at least the next two decades and probably beyond. Peru's current nuclear program is a long range effort that focuses primarily on nuclear physics research and medical, industrial, and agricultural radioisotope applications.

Each assessment report includes a description of priority actions to be undertaken by the host country, either to implement a particular strategy or to acquire the additional 
information necessary to support a final decision on the most appropriate energy development strategy. The assessments also provide guidance for future selection of energy-related projects by the Agency for International Development (AID), the World Bank, and other donors.

The U.S. Embassy and AID Mission in Lima echoed the views of the Embassy and Mission in Cairo about the usefulness of the collaborative effort to date. Both also consider it essential that subsequent work be undertaken to assure that these countries have the capability to continue the assessment process by themselves and to establish investment priorities.

Both Egypt and Peru have expressed their appreciation for the assessment activities, have indicated that they believe the work to be very useful, and have requested that cooperation continue. The World Bank has endorsed the approach and the European Economic Community is considering undertaking a similar type of activity under the Lomé Agreement, currently being renegotiated.

The pilot phase of the program indicates it is broadly capable of supporting the foreign policy objectives of the United States concerned with nuclear nonproliferation, trade expansion, world energy supply, and development assistance:

- By identifying attractive energy alternatives, the program provides an incentive for developing countries to plan for energy expansion that considers nuclear energy in a more realistic and appropriate manner.

- In the long run, the program will support expanded U.S. export trade in both commodities and services. Trade-in equipment for solar energy, such as photovoltaic cells and panels, as well as other types of capital equipment required to exploit renewable energy resources, is likely to be stimulated. Consulting and engineering services related to the energy field will also be affected favorably.

- Through stimulating the development of renewable resurces, identifying unexploited conventional energy potential, and promoting energy conservation and efficiency, the program has promise of augmenting world energy supply. It should be recognized, however, that these factors may be much more significant on a country-by-country basis than for the world as a whole.

- The program contributes directly to the efficacy of the development process. It brings expert U.S. know-how and judgement to bear on issues which are crucial in economic and social development. It enhances the probability that future energy needs will be met, and thus contributes directly to achieving development goals. Through increasing the rigor of the energy planning process, it influences the discipline of related planning astivities.

In addition to supporting the previously stated foreign policy objectives of the United States, the IEDP appears to achieve additional side benefits such as: an expanded information base for U.S. foreign policy formulation; greater efficiency in the future application of energy assistance programs; and enhanced leverage on other assistance programs. 


\title{
EXPORT POTENTIAL FOR PHOTOVOLTAIC SYSTEMS
}

\author{
R.S. Campbell \\ Battelle-Pacific Northwest Laboratories \\ Richland, Washington
}

These remarks preview the results of a congress-mandated study prepared for the DOE Office of the Assistant Secretary for Conservation and Solar Applications under the supervision of Ms. Elaine Smith. The report will be available to the public in April 1979 under DOE Publications No. DOE/CS-0057.

The export market for photovoltaic power systems offers a challenging and historically significant opportunity for American technology. The study briefly described here assesses the size of the opportunity and the challenges and problems associated with attempting to capitalize upon it. The report's six major sections, not all of which can be discussed here, are as follows:

- Characteristics of technology and market

- Market size estimation

Demographic-need

Qualitative

Quantitative

- Market share estimation

- Competitive assessment

- Competition dynamics

- Policy considerations

To start with the issue of market size, truly new technologies usually face the problem at their inception that it is notoriously difficult to estimate their market potential. This leads to the following caveat: "numbers don't count if someone does something to change them." I am reminded that the basic patents for xeroxgraphy were unsuccessfully offered to IBM, NCR, Kodak and others, all of whom declined on the grounds that xeroxgraphy could never compete with wet copying and the li carbon paper.

We have attempted to measure market potential by several methods. The first we have termed a "demographic need-assessment" which focuses on village power systems. NASA, which has an excellent high attitude vantage point, claims that there are 3 million villages on this planet not connected to power grids. Of these villages, approximately 1 million are in what $\mathrm{I}$. $\mathrm{H}$. Usmaini of the UN has called the "SOLAR BELT" located $30^{\circ} \mathrm{N}$ to $30^{\circ} \mathrm{S}$ of the equator. Using Usmaini's averages, the typical village needs about $9 \mathrm{~kW}$ of peak panel capacity to meet the minimal energy requirements for 500 people. (This is about the same level of capacity used by two mythical average Americans if residential and commercial use are included.) Multiplying through the estimated level of need is on the order of 9,000 MW of capacity.

Unfortunately, need is one thing and ability and willingness to pay is another. If we are conservative and assume that such villages can afford to satisfy only $10 \%$ of their energy needs, we are still left with a truly substantial market of 900 MW. To keep pace with 
population growth, the Third World countries will need about $4 \mathrm{MW}$ more in 1979 just to maintain present per capita energy levels at the level of village power alone (four times present U.S. production capacity).

However, before we get carried away, we need to know if Third World nations and foreign countries in general are even interested. This brings us to the second market size estimation approach: the qualitative assessment. There we have drawn upon the work of the ISCWG. This is the most extensive onsite assessment of market potential for solar technology yet conducted. Those reports of interviews with decisionmakers, administrators, and experts should be read in their entirety; however, suffice it to say that these surveys of significant actors in Europe, Africa, and the Middle East report that there is keen interest in photovoltaic technology. The LDCs recognize that the petroleum path is closing. The most likely alternative is the path including photovoltaics.

Our third approach to assessing market potential is a quantitative assessment which we used to develop a conservative base case predicated on the assumption of purely evolutionary growth. This assessment was performed by Tom Jaras and Orin Merrill of Science Applications Inc., and uses the following assumptions:

- no improvements in technology beyond the normal production learning implicit in the DOE PV price goals,

- no change in government PV or export incentives, and

- business as usual behavior on the part of U.S. industry.

This assessment is conservative in that it focuses primarily on growth projections for known present day applications. It does not take into account potential applications that do not have a track record and that may emerge because of projected or unanticipated price reductions. This assessment projects that the market in the next seven years (1986) or so will be in range of 15-130 $\mathrm{MW}$ per year depending on a variety of assumptions. Again, these are intended to be conservative for both the U.S. and foreign market figures.

Given a range of values for the size of the market, what may we expect the U.S. share to be? Again, we have been conservative and have drawn upon three different economic approaches largely based on our historical experience as an exporter. Assuming no change in government export policy or incentives, the best model estimates give the United States from 10-30\% of the mature market. If a concerted effort is made in both the private and government sectors, this potential might go as high as $60 \%$, the approximate U.S. share in semiconductors, airframes, turbine engines, and radioactive materials.

Again, let me repeat the caveat that there is nothing immutable about these sort of numbers. Photovoltaics is a new, barely emerging industry and nothing is locked so tightly in place at the moment as to preclude a larger export market or our share of it. Our assessment of competitive strengths indicates that the United States presently leads in cell technology. However, we have no monopoly on science or technology, hence we should remember that in a technology race you can never stop running. We expect that the technology race will be crucial in second and third generation cells.

We find that European firms are ahead in building their marketing infrastructure and in building integrated application systems for the Third World. It is significant to note that 
of the 30 or so PV demonstration projects of the EEC nations all but one are in lessdeveloped countries. Read that as an indication of where the market is.

The Japanese are beginning their first foreign sales. At first blush it may appear that they are off to a slow start. However, in most of the markets they now dominate, they did in fact enter late. However, by offering high quality, reasonably priced products sold by truely formidable marketing skills, they have of ten been successful to the exclusion of their foreign competitors.

We should not be surprised by either the European or Japanese marketing strengths. These nations have been in the export business for a long time, largely out of necessity. They have developed some important effective export incentives which we might do well to investigate closely.

In summary, photovoltaics represents a very large potential market which has attracted some strong initial contenders. How well we succeed in capturing a significant share of that market depends on how aggressively we go after it in terms of price, technology, and marketing. 
THIS PAGE INTENTIONALLY LEFT BLANK 
Vincent J. Riley

\section{ENERGY-RELATED ACTIVITIES OF} THE WORLD BANK

World Bank

Washingtom $\partial c$

Although a number of speakers have referred to the World Bank and identified us with some of the activities already discussed, I think it would be appropriate for me to begin by describing the World Bank. The World Bank is an international organization, a specialized agency of the UN. It is owned by 133 member governments, and it finances projects in developing countries in Asia and Latin America, in agriculture and inf rastructure, power generation and distribution, and industry, as well as in a number of fields where one can identify potential use of solar energy such as education, rural development, telecommunications, forestry, and so on. The World Bank's task is to finance economically justifiable projects which will contribute to the development of borrowing countries and raise the living standards for their people.

Let me turn now to the subject more immediately at hand. In the rural areas of developing countries, there are 750 million of the world's poorest people. We just had a very interesting presentation of statistics on the number of villages and the potential amount of power needed in those rural areas. Improvement of the condition of these 750 million absolute poor, as the president of the Bank has referred to them, the meeting of their basic human needs, is the urgent political and economic task that is facing the developing countries. Critical to this process is the need to overcome their acute energy shortage. Most of the rural poor are not now reached by electrical power grids and are not likely to be reached by such grids any time soon, any time in this century. Oil and gas are increasingly costly, especially if imported, and exhaustible. The continued use of fuelwood and other traditional fuels is possible only at considerable cost to the environment and the resources needed for food production. For these and other reasons the need for small, localized, decentralized power sources is increasing significantly, and the demand for power from renewable resources is a potentially significant part of this whole.

Let me try to share with you some of our thinking and experience in the World Bank on these issues. I will pass over some of the processes that have already been dealt with-the use of biomass, fuel wood, small hydropower, wind energy systems, and the use of direct solar power for heating water and drying crops and fish. Many of these processes are well-established in the world and, as already been noted by previous speakers, the equipment for it is widely available on a commercial basis. Where appropriate, our borrowers use the proceeds of bank loans to acquire such equipment, primarily from suppliers in the industrialized countries.

I want to focus attention on the development and application of other techniques that are, or have the potential of becoming, economic in the near or medium term. These include solar pumps, solar electric power, and other devices capable of playing a role in the developing world-particularly devices with potential as a decentralized source of energy on farms and in small communities in rural areas. Serious financial, institutional, and social constraints need to be overcome if these energy alternatives are to play a role in the development process. To overcome these constraints, the World Bank is encouraging its developing member countries to focus on the problems, as well as undertaking some economic and applied technological research itself. Part of this is done through World Bank loans, and let me give you some examples.

An industrial development project in Israel has provided funds for applied research intn 
the use of nonconvective solar ponds as a means to collect and store energy. A commercial prototype heating and cooling system is being built in a hotel near the Deac Sea. This project also includes U.S. funded $\$ 1.5$ million for the development of solarpowered engines which are being designed to require little maintenance so they can replace small diesel engines in various village applications. In Bolivia, a bank-sponsored rural development project in the high semiarid plains of the Altiplano will provide funds to help a local institution adapt and develop local solar energy devices for heating, pumping, food drying, and greenhouse agriculture. There are other examples but I think it is probably appropriate to skip over them at this point.

Outside of its lending operations, the bank has recently undertaken on behalf of the UN Development Programme a $\$ 1.2$ million project to adapt existing solar technologies for use in small-scale pumping applications. Over the next two years this project is intended to demonstrate the technical feasibility of these devices; to investigate their economic aspects under actual field conditions. To accomplish this, two separate technologies will be tested: solar thermal and photovoltaic. The tests will be done side by side with a series of photovoltaic pump applications and at least one solar thermal application in each of four countries. The goal is to see which will prove most suitable for use by small developing country farmers. The tests are planned in Mali, in India, in the Philippines, and in the Sudan. The goal, ultimately, is to identify a technology or a set of technologies suitable for a small-scale operation (200 - 300 watts peak power in the photovoltaic process and up to one to three kilowatts in the case of the solar thermal pumps). We are looking for processes that would be available at low enough cost to make the process suitable for use on small farms. We believe that the market potential of a successful small-scale pump is enormous and I think the figures that were given by the last speaker certainly tend to bear this out. By the end of this century it could amount to many millions of units and then we probably would only be reaching $5 \%$ of the market, according to some of the calculations made by our staff.

A project manager has recently been selected for this project. He will come onboard the end of this month, and a short list of technical consultants is about to be invited to submit formal proposals to carry out this project. Later this year, sometime in the late spring, we will be soliciting formal proposals from equipment firms who are interested in providing either components or the complete pumping units. If anyone is interested in this, I would be happy to provide more information on it.

In addition, a developing country buyer or user wants a reliable, trouble-free device. This will be one of the characteristics that we will be looking for in the pumping program that we are carrying out for the UN Development Programme.

There is a desire, ideally, for trouble-free service, but with a guarantee of backup and replacement where necessary. The buyer will expect the package to bc opcrahle and maintainable by locally available people who will of ten be unschooled and certainly will know virtually nothing about solar energy. Developing country purchasers will, of course, expect that the solar power units have been packaged to withstand tropical conditions-circumstances of extreme temperature and humidity, problems of seepage of fine dust, of fogging and of fungal and algal overgrowth, etc.-problems with which I am sure many of you are already familiar.

Small-scale solar devices continue to be relatively capital-intensive projects, costing several times as much as, for example, the gasoline generator. For this reason, the cost and availability of capital will be a major concern for potential developing country customers, and they will no doubt wish to know where the credits can be obtained on 
conditions sufficiently favorable to make solar units attractive compared to other more conventional sources. Provision of that capital is, of course, the business of the World Bank, as well as the business of some of the other people on this panel today. We are prepared to consider financing solar energy along with other sources of power and to accept it where it appears technically sound and appropriate and makes good economic sense. We try to share our experience and to communicate such wisdom as we may acquire along the way, recognizing, however, that the borrower's decision and judgment will ultimately determine the extent to which solar energy will be used in meeting development problems. 


$$
\begin{aligned}
& 13 \\
& 13
\end{aligned}
$$

THIS PAGE INTENTIONALLY LEFT BLANK 


\section{SPECIFIC PROGRAMS OF THE EX/IM BANK}

Francis-E. Wilson, Jr., Loan Officer*

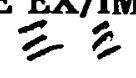

Export-Import Bank of the United States

washniztion te

Jack Bierman gave you an overview of what we do at Ex/Im Bank this morning. I thought it might be useful to spend a few minutes to discuss some specifics of our programs that might be of interest to you. First, I would like to draw a distinetion between two broad segments of Ex/Im Bank. The first is the direct credit program. This is generally reserved for very large projects or expensive products. A threshold would be about $\$ 5$ million. Normally, when we lend money we have a great deal of privity in this situation with the foreign buyer. There tends to be a fair amount of red tape: it involves a loan agreement and a lot of lawyers. The supplier credit programs, probably more applicable to your own circumstances, are easier to use. I am going to concentrate on two of those today. The supplier credit concept is almost the opposite of our direct credit program. It encompasses a large percentage of what we do at Ex/Im Bank. The suppliers are the ones that we normally deal with. We rarely get involved with the foreign buyers. The supplier is responsible for putting together the transaction with the help of the commercial bank they normally work with. But it is the supplier we deal with. The risks we normally cover through our bank guarantees or insurance policies are generally both political and commercial. The political risks are usually things such as revolution, eivil insurrection, and cancellation of an export license, for example. The commercial risks covered are insolvency and protracted default. We do not cover things such as a cancellation of a contract. So the risks we cover are specific. As you can see, we attempt to put you in a position to extend reasonable financing terms to a customer abroad which can vary with the size of the transaction and the type of product you are selling.

Now I would like to discuss the FCIA insurance program. FCIA is an unusual institution. It was begun about 1961 with the cooperation of over 50 large insurance companies. They established an association which issues all our insurance policies, collects all the premiums and does a substantial percentage of all the underwriting necessary to evaluate the risks. They operate as our agent through a reinsurance agreement. This agreement requires that we take all the political risks and some of the commercial risks associated with FCIA's policies. For that consideration we split the premiums with FCIA. This relationship has been a good one. FCIA has prospered since 1961, and now does a substantial percentage of all our supplier credit business. FCIA is our only means of assisting exporters who normally sell on a short-term basis (from terms such as cash, up to 180 days open account). This covers a large percentage of exports that go forward from the United States. In many cases, it is because of the type of product being sold; agricultural commodities or industrial commodities, products that have a short-shelf life, a high turnover, or a low unit value. The short-term insurance policy that FCIA issues to both commercial banks and exporters requires that the exporter insure all eligible sales abroad throughout the course of a year. In return for that consideration, they are provided a small discretionary authority so that FCIA only has to examine the larger accounts for credit worthiness. Furthermore, the exporter is charged a relatively low premium for this insurance. The percentage of protection the exporter can expect with

*Frank Wilson is a senior loan officer at the Ex/Im Bank. He has been with the Bank for six years and was formerly with the corporate banking division Paine Webber, Jackson, and Curtis. 
the short-term insurance policy is usually $95 \%$ political cover, and $90 \%$ commercial cover. Besides the relatively low unit value products that are usually insured under a short-term policy, large capital equipment could also be covered if a longer repayment term is not necessary.

The medium-term insurance that FCIA issues, however, is issued exclusively for more expensive items and on a case-by-case basis. That is, if you have a potential sale abroad, you can approach FCIA for a policy to cover just that sale. The medium-term insurance differs from the short-term insurance in that we require a $15 \%$ cash payment by the buyer to be made at, or about, the time shipment is made. The balance, usually repayable on at least a semi-annual basis over a period of 6 months to 5 years depending on the size of a transaction, is evidenced by a series of notes. It is the repayment of these notes that the insurance policy is assuring. Usually the percent cover under medium-term insurance with a few exceptions is $90 \%$ political and $90 \%$ commercial. The cost for the medium-term insurance will vary with the type of security offered and the repayment term. For example, a note guaranteed by a bank or a government obligation would be cheaper than the nongovernment or unsecured transaction. Generally, depending on how long the repayment term is likely to be, the cost will vary from $1 / 2$ of 1 percent to 5 percent. It is payable after shipment and it is a one-time-only fee. That cost can be passed on to the foreign buyer (it usually is), and can be a part of the total package being financed and insured.

In addition to FCIA's short and medium-term programs, Ex/Im Bank offers a program that somewhat duplicates the medium-term FCIA Insurance. We refer to it as our medium-term Bank Guarantee Program which has proved to be attractive to exporters such as yourselves. We deal actively with about 300 commercial banks throughout the United States in this program. Perhaps one of them could be your local bank. With our guarantee, these banks are in a position to offer you the financing for your sale to your customer abroad. Again, the products are normally capital or quasi-capital goods. The degree of participation on the part of the exporter is the same as it was for the FCIA medium-term insurance policy: you can expect to have $10 \%$ share of the political risks, and a $10 \%$ share of the commercial risks throughout the repayment of the obligations. Again, there is a $15 \%$ cash payment required. Most of these 300 commercial banks, because of their satisfactory experience with Ex/Im Bank, have the discretion to approve the credit worthiness of your customer and provide on-the-spot financing without consulting Ex/Im Bank. In other words, the commercial bank itself can make the decision as to whether or not to commit Ex/Im Bank's guarantee. I am talking about typical transactions valued up to several hundred thousand dollars each. The advantage for you is that is reduces the time it takes to get the financing package finalized. I do not have to tell you that time can sometimes mean a sale. We encourage you exporters to work closely with your commercial banks when you think you have a sale abroad, or better, before you go abroad to start marketing your products.

Under this program the commercial bank participates in the transaction. If the bank commits the transaction we ask them to pick up $15 \%$ of the commercial risks af ter your $10 \%$ has been factored out. However, the Bank Guarantee Program is priced very similarly to the FCIA medium-term Insurance Program, so you have a choice to make as an exporter as to whether you use a bank guarantee, with the cooperation of your bank, or whether you use a medium-term insurance policy. Both the medium-term Insurance Program and the Bank Guarantee Program can be altered to accommodate repetitive sales. If you have a dealer or something akin to a dealer abroad and want to sell to them on a repetitive basis, this can be arranged so that you only need get the buyer's credit approved once a year. If the transaction is especially large, the bank will submit it to 
Ex/Im Bank for our consideration to determine whether we agree that it is a creditworthy transaction.

In addition to our support for the sale of your products abroad, we also can assist the sale of services such as design feasibility or engineering studies. Generally these services are provided and financed on a short-term basis. You expect to get paid pretty much as you perform the service, but in some instances you might be asked to provide a longer term for repayment. Depending on the size of the transaction, it might be as long as five years. Under those circumstances, we stand ready through FCIA or your commercial bank to offer support to you so that you can provide the service, accept the repayment obligation, and in turn, sell that obligation to convert it into a cash sale for yourself.

We cannot emphasize strongly enough the necessity for you to think in terms of financing your exports. General Motors would sell few automobiles if they required cash for each sale, and there was no banking community in the United States ready to provide the financing. That is exactly the type of situation many of you are going to be confronted with when you attempt to sell your products abroad. There is no viable commercial banking network in many countries able to provide your customer with the financing he may need. Through our support you can bring your local commercial bank's services with you when you make your sales abroad.

I would like to mention two very simple examples that reflect how we might become involved. An exporter suddenly finds himself in a position to sell his products abroad, initially on a letter of credit, or fairly secure terms. He is not really asked to provide any financing. After visiting with his customers, the exporter realizes that he could expand his sales considerably if he were able to offer more liberal terms of 30,60 , or 90 days for sales to his present buyers and attract additional customers. Maybe some of the customers would be willing to inventory his products for resale if he would provide them with some time before they would have to start paying him back. Under either of these circumstances, he might do well to investigate with FCIA the advantages of a short-term policy. The policy can be issued to cover most sales that he is likely to have abroad for a whole year. They can probably negotiate a level of discretionary authority that would be adequate for the exporter to approve the credit for his small sales at least. If the sales to each customer are larger, perhaps the exporter would consider accepting a first loss deductible. As you would expect of your automobile insurance policy, you will get a lower rate, and the discretionary authority will be higher. This is not an unusual example of how a small businessman gets involved with FCIA using a short-term insurance policy.

An example of the use of a Bank Guarantee might be an exporter trying to negotiate a sale of a piece of capital equipment in a country like Mexico. Perhaps it is a $\$ 200,000$ sale and before he goes to finalize his sale, he would do well to talk to his commercial bank to find out exactly what type of repayment term he could expect to offer the buyer in Mexico and under what circumstances. If his banker uses our Bank Guarantee Program he would advise the necessity of a $15 \%$ cash payment. The exporter would be required to accept a $10 \%$ participation in the risks of nonpayment throughout the life of the repayment obligation. The rate of interest the exporter would quote the buyer in Mexico would be something that his commercial bank would find acceptable. If necessary the exporter could quote a lower rate of interest, but if he does, he is going to have to compensate the commercial bank to make it attractive for the bank to purchase the obligation. Under these conditions the transaction would work like this: a $\$ 200,000$ sale, a $\$ 30,000$ cash payment, the exporter would accept a $\$ 17,000$ participation on a declining basis throughout the life of the notes. The commercial bank would accept a $15 \%$ share of the commercial credit risks in that transaction if it made the credit decision. If the bank 
instead preferred to send the transaction to Ex/Im Bank for us to make a judgment, the commercial bank's participation would be dropped to $5 \%$ of the commercial risks.

We stand ready to try and make you as competitive as we possibly can, but it is up to you to make the sales. We are not out there making the sales for you. But we sincerely want to work with you. For quite some time we have been running orientations on a routine basis for people like yourselves or your commercial banker. The telephone number of our Public Affairs Office is: (202) 566-8297. If you call us, we will be happy to schedule you for one of our orientations.

In closing, I would like to refute an old story. It seems the two oldest lies in mankind are: "The check is in the mail," and "I'm from the government; I'm here to help you." We at Ex/Im Bank are trying to disspell the last part of that. We can't do anything about the check in the mail, though. 


\section{INTERNATIONAL ACTIVITIES OF THE SMALL BUSINESS ADMINISTRATION}

Fred S. Fleischman, Regional Loan Specialist

Small Business Administration, Atlanta Regional Office

$G A$

To start, I would like to read a teletype we received late yesterday afternoon which might enlighten some who are interested in the Small Business Administration's (SBA) part in solar energy.

"Public loan 95-315 approved on July 14, 1978 authorizes the SBA to
establish a small business energy loan program to be implemented
within six months. Effective with publication of the final regulations
and the register of January 5 , 1979 , the SBA field officers can accept
loan applications under this program using regular SBA application
Form 4 and related forms. Note all energy type loans will be made
under this program of the Small Business Act. Loan officers should
presently utilize the final regulations in processing and making the
lending decision. The standard operating procedure is currently being
prepared and will be distributed as soon as possible. There have been
set aside for the second quarter of FY79, specifically for this program,
$\$ 5$ million in direct loan funds and $\$ 1 / 2$ million in loan guarantee
authority. (That's for each particular type loan.) These forms will be
held in the central office and distributed on a case-by-case basis as
were the other program as the handicapped assistance loan program we
have to operate from out of our central office. Any questions on this
program are to be directed to Arthur Armstrong, Director of Office of
Financing or any member of his staff."

If you decide that you want to get particular information on this program, you can contact your nearest SBA office and they will assist you.

There are 96 SBA offices throughout the United States (that includes the district offices as well as branch offices): SBA covers just about every area that can possibly be served. It is very easy to arrange an interview pertaining to solar energy, export loans, or other business loans in these offices. There are eligible and ineligible types of businesses. Most retail, wholesale, service-type activities, and small manufacturing plants are eligible. There are, however, a few exceptional businesses that are not eligible which include speculative type businesses. These include any that could be contrary to local state laws.

We do have size standards set up for SBA. For instance in the retailing-type businesses we have a $\$ 2-\$ 71 / 2$ million size standard ceiling depending on the type of retail activity. Services can run from $\$ 2-\$ 8$ million depending on the particular activity, and wholesaling can run from $\$ 91 / 2-\$ 22$ million and still be within the small business realm. Manufacturing falls into a different classification and the small-type eligibility would depend on the number of employees-which can run up to 1500 depending on the type of manufacturer-and what products are manufactured.

The purposes of SBA loans are to help small businesses primarily to get additional machinery and equipment, to build additional facilities or a new facility to satisfy working capital needs, or other similar uses needed by small business. The maximum amount of SBA loans is normally up to $\$ 350,000$; however, under such conditions and 
qualifications, SBA can make a loan to an individual type business up to $\$ 500,000$. Most of our loans involve bank participation; that is, we guarantee a large portion of a loan-up to $90 \%$-to a small business, the bank makes a loan, we act as a guarantor. They service the loan and carry on all the normal servicing functions with the individual business.

The interest rate on SBA loans at the present time (maximum amount) is $111 / 4 \%$. On direct loans, it is $73 / 8 \%$. We do make direct loans, but we have been limited increasingly in the last few years; therefore, I would say $96 \%$ to $97 \%$ of the loans made by SBA are the bank participation guarantee-type loans with a bank involved. The maturity on our loans can run up to 20 years if construction is involved under the use of proceeds. Most of the working capital loans run from 7 to 10 years. Purchase of machinery and equipment loans run in the neighborhood of 8 to 10 years maximum. The agency tries to gear the maturity of these loans to the use of the particular loan and to the extent that it is considered reasonable by financing people.

The banks play a very large part in the SBA program: we work closely with the banks and communities throughout the country. The loan program has (as far as the SBA regular business loan program) done exceptionally well. The credit requirements for SBA loans are: (1) there is reasonable assurance that the loan can be repaid from earnings of the business; (2) there is management in the business to indicate that the business can be operated successfully; and (3) collateral is available to secure the loan so the bank and SBA will be protected. The primary interest emphasis, however, is the demonstrated ability to repay the loan. We also have other functions within SBA such as management assistance, procurement assistance, disaster assistance, etc. I think your major concern now, though, is the financial assistance that SBA plays in the economy. 
Session IV

The Industry - Industry Case Studies 


\title{
Small Business Case Study
}

\author{
Presented by \\ Gary Neuner \\ Acurex Corporation \\ prtt. Vine,$\subseteq A$
}




\title{
SMALL BUSINESS CASE STUDY
}

\author{
Acurex Corporation \\ 485 Clyde Avenue \\ Mountain View, California
}

Presented By

Gary Neuner

Manager

Photovoltaic and International Programs 


\section{INTRODUCT.ON}

- Acurex Background

- Essential Elements

- Problem Areas

- Characteristics of a Small Business

- Conclusions 


\section{ACUREX CAPABI IES}

Systems

Program Management

Analysis

Design

Construction Management

Maintenance

Hardware

Research and Development

Production 


\section{A : IRTX AC.'VI.IES}

Systems

Irrigation

Industrial Process Heat

- Hot Water

- Steam

Concentrating Photovoltaic

$\nsubseteq \quad$ Flat Array Photovoltaic

Hardware

.ow-Cost Flat Plate Thermal Collector

Thermal and Photovoltaic Line Focus Concentrator

Novel Concentrator Concepts 


\section{ACUREX INTERNATIONAL EXPERIENCE}

- International Energy Agency (IEA) Small Solar Power System Project

- Trade Shows

- International Solar Conferences

- Licenses and Joint Ventures 


\section{IEA PROJECT}

- 500 kW Solar Power Plant in Spain

- Distributed Collector System (DCS)

- Central Receiver System (CRS)

- Government-Type RFP (Request for Tender)

- Funded by 10 Countries

- Work Must be Performed by 10 Countries

- Active Government Involvement 


\section{ESSEN A IN ERNA IONA \\ B ISINESS E E.MEN S}

- Need and Committment

- Economic Parity

- Financial Ability

- Stable Government

- Demonstrated Product

- Foreign Associations

- Working Capital 


\section{PROBLEM AREAS}

- Business Relationships

- National Pride

- Communications

- Monetary Constraints

- Cost 


\section{BI S NESS RE A, ONSHIPS}

- Contractual Arrangements

- Consortia

- Joint Ventures

- Licenses

- Government Involvement 


\section{NA I JNA SR'DE}

- Europeans are Accomplished Exporters

- U.S. Has a Technology Lead

- Foreign Systems Can Cost More

- Colonial Influence 
-. Language

- Culture

- Proximity

- Limited Means of Communication 


\section{MONETARY CONSTRAINTS}

- Currency Fluctuations

- Inflation

- Foreign Government Financing

- Taxes

- Complex Import Duties and Restrictions

- Profits Generated in Foreign Countries 


\section{$\cos$ or $\left[r^{-N}\right]$ OVERSEAS BI S'NESS}

- Travel and Living Expenses

- Office and Support Services

- Length of Time to Conclude Deals

- Communications

- Product Compatibility

- Shipping 


\section{C'IARAC E.IS CS OF A SMA ' B SINESS}

- Typically Limited Exposure to International Markets/Marketing

- Limited Resources

- Management Experience 


\section{NC- I'SIONS}

International Business is:

- Giant Opportunity

- Profitable

- Expensive

- Highly Complex

- Risky

Therefore, Before Entering Market:

- Plan Carefully

- Prepare for Expense

- Get Expert Advice 
THIS PAGE INTENTIONALLY LEFT BLANK 


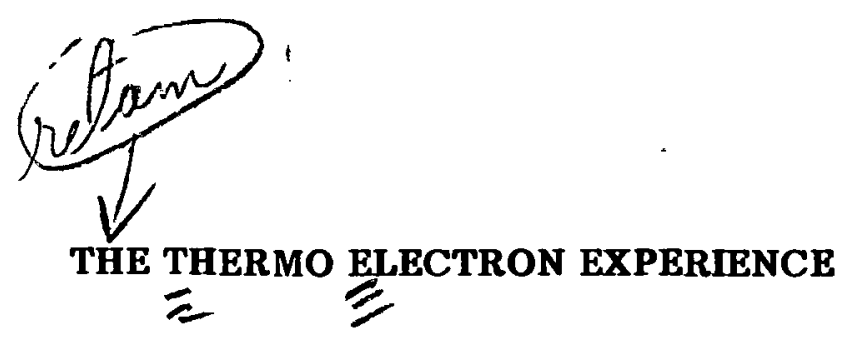

J.T. Keiser

Thermo Electron Corporation

Waltham, Massachusetts

I would like to describe Thermo Electron Corp. and our experience in overseas marketing of remote location solar systems. The company was founded in the late 1950s. The initial business of the company was to conduct government funded research in the area of thermionics, the direct conversion of heat to electricity. Over the years, the company has grown to a sales volume of over 100 million dollars per year with 1800 employees and divisions in several foreign countries.

Our largest division is the Holcroft Company, a manufacturer of industrial furnaces. We also have subsidiaries involved in heat treating, papermaking equipment, environmental and health monitors, and cogeneration power systems. These businesses are located throughout the United States and also in Canada, England, Mexico, Brazil, and Saudi Arabia.

Our group is at the Corporate Research and Development Center in Waltham, Mass., just outside Boston. The R\&D center provides new products and technologies for the company as well as conducting government and privately sponsored research. There are 300 people employed in Waltham working on projects related to solar energy, thermionics, energy conversion, power systems, appliances and instrumentation, as well as biomedical and cancer research. The common element that runs through the corporation is the development of products and technologies based on the efficient utilization of energy.

Our involvement in the overseas solar energy market began with our analysis of the solar market in general based on our perceptions of Thermo Electron's strengths and weaknesses. About three years ago, we became quite interested in solar energy as a growth area for the company. With our experience in product development and our technical expertise in thermodynamics and systems engineering, we felt that we should look carefully at entering the solar field. After evaluating Thermo Electron's positioning and recognition in the domestic market as well as our estimation of the growth areas and type of expertise needed, we decided to forego entering the domestic consumer market.

Since we were already involved in international marketing and had an established capability in power systems design, we concluded this area offered a better opportunity. We had to weigh this against the relatively high cost of doing business outside the United States, especially in developing countries, but we felt that we could establish a more significant position in the remote location solar system market than we could, for example, in domestic water heating or air conditioning. Our corporate experience in international business, our rapid growth, and our commitment to energy conservation teohnologies were important faotors in the decision.

The specific product area we chose to pursue was remote location solar systems. These units can be used to generate power, cool, light, irrigate, or perform numerous other tasks.

Our initial emphasis has been on solar thermal systems because of our well-established capability in this area and some early sales opportunities. We are equally interested in 
photovoltaic systems and the choice of system will depend on the particular application at hand. Our in-house areas of expertise cover all aspects of solar thermal systems including the design, development, and fabrication of collectors as well as all components of the thermal loop ranging from heat exchangers to turbine expanders. We do not manufacture photovoltaic cells, and in these systems, we obviously will turn to the established suppliers to meet our needs for components and subsystems. We feel that this broad technical base, coupled with our systems engineering capability, puts us in a good position to compete successfully in remote power systems ranging in size from hundreds of watts to hundreds of kilowatts.

The choice of remote location systems as our product immediately narrowed the target market. A major portion of our sales effort is directed toward the third world or developing nations. This grouping includes both underdeveloped countries and those classified as middle income which are no longer receiving extensive foreign aid grants. Geographically, this breaks down to Africa, Southeast Asia, Latin America, and the Middle East.

In our brief experience in approaching this new market, we have made several observations. For funding, we look to the international agencies such as AID, UN, and the World Bank, who are providing grants and loans to these nations. In the more developed middle income countries, we look to private, commercial, and regional sources. The Middle East offers another alternative of approaching some of the wealthier nations directly to finance their own projects.

These broad geographic areas offer many challenges and we must evaluate each country and specific site location separately. Problems range from the present political situation to the apropriateness and acceptability of the technology for a village culture. Failure to study any of these factors can result in major difficulties.

Host country involvement is an important consideration. Our sales contacts have shown that many developing countries are more interested in participating in a project than having sophisticated products and technologies placed in their country without appropriate means of maintenance and support. Given the nature of solar energy itself, many countries wish to begin their own industry and they expect us to give them a helping hand, typically, in such low technology areas as flat-plate collector production. In addition, we have become sensitive to the fact that a project is not likely to succeed unless we have the cooperation of all parties involved, especially the end users. One way to enhance this cooperation is to find a partner in the host country. This partner can either be a government agency or private entity, but we believe the effort spent establishing this contact will pay dividends as a project progresses.

It is a necessity from both the customer relations and system design standpoint to fully appreciate the circumstances in the host country. In our experience, this can only be accomplished on a first-hand basis. This type of travel expenditure is factored into all our plans to market any system.

There are a myriad of difficulties ranging from environmental considerations to the educational and cultural patterns of the users. It is quite possible to provide a product that can work in the United States but will be unsuitable for use in a remote overseas location. The avoidance of this problem is essential in an unproven area such as solar energy, where a single failure reflects on the industry as a whole. One way we try to prevent this problem is to have our engineering personnel visit the customer and include them in all discussions concerning background information on the project. A final 
requirement after planning the sales approach and designing a system is patience. Things move slowly and we find ourselves investing a great deal of time in selling and negotiating before realizing a contract.

At present, we are working on a solar irrigation project located in the west African country of Senegal. The design and installation involve all the typical problems associated with remote location systems. Funding for this program is unique because of the fact that both the U.S. and French governments are providing support. Thermo Electron is carrying out the U.S. portion and Sofretes, our French counterparts on this project, are interacting with the French government. The following is a brief description of this program to illustrate what can be expected in implementing this type of system.

Senegal is located in the Sahel region of Africa, which lies to the south of the Sahara Desert and is, at best, semi-arid. Serious droughts have plagued the area during the past 40 years. The period 1965-1974 was particularly difficult: annual rainfall totals were well below the normal amounts, which are already meager. Much of northern and eastern Senegal is included in the Sahel region. (Figure 1.)

The government of Senegal is seeking to provide tangible assistance to their people. A program is underway to implement numerous irrigation projects along the banks of the Senegal River. A reliable supply of water pumped from the river to adjacent cropland will substantially improve agricultural yields in the region, with attendant improvements in the health and living conditions of the local population. The village selected for this project is Bakel, located about 500 miles inland on the Senegal River.

Several irrigated perimeters already exist in the area and more are being prepared and planned. Diesel engines are providing the power to pump water from the Senegal River to these perimeters. Like most African countries, Senegal has no domestic oil production and is highly vulnerable to price increases of imported petroleum products. Sunshine, on the other hand, is an abundant natural resource in the Sahel. The government of Senegal, therefore, has concluded that a solar-powered water pumping system is a promising solution to the dual problems of drought and rising costs of imported fuels.

Figure 2 is an artist's concept of the Bakel Solar Irrigation Plant. The system will convert incident solar radiation to thermal energy, which will be used to drive a Rankine-cycle thermal loop. The thermal loop will produce mechanical shaft power which will in turn drive a pump that lif ts water from the Senegal River to the irrigated perimeter.

Approximately $20,000 \mathrm{ft}^{2}$ of flat-plate solar collectors will provide energy for the system. They will be located on the roofs of buildings and on open structures. Pumping will begin each day at approximately 10:00am. The thermal energy storage subsystem will permit operations to continue until approximately $8: 00 \mathrm{pm}$, depending on the time of year. The agricultural plan contemplates year round crop cultivation in the 500 acre irrigated perimeter. The system, therefore, will pump water every day of the year, solar condltions permilling.

The basic elements of the solar thermal pumping system are illustrated in Figure 3 . The solar collector loop includes the flat-plate solar collectors, a water reservoir for thermal storage, pumps, and a heat exchanger to deliver energy to the thermal loop. Water is pumped through the collectors, heated by the incident solar radiation, and delivered to the heat exchanger or the storage tank, depending on the rate at which energy is being collected. During periods of high solar radiation, excess energy is stored in the reservolr 
in the form of hot water and when solar radiation is inadequate to provide the total amount of energy needed for the thermal loop (as occurs at the end of each day), energ! stored in the reservoir is withdrawn to meet the needs of the system. The thermal lool converts heat to mechanical energy by means of an organic Rankine-cycle. In the boiler, Freon is vaporized, then expanded through a turbine to create mechanical shaft power. The Freon is condensed, and waste heat rejected to the cooling water, in this case, a flow of irrigation water from the river. The liquid Freon is then pumped to the boiler to repeat the cycle.

The turbine output shaft is coupled through appropriate gearing to the mechanical pump. Although the river level varies throughout the year, the nominal pumping head is $33 \mathrm{ft}$ and the corresponding delivery is 1.7 million gal/day. An alternator is also driven from the turbine shaft to provide electrical power for system start-up, controls, and local lighting. Under nominal conditions, shaft power output from the turbine is $35 \mathrm{~kW}$ : approximately $5 \mathrm{~kW}$ is converted to electrical power, and the remainder is used to drive the irrigation pump. The system design philosophy is one of conservatism rather than sophistication with emphasis placed on simplicity and reliability, as opposed to higher performance.

While it is obvious that design and performance are important, equally critical problems are logistics, site preparation, and installation of the system. On this project, we have a subcontract with Sinaes, a Senegalese based firm working in the solar energy field. They have provided invaluable assistance in arranging overland transport from Dakar to Bakel and in resolving interface requirements with the local civil engineering firm who will provide the buildings, collector support structures, and river facilities. Because of the relatively large size of the system, the collector will be assembled onsite from hardware shipped from the Unites States. Even broken down into basic elements, the collector components will occupy containers having a total volume of some 15,000 cubic $\mathrm{ft}$ and weighing 75 tons. Overland transport will require a caravan of fourteen trailers. Complicating the situation is the fact that roads to Bakel are poor under the best of circumstances, and totally impassable during the rainy season. The rains extend usually from June to September or October and project activities must he scherduled accordingly.

The Bakel project is a 20 -month program which began in July of 1978 and is scheduled for completion in January 1980. We are now in the process of preparing the collector hardware for shipment with the objective of arriving in Bakel before the rainy season. Assembly will take place in the fall of 1979. We will rely heavily on the support of Sinaes to oversee the installation of the system and to provide the local labor component required.

In closing, I would like to note a few points that in some respects may be unique to our particular products and markets, but in many cases are common to all companies involved in solar equipment export. To reemphasize host country involvement, it is important that time and consideration must be given to designing products appropriate for their location and intended use. The only way we can do this is to visit the country and obtain local cooperation. An industry in its infant stages, such as solar, cannot afford to sell products that turn out to be unsatisfactory to the customer. In addition, we would like to see more aggressive assistance in the marketing of U.S. solar technology overseas. Trade shows are important, but what we need is some really agressive help from embassy staffers in promoting U.S. goods. Finally, it is very difficult to compete with French and West German firms who not only have embassy assistance, but government subsidies for some projects. 
In summary, we believe there is a market for U.S. solar products abroad, and the agressive promotion by our government of U.S. solar technology as a solution to the energy problems of developing and middle income nations will aid immeasurably in the export of solar hardware. 


\section{SENEGAL}

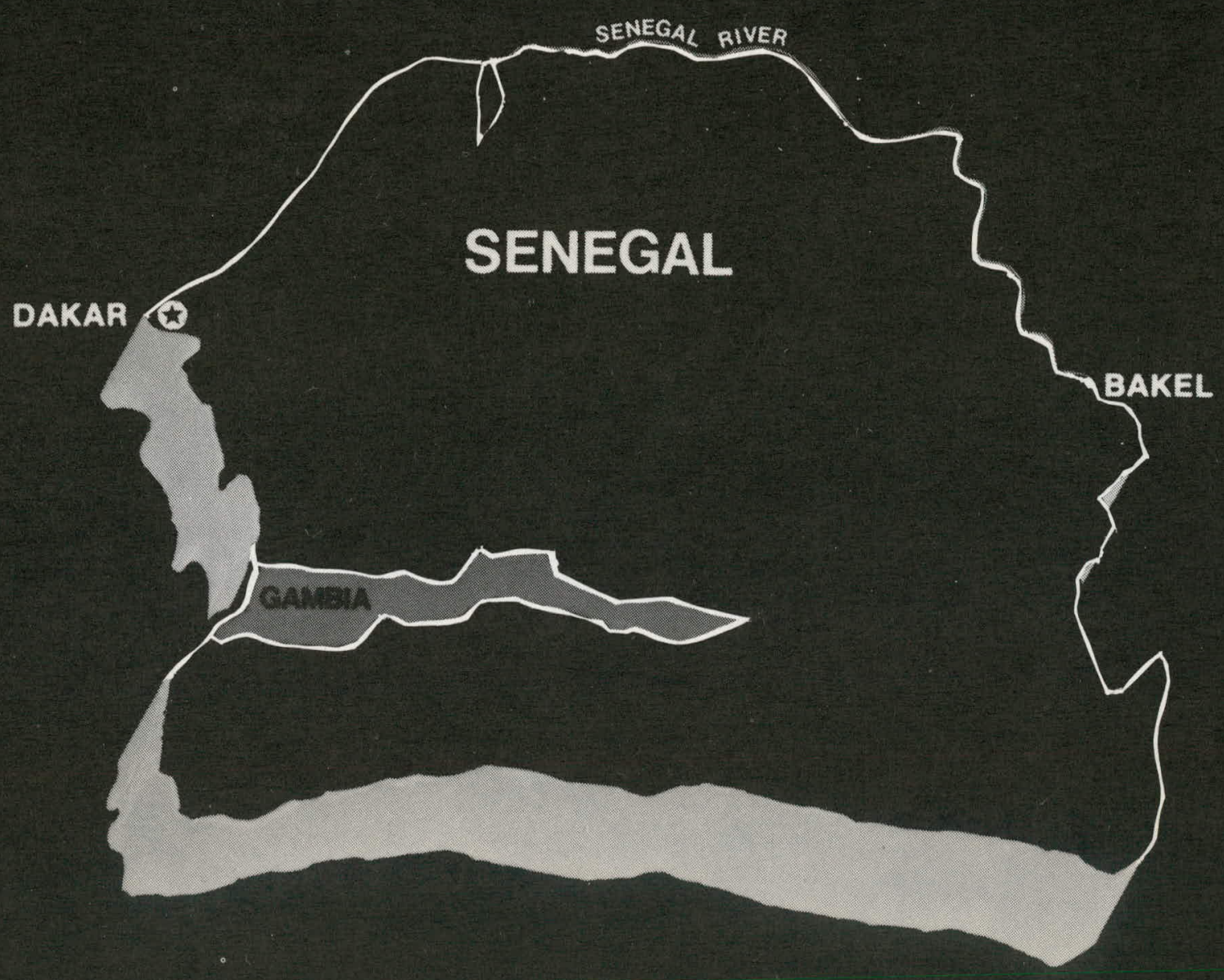

Figure 1. SENEGAL 


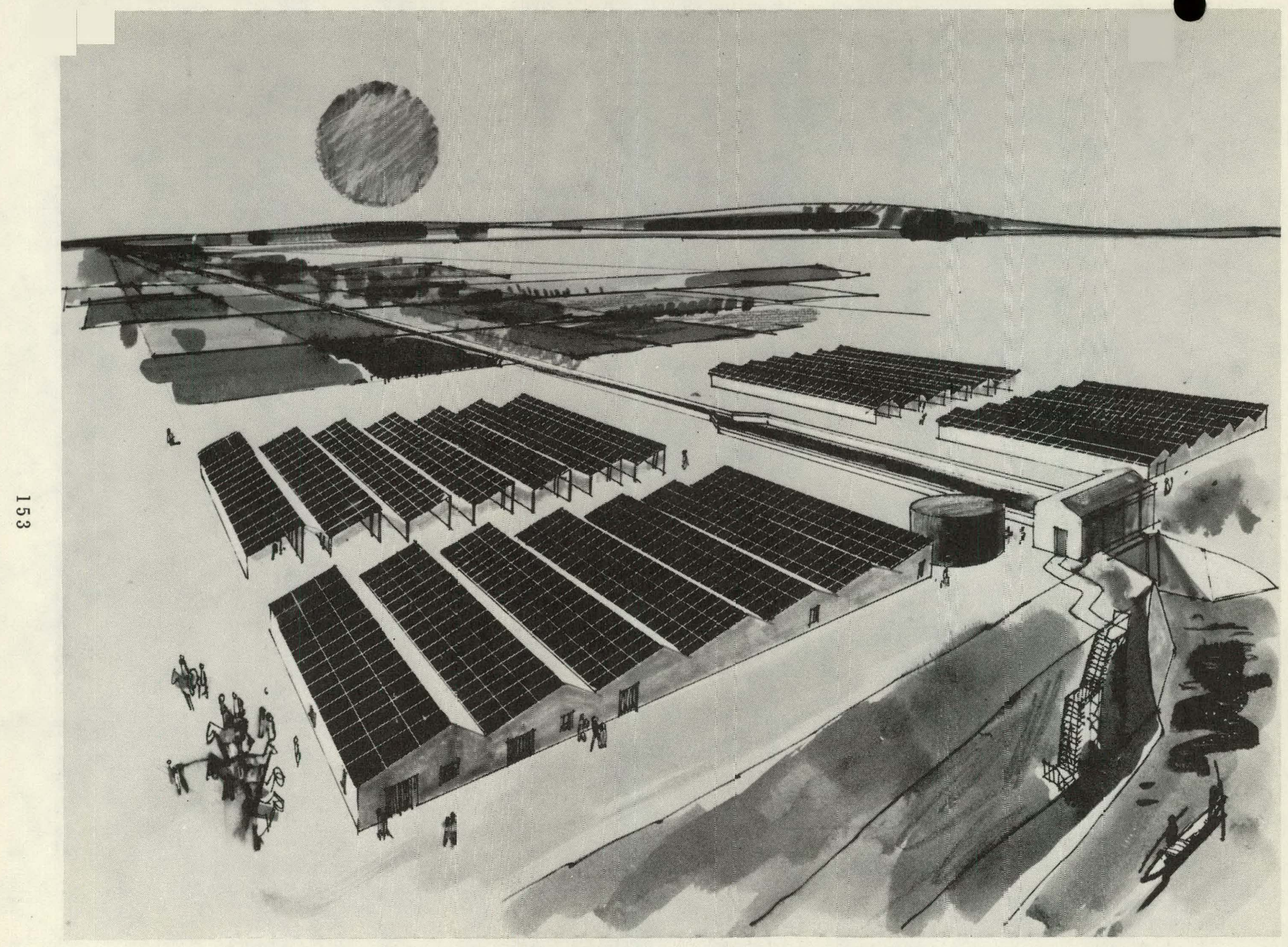

Figure 2. ARTISTS CONCEPTION OF THE BAKEL SOLAR IRRIGATIOI PLART 


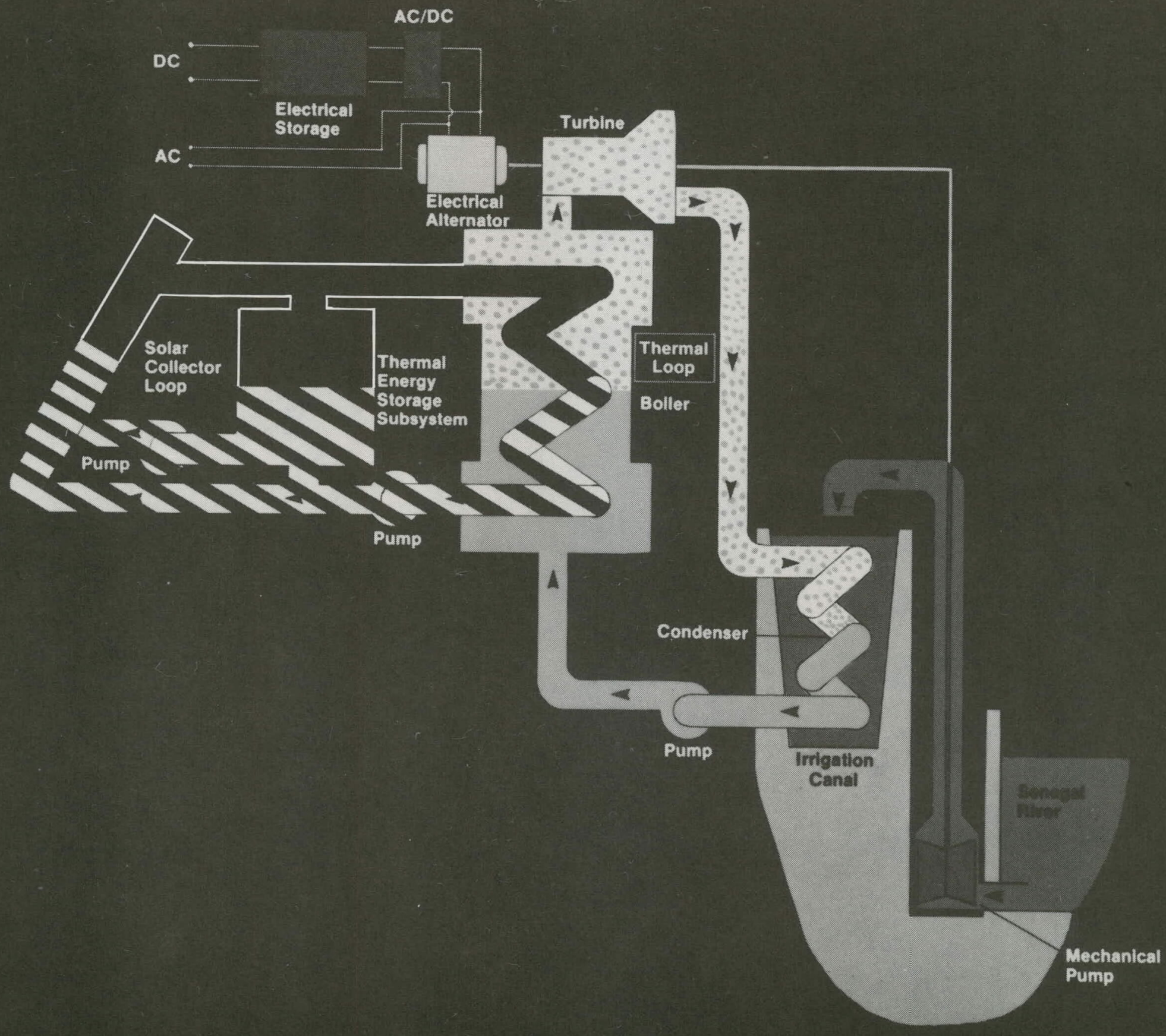

Figure 3. BAKEL SOLAR THERMAL. WATER PUMPING SYSTEM 


\title{
Advanced Energy Programs
}

\author{
Presented by \\ George P. Hellhake \\ General Electric Company
}

Philadelphia, PA 


\section{General Electric Advanced Energy \\ Programs}




\section{Company Components}

- R\&D Center

- Study Center

- Product Department

- Advanced Energy Department 


\section{Advanced Energy Programs}

- Solar

ज्ञ

- Wind

- Photovoltaic

- Nuclear 


\section{Advanced Energy Department}

- Profit and Loss Center

- 8 Years Domestic/3 Years International

- Hardware

- Projects

- Hardware

- Studies

- Development 


\section{Advanced Energy Department \\ International \\ Activities}




\section{International Activities}

- Spaiin

- Western Europe

- Mideast 


\section{Spain}

- IEA (Almeria)

Joint Proposal - No Bid

- Insufficient Funding

- Legal/Financial Considerations

- Transfer of Technology

- Grant-In-Aid

Joint Proposal (INI, Franklin Inst., GE)

- Proposal Cost Prohibitive

- Timing/Delays

- Administration

3 Companies

5 Government Agencies 


\section{Western Europe}

- Direct/Competitor

- High Technology Base

- Most Cost Competitive Government Support

- Tax Incentives

- Marketing Assistance

- Guarantees

- Margin Payments

- Export/Import Restrictions 


\section{Mideast}

- Hardware Sales but Problems

- After Sales Service

- Government Restrictions/Assistance

- Funding

- Project

- Stability of Government 


\section{Hardware}

- Cost

- Manufacturing/Marketing

- Transportation/Taxes/Duties

- Service/Training

- After Sales Service

- Competition

- Real

- Implied 
Projects

- Fragmentation of Responsibilities

- Government

- Co-Contractors

- Resources

- Limitations

- Technology Transfer

- Governmental Requirements

a.

- Contract

- Reporting

- Export/Import

- Legal

- Patents

- Liability Limits

- Warranties 


\section{Future}

- High Technology Products

- Established Company Channels for Distribution

- Joint Projects (W/Foreign Firms)

- Well Financed

- High Technology

- Stable Government

- Meaningful and Viable Work

Careful Selection of Opportunities 


\section{GROUP 1 REPORT}

Robert W. Willis, President

Solenergy Corporation

Wakefield, Massachusetts

The first item on our agenda involved something unclear concerning the Battelle study on photovoltaics which was to be presented to Congress in February. Perhaps someone from DOE can clarify this for us. The group's general comment on this issue was that the studies should be presented to the industry for its input prior to being submitted to Congress. We were not sure whether this would happen, but we wanted to indicate our feelings regardless. This suggestion also applies to market studies on heating and cooling. The group would also like to see a broader selection of witnesses go before the Congressional committees.

There was discussion about the cost of feasibility versus market studies, and the group thought that a lot of the studies being done were cost feasibility studies-particularly overseas-and that more general market studies should be accomplished. The main point the group wanted to make was that some of this information on the reports should go to SEIA for comments as well. We feel that the industry should participate with the government in the selection of countries because in some cases AID and some of the other government agencies have selected countries without determining which countries the industry is interested in.

One question came up: does AID specify "buy American"? The question was raised as to how American manufacturers know about jobs in foreign countries. There was some discussion about that in the Commerce Business Daily-not exactly entertaining reading. It was also brought up that there should be better dissemination of the GSA schedule. Personally, I thought that there was good dissemination, but the heating and cooling people would like more information on the GSA schedule. Some felt that DOE might update SEIA on a quarterly basis about foreign opportunities and SEIA could then distribute it to some of their members.

Concerning promotion, there was a question about selection of the countries in which the trade shows were held. It was mentioned that some country other than Australia could have been selected for the trade show for heating and cooling since there were perhaps 18 heating and cooling solar thermal manufacturers in Australia. Can DOC and DOE have the subsidies for foreign trade shows and foreign trade visits?

The group agreed that it would benefit everyone if some information package-perhaps prepared by SEIA or the government-were prepared and sent to all the embassies in the world to promote a clear understanding of photovoltaics and solar thermal energy, what the DOE program is, who the manufacturers are, and so forth. It was suggested that this information be put on microfiche because the embassies have microfiche capacities. This would be like the catalogue published by SEIA or DOE. The general feeling was that the government should be more prosolar.

It was also mentioned that the banking community evidently has been reluctant to back loans for customers with cost-effective applications. Although this happens to be in the United States, the group thought that it was worth bringing up because it could apply to 
overseas customers. The education of the banking community should be undertaken so they have at least basic knowledge about heating, cooling, photovoltaics, and other solar systems.

Banks should be informed of energy costs on domestic mortgages so they are aware of the rapid costs of oil versus solar energy. Can the government help some of the manufacturers in bid bonds that are required in a lot of overseas jobs and generally help create export incentives and provide stronger implementation of export/import programs?

There was a suggestion made that DOC or DOE develop solar trade centers in embassies of certain market areas where people could put their literature and perhaps even demonstrate small products. There was a lot of discussion about trade centers with foreign manufacturers, but general agreement was made that if the embassy is familiar with solar systems, perhaps the best thing to do is to have a verbal discussion with the embassy in the country in which a joint venture is proposed. The feeling was that a preproposal meeting should be scheduled to eliminate the surprise when some awards are made.

Installation of overseas jobs can be a problem for solar heating people. It is very difficult for someone in the United States to install something overseas, and they would like help from the embassy or DOE in selecting responsible local installers. Larger contracts in the photovoltaic area are desirable to reduce the number of productionrelated problems. Can there be any allowances made? It was acknowledged that some companies have distributors in countries DOE is putting demonstrations into. It was recommended that a first step in starting negotiating positions by the United States is to educate the negotiators. Another suggestion was to employ a release of funds so everybody can do all the planning. 


\section{GROUP 2 REPORT}

John Day

Strategies Unlimited

Los Altos, California

The following are highlights of the group's discussion on the five areas.

In the Assessments area, a need was expressed for more market information, particularly solar-related information. Most of the DOC information does not focus specifically on the solar issue. The group would like to see information on the structure of industry as it relates to solar application in, and solar-related problems of, individual countries.

The need for a central source of information was discussed at some length. Although a variety of information sources are available at present, accessing them is difficult because of a lack of a single coordination effort. The industry is faced with a growing number of new people entering the market who encounter problems trying to wade through the material. Such problems could be alleviated by the development of a central clearinghouse for information.

A need also was expressed for an ongoing bibliography of not only periodicals and books, but also conferences, workshops, meetings, and so forth. This would be most useful if it were well-publicized and people could get on the distribution list and receive regular copies.

The issue of workshops was discussed at great length. It was felt that workshops are needed which focus specifically on selected world geographic regions-such as Africa and the Mideast-to educate people from these areas and American industry about the problems of doing business in those regions. The underwriting of the cost of bringing representatives from those countries over to these workshops was suggested. There was discussion about who would be the appropriate person, but obviously that will need further research.

On the subject of promotion, the need for demonstration projects in a very diverse set of locations around the world was recognized. The point was made that these selections should be made according to business criteria rather than according to foreign policy criteria. The intent is to focus on the business opportunity regions rather than on what we would call foreign policy need areas.

Another issue concerned continued funding for maintenance and operational activities of installed sites and continued data collection. We do not simply want to do a demonstration and walk away from it. The issue of the costs of service around the world was mentioned. Experience through these demonstration projects would eliminate a lot of the uncertainty facing most of the American industry. The concensus of the group was that it would be appropriate for these projects to be funded by the U.S. government and the government of the country in which the project is installed. It was felt that if the foreign government made contribution to a demonstration project, they would be more likely to appreciate, understand, and use it. The industry does not want showcase demonstration projects, but projects that can be duplicated repeatedly and perhaps enable a market development activity for the U.S. industry. 
We had quite a discussion regarding Financial Aids. The issues of tax preferences for solar venture capital, the possibility of tax preferences for solar export promotional expenses, and interest-free loans for export were discussed at length. Pressure on foreign import duties for solar products was also mentioned. There seems to be difficulty in classifying solar products in some areas of the world. One photovoltaics supplier noted that he was being classified as a semiconductor and was looking for a lower duty. The solar bank was mentioned as a source of capital or debt loans for solar companies.

Another discussion on the financial area concerned the problem of money transfer, or getting the profit out of a foreign country after an installation has been made, and the role of the U.S. government in overriding product development costs for products associated with the export market. It was felt that many of the development funds that are presently divided through DOE may be more geared to domestic rather than foreign applications. Some thought should be given to specifically identifying the export products and letting some of these export funds be directed into products geared to the foreign market.

The usual comments were made on trade barriers and tariffs. We had quite a discussion on the proper role of DOE/SERI versus DOC in promoting the export of solar products. There was general consensus on a need for an integrated program of ISCWG which would bring together the different parts of the government and industry. This should be a coordinated effort, initiated, some felt, by DOC. The reason DOE entered this was because there was not enough moving in DOC, but it was throught that ultimately this role of export should be coordinated through DOC.

The group agreed that the meeting was very useful. The hope was expressed that the momentum of industry-government dialogue would be continued. One point in particular was emphasized at the conclusion: we do not want to leave the impression on our government representatives that industry perceives of the government as the panacea for everyone's problems. This is not the case: obviously industry is responsible for carrying its share of the burden. We want to emphasize our desire to work on a cooperative basis with the government.

Concerning the issue of large business versus small business: if, as stated this morning, there are reasons why large business does not want to undertake a high-risk solar business because it may jeopardize larger industrial sales of other products, and small business cannot undertake this kind of high risk for lack of resources, the question is, who is going to do it? Maybe Acurex is the right size after all.

The question of business size also ties in directly with the issue of financing this foreign development activity. There was quite a discussion on technology transfer. Although nothing was resolved, there was general worry and concern on the part of industry regarding government-owned patents for licensing to foreign markets. No one is sure what is going to happen legally with respect to technology developed under the Jet Propulsion Laboratory (JPL) or DOE programs. What about all of this transfer overseas to foreign competitors? The question is: is solar a strategic technology? It was generally concluded that there are no real answers at present and the whole issue needs much more examination. 


\section{GROUP 3 REPORT}

Mike Curcurullo, Energy Programs

Grumman International Company

Bethpage, NY

We had considerable discussion of government reports in the Assessment category. The general concensus of the group was that such reports are beneficial as far as they go. It was suggested that SEIA be requested to develop specific recommendations as to the contents of these reports, as well as to recommend the order of priorities of what countries should be reflected in the information. Questions were raised on the in-country utility plans, the overall general government plans, the marketing techniques, and the utility costs. The other comment on reports concerned problems related to the long turnaround time of government reports.

In the area of Promotion, we briefly discussed an international guidebook which would present an overview. of the technology of the United States and some of the economies of the energy systems. This idea was generally well-received. These publications would be distributed to industries for dissemination to interested parties who request them. Demonstration sites in particular countries were also discussed. Participation could be shared between industry and government, or perhaps with the demonstrating countries and the U.S. government without industry involvement. No resolution was reached on that issue. The important point was that the equipment must work in the particular environment for which it was designed and must be maintained. Also under Promotion, there was a brief discussion about the idea of a traveling scientist who could sell American technology with contacts at the very highest levels of foreign governments.

Under the topic of Communications, our group had mixed emotions regarding the proposed newsletter. Most of the people who have been in the industry for awhile prefer the personal contacts and the existing lines of communication. They do not feel such a newsletter would be useful. The important point under Communications was that we want to make sure that SEIA knows of all the government services available to the industry. A couple of comments were made about the amount of information which really exists, and we felt that SEIA was a good avenue to disseminate this information. Perhaps in the future they should have more specific objectives and individuals with expertise in certain areas.

In the Financial Aid category, there was brief discussion on the need to fund and develop or modify existing systems in particular areas of the world. We discussed available funding for this, and it was felt that funding would have to be an additional line item to fit into the budget. Existing funds were probably not available for this but the concept was well-received. 
THIS PAGE INTENTIONALLY LEFT BLANK 


\section{GROUP 4 REPORT}

Michael Belanger, Marketing Manager

Daystar Solar Energy Group

Exxon Enterprises, Inc.

Burlington, Massachusetts

Under the subject of Assessment, we are basically looking for someone to provide us with a profile of very specific information through existing sources which must be capable of rapid update and accountable to the quality of the data produced. Someone speculated that we could use the career counsulates, the native employees who have been thoroughly briefed on the solar industry's input and who can be rewarded through their employment efficiency reports. Examples of data we want included: competitive product and pricing data; competitive out-of-pocket costs of existing energy sources for specific countries of interest; projection of energy planning by each government; and translation of data on foreign markets available in the countries of our own competitors, for instance, from Japanese, German, and French sources.

The Communications discussion revolved around industry participation and all project screening with other countries, especially negotiations for treaties and other agreements, the compilation of a bibliography of data, and a library to access this data. We also expect the industry to define microdata useful for analysis. It was felt that the SEIA would be the main clearinghouse and that with enough cooperation from all sides, the SEIA would be a stronger group and would have a much more powerful role in assisting our focus. In addition, we would expect the SEIA to have industry participants whose costs would be funded, hopefully by DOE (i.e., air fare, meals, etc.). We would expect the industry people to continually evaluate the data and redefine the data needs. We would do this by market segment; i.e., subgroups in photovoltaics, solar thermal, bio, wind, and central power stations. The last item discussed under Communications was access to current intelligence on local political and economic conditions on a country-bycountry basis.

Under Promotion, we urged lower cost trade shows. We would like to see an extensive intelligence briefing of our foreign service staff to enable them to provide us with timely feedback on the critical data we identify.

We intend to use the solar lobby in Congress-which is very strong-in our behalf to establish this foreign service program. We also discussed the DOE demonstrations abroad: in order for these to operate effectively, we have to find a mechanism to make them representative of the solar industry as a whole, not dominated by the larger firms. We also had some comments about the need for specific R\&D funding from DOE for the development of equipment and systems not for use in the United States but strictly for the export market. I tried to promote getting an old aircraft carrier out of moth balls and filling the deck with solar collectors to run the engines and fill it up with a permanent trade fair and send it around the world, but nobody bought that.

During the Financial Aid discussions, we examined mechanisms for possibly removing the impact of foreign taxes. Another suggestion was to develop incentives to stimulate the growth of successful exporting firms, and some reward mechanism for those who did their homework and were successful at it. 
THIS PAGE INTENTIONALLY LEFT BLANK 


\section{GROUP 5 REPORT}

Jonathan P. Schlesinger, Director

International Division

Northrup Incorporated

Hutchins, Texas

Under the heading of Assessment,the literature by DOC and especially the new material from DOE are what we are looking for. We would like to see much more solar information as well as a lot more information regarding energy costs in various potential markets around the world. We had a man from DOC in our group, who assured us that programs for this additional information were in the pipeline.

It was also felt that many of the commercial reports that were sent out were somewhat outdated by the time they were received. Although it is probably difficult to improve this situation, nevertheless it is a problem. It was suggested that a newsletter could be published either as part of the Commerce Business Daily, or that SERI could under take a completely new venture. The purpose would be to keep American solar industry posted on the status of the industry worldwide and to print what could be bid for in various countries including the United States. We were told that in studies done recently for DOE that someone was sent by DOE to participate with the contractor in gathering information throughout various countries. The various trade attaches in those countries who previously had not really been exposed to the solar industry became rather excited. Thus, education of DOS and DOC personnel in the field as mentioned earlier could be very important in assisting the industry.

It was also mentioned that there are certain five-year plans for various countries that are obtainable through DOC. Not many people seem to know about these, but it was suggested that more information should be disseminated which is presently available but not initially distributed to companies. Another suggestion was to publish lists of U.S. solar industries that could be distributed to perspective foreign purchasers or licensees, as well as lists of foreign solar companies that U.S. companies could approach. It will be important to keep these lists up-to-date once they are established.

One of the problem areas we identified was the lack of any effective SIC coding for solar equipment. At present, solar products fall into various general categories, such as photovoltaics being included under the semiconductor code as mentioned earlier. A clearer definition would facilitate easier access (through a computer list) of the type of company a U.S. firm would either want to sell to or deal with in various countries. The need was also expressed for some means of identifying the type of contractors available to local companies for installing their equipment within foreign countries. Nothing is presently being done about this, but it was suggested that someone could approach the various professional associations in this country as a means of contacting professional associations in other countries. Possibly DOE or DOC could compile or assist in the compilation of such a list.

Under the heading of Communication, the problem of the six-month minimum time lag was raised, and the subject of the SERI newsletter was discussed. It was felt that although most companies who wanted the available information could obtain it without difficulty, the smaller companies who did not feel they were ready for exporting did not request it, thus making it hard to reach such companies. With regard to this, the point was raised that three or four seminars related to solar exports will be organized by SERI 
and DOE across the United States, and that it would be advantageous to determine whether a market for these small companies exists in the international forum before seminars encouraging them to enter the market are conducted.

Regarding Promotion, there was general favorable reaction to promotions such as trade missions, and the trade fairs sponsored by the U.S. trade centers in various parts of the world-both the market research done before a show and the organization during it.

The discussion on Promotion led quickly into the subject of Financial Aid because the concensus was that although good market research and promotion are essential, the key is to have a competitive advantage in the marketplace. In this case, a product must be able to compete with exports from France, Germany, and many other countries that have received much more assistance than U.S. industry has from this government. This problem is not restricted to marketing of solar energy products: it is a basic issue of the difference between American exporters and exporters in other parts of the world. We feel that our major problem is that the export subsidies or incentives the U.S. exporters get are insufficient. Apparently a committee called the Barusch Committee is meeting at the moment which is scheduled to report in February to the President on various tax considerations as linked to exports. It was felt that they should be contacted as soon as possible. The suggestion was also made that the solar industry could use export subsidy to assist this country's competitive advantage in the foreign marketplace.

Under the General heading, we put the basic heading of political aspects of foreign cooperative programs related to and versus the private and commercialization aspects. We felt that there was conflict in certain areas. It was agreed that anyone can buy a piece of hardware, and try to assemble it, so the cooperative effort that DOS and DOE are spearheading would not really affect the equipment itself. In terms of technology and know-how, however, it was felt that the equipment may be exposed in such a way that could be detrimental to the private industry interests. We felt that there was a certain naivete in the interactions with foreign countries-not exactly a lack of understanding, but rather a lack of recognition concerning the relationship that some U.S. companies have with certain foreign companies, part-ownership or otherwise.

We would like to see government look very closely at the possible profitability of any cooperative program to the solar industry before such a program is implemented. Much more interaction between government and industry is recommended before any cooperative effort is actually made, including the consultation of certain industry members in the negotiating process. Generally, we felt that the government sector is not giving enough importance to the possible median and long-term effects of cooperative agreements. The hope was also expressed that government will view export technology and the possibility of exports in a much more serious way. There was endorsement that the demonstration program utilizing U.S. buildings in foreign countries would be very important for our industry and that this will hopefully happen soon. 


\section{Issues}

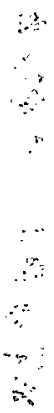




\section{ISSUES \\ IDENTIFIED BY THE SOLAR INDUSTRY \\ AT THE "DOE/SOLAR EXPORT WORKSHOP" \\ A tlanta,-G.A-e
-Januar-y-8-1-0,-1-979}

\section{GENERAL}

The Workshop achieved the goals of the International Solar Commercialization Working Group (ISCWG) to initiate a meaningful dialogue between the U.S. solar industry and U.S. Government Agencies to stimulate and encourage exports. Industry representatives clearly indicated a requirement for selective assistance from government and the opportunity to influence DOE and other agencies in the formulation of policies related to international solar energy commercialization.

\section{Problems}

Session V discussions covered government and industry roles and responsibilities with regard to export-related activities, issues, and problems. During these discussions several important problems were identified as follows:

\section{A. Assessment}

1. Need more up-to-date information on

- foreign government plans on energy

- foreign competitors

- foreign market opportunities

- transportation facilities and cost

- costs of existing energy sources

- suitable associates for solar ventures

2. Most studies are cost feasibility studies rather. than market studies.

3. Most of DOE infor mation does not focus specifically on the solar problem.

4. Necd market information for solar energy products rather than other commercial products.

5. Solar energy-related infor mation should be centralized.

6. Reports are outdated by the time received. Suggest an export newsletter in CRn or other suitable for $m$. 
7. Industry would like to comment on studies before recommendations are made to Congress.

8. The effects of technology transfer on U.S. export potential should be studied.

B. Communications

1. Need for ongoing bibliography of not only periodicals and books, but also conferences, workshops, meetings, etc.

2. Workshops should focus on selected world geographic regions specifically.

3. Education of State and Commerce Department personnel in the field on solar is important.

4. Workshops should have a specific objective. Individuals in attendance should have specific contributions to make.

5. Business prefers personal contacts and existing lines of communications.

6. Industry and its associations should be cognizant of all government services available to industry.

7. Better communication between U.S. Government and industry including industry advice and participation, through representative organizations, in planning and bilateral agreements.

C. Promotion

1. Provide International Guide Book, including marketing techniques with overview of technology, products and services in the United States, manufacturers, and economics of energy systems. Make guide book available to embassies, etc.

2. Companies to participate in demonstration projects sites in particular countries. Projects would demonstrate actual in-country use and emphasize local environment and maintenance. Projects should include operations and Inaintenance efforts with consideration of joint funding between the United States and host country governments.

3. Consider traveling scientists who can discuss American technology at the highest level in foreign countries, to sell American technology.

4. More and lower cost trade shows. Extensive solar intelligence briefings of Foreign Service staffs for quality and timely feedback of critical data.

5. Government sponsored R\&D specifically for the export market.

D. Financial Aid

1. DOC incentives for rebating the impact of foreign value added taxes. 
2. Favorable incentives to stimulate growth of successful exporting firms: i.e., tax preference for solar venture capital, export promotion expenses, and low cost loans and guarantees.

3. Government provide bid bond.

4. Government fund development of systems/products unique to areas of the world.

5. Solar development bank to make capital loans to solar companies.

E. Other

1. What is role of DOE/SERI and DOC to promote export of solar?

2. Industry is concerned regarding government-owned patents for licensing to foreign markets.

3. Industry should participate with government to select target countries for export emphasis.

4. AID and other agencies may have selected countries without determining industry's interest. Concern expressed about AID "buy American" policy.

5. Government should be more pro-solar.

6. Provide specific aids for small businesses.

7. Separate international classification of solar products and favorable tariffs.

\section{PRELIMINARY ISSUES}

The principal issues arising from the Workshop have been re-cast for convenience into the major categories summarized below. These issues could form the basis for a series of more specific Export Workshops that will culminate rapidly in specific action recommendations. These recommendations will be those upon which industry and government agree as to:

a. Beneficial impact on the U.S. solar industry at home and abroad.

b. Equitable nature in terms of the various interests of industry and its segments on the one hand, and government responsibilities on the other.

The major issues are outlined below (subject to modification as the dialogue continues):

1. Information

The primary ISSUE is the extent to which the U.S. Government should make a special effort to acquire and disseminate data to U.S. industry, including training programs and data packages pertaining to solar export and international commercialization. 
A parallel ISSUE is whether or not such data-and other related information obtained by the U.S. Government or under Government auspices for U.S. industry-could be protected from foreign competitors and governments.

2. Financial and Promotional Assistance

In addition to information, the U.S. solar industry needs outside help in order to be competitive overseas. Such help could be in the form of financial incentives including tax relief, low interest loans, $R \& D$ and other contracts, rewards and other aid to exporters, and so on. Also, stronger support could be provided in the form of trade fairs and missions, export subsidies, and promotion by U.S. officials abroad. In addition, more attention should be focused on U.S. regulatory practices on solar exports to increase incentives arid decredse burrier's fur U.S. compunies interested in solar export markets.

The ISSUE is whether or not the U.S. Government should provide special effort to the U.S. solar industry through financial and promotional assistance, and if so, to what extent?

3. Industry Input

It is widely believed in the U.S. solar industry, that the U.S. Government is paying too little attention to the views and needs of industry during the process of planning and conducting U.S. foreign energy activities, particularly AID and DOE bilateral and multilateral ngrcements. A meaningful role could be defined for various associations representing solar industry as to their specific involvement in these agreements as well as participation in ISCWG activities.

The ISSUE is the manner and degree of U.S. solar industry involvement in providing a viewpoint and requirements to the U.S. Government to ensure consideration in the formulation and conduct of such agreements and activities.

4. Technology Transfer, Patents and Licensing Issues

The U.S. solar industry has an advantage in international commerce over many countries in certain fields of higher technology. If transfer of technology abroad by the U.S. Government occurred without regard for the interest of U.S. industry it could easily and rapidly erode any advantages. In time, potential customers may become successful sompetitors.

The ISSUE is whether or not the U.S. industry should participate in the planning and decisionmaking processes that could lead to such Government transfers of technology, and if so, in what manner and in regard to what types of technologies? 


\section{An Extraordinary Eff ort}

At present, the U.S. solar industry receives a minimum of special attention from the Federal Government on export market development. Other segments of the energy sector (such as the nuclear industry) enjoy special advantages and strong financial support.

The ISSUE is whether or not the U.S. Government should make an extraordinary effort to provide the U.S. solar industry with the export assistance necessary for a strong and rapid market development. This would encourage a near term export industry based on, and stimulating, a strong domestic market and industry. 
THIS PAGE INTENTIONALLY LEFT BLANK 
Attendees 
January 9-10, 1979

Sheraton/Eiltmore Hotel Atlanta, Georgia

Julia C. Allen

PRC/Energy Analys is Company

7600 01d Springhouse Road

McLean, VA 22104

703/893-1800 ×2856

Jorge R. As in

IBS Inc.

1010 Vermont Avenue, NW

Washington, DC 20005

202/789-5200

Bill Babcock

Booz, Allen \& Hamilton

43.30 East West Highway

Bethesda, MD 20014

301/951-2557

Michael Belanger

Exxon Enterprises Inc.

Daystar Solar Energy Group

90 Cambridge

Burlington, MA 01803

$617 / 272-8460$

Justin A. Bereny

Solar Energy Information Services

18 2nd Avenue

P.0. Box 204

San Mateo, CA 94401

$415 / 347-2640$

John Bierman

Export/Imort Bank

811 Vermont Avenue

Washington, DC 20571

202/566-8806; FTS 566-8806

R. V. Ronterou

Bontecou Associates

Pilot Knob, NY 12844

518/656-9465

J. Jeff Boshar

Novan Energy Inc.

334317 th Street, NW

Washington, DC 20010

202/483-8051
Jerome J. Bosken

Agency for International Development Washington, DC 20523

703/235-1720

John C. Bowen

Ametek, Inc./Power Systems Group

One Spring Avenue

Hatfield, PA 19440

215/822-2971

Ronald S. Burke

One Design, Inc.

Route 2, Box 792-C

Front Royal, VA 22630

703/635-7489

S. H. Butt

01 in Brass

E. N1ton, IL 62024

$618 / 258-2770$

Richard S. Campbell

Pattelle Pacific Northwest Lab

P.O. Box 999

Richland, WA 99352

509/942-4249

Paul R. Carpenter

Jet Propulsion Laboratory

4800 Oak Grove Drive

Pasadena, CA 91103

213/577-9217

John F. Connelly

Energy Converters, Inc.

2501 N. Orchard Knob Avenue

Chattanooga, TN 37406

615/624-1594

William L. Corcoran

DOE

20. Massachusetts Avenue, NW

Washington, DC 20545

202/376-9605; FTS 376-9605 
Mike Cucurullo

Grumman International Co.

1111 Stewart Avenue

Bethpage, NY 11714

516/575-6801

John Day

Strategies Unlimited

500 University Avenue

Los Altos, CA 94022

415/854-4672

Joseph Deahl

Solar Usage Now, Inc.

Box 306

Bascom, $\mathrm{OH} \quad 44809$

419/937-2??6

James H. Dood

Wyle Laboratories

2361 Jefferson Davis Hwy. \#404

Arlington, VA 22202

703/892-6700

David W. Doyle

University of Alabama/Huntsville

Johnson Environmental \& Energy Ctr.

10705 Stanmore Drive

Potomac, MD 20854

$301 / 299-6676$

Dr. John E. Dwan, I I

McDonnell Douglas

5301 Bolsa Avenue

Huntington Beach, CA 92647

$714 / 896-4822$

John C. Engle

International Business Services

1010 Vermont Avenue, NW

Washington, DC 20005

202/789-5265

Roger R. Ethier

Planning Research Corp.

old Courthouse Road

McLean, VA 20134

703/893-1800

Andrew D. Farrel1

IIT Research Institute

$1825 \mathrm{~K}$ Street, NW, Suite 610

Washington, DC 20006

202/296-1610
Richard L. Foley

Arco Solar, Inc.

2021 Wallace Street

Philadelphia, PA 19136

215/557-3004

M. W. Frank

Entropy Limited

5735 Arapahoe

Boulder, CO 80303

303/443-5103

Pichard Garnitz

Department of Commerce

Washington, DC 20230

202/377-4231; FTS 377-1231

Conrad Gohlinghorst

Copper Development Corporation

1011 High Ridge Road

Stamford, CT 06905

203/322-7639

Murrey D. Goldberg

SER I

1536 cole Blvd.

Golden, CO 80401

$30.3 / 2.31-1218$

Hamilton E. Guice

Solar Technic International, Inc.

9459 Timberleaf Dr.

Dallas, TX 75243

214/243-1033

Yousuf H. Habib

Exxon Enterprises, Inc.

1251 Avenue of the Americas

New York, NY 10020

212/398-3756

Robert E. Hedden

Mueller Associates, Inc.

1900 Sulphur Springs Road

Baltimore, MD 21227

$301 / 247-5666$

William J. Heidrich

Revere Solar \& Architectural Products P.0. Box 151

Rome, NY 13440

$315 / 338-2401$ 
Gerald Hein

NASA/Lewis Research Center

21000 Brookpark

"eveland, $\mathrm{OH} \quad 44017$

6/433-4000

George Hellhake

General Electric Company

P.0. Box 8555

Philadelphia, PA 19101

215/962-1082

Lloyd 0 . Herwig

Department of Energy

600 E Street, NW, Rm. 418

Washington, DC 20545

202/376-4745; FTS 376-4745

William T. Hudson

Independent Living Inc.

5965 Peachtree Corners East

Atlanta, GA 30071

404/449-5900

Bob Jackson

SERI

1536 Cole Bivd.

Golden, CO 80401

303/231-1235; FTS 327-1235

Sarah Jackson

DOE/IA

Mail Stop 2104

Washington, DC 20585

202/254-6840; FTS 254-6840

Robert 0 . Johnson

SES, Inc.

Tralee Industrial Park

Newark, DE 19711

703/892-2500

Raymond Kendall

Motorola - GED

1745 Jefferson Davis Hwy.

Suite 301

Arlington, VA 22202

703/892-2500

Stephen Klein

Agency for International Development

Department of State

Washington, DC

?02/632-9113; FTS $632-9113$
George M. Kohler

Foster Wheeler Solar Development Corp.

12 Peachtree Hill Road

Livingston, NJ 07039

201/533-3605

Thomas M. Lange

Helios International Corp.

2120 Angus Road

Charlottesville, VA 22901

804/977-3719

Irwin Lesser

RCA

30 Rockefeller Plaza

New York, NY 10020

Robert S. Levi

IIT Research Institute

10 West 35th Street

Chicago, IL 60616

312/567-4609

Greg T. Love

SES, Inc.

Tralee Industrial Park

Newark, DE 19711

302/731-0990

Norman W. Lutkefedder

DOE

20 Massachusetts Avenue, NW

Washington, DC 20545

202/376-9633; FTS 376-9633

Ronald W. Matlin

MIT/Lincoln Laboratory

144 Wood Street

Lexington, MA 02173

$617 / 862-5500 \times 213$

Brad M. Mead

Grumman International Company

1111 Stewart Avenue

Bethpage, NY 11714

516/575-6801

James D. Mendenhall

Solar Assist. Corp./Kansas Sun-Day

P.0. Box 979

Lawrence, KS

66044

913/843-9808

Daniel A. Mazzeo

Georgià Tech/Eng'g. Exp. Station

225 North Avenue

Atlanta, GA 30332

404/894-3623 
William R. Mengel

The BDM Corporation

7915 Jones Branch Dr.

McLean, VA 22180

703/821-5078

William Micchelli

Science Applications, Inc.

8400 Westpark Dr.

McLean, VA 22102

703/821-4300

James C. Muller

Georgia Tech/Eng'g. Exp. Station

225 North Avenue

Atlanta, GA 30332

404/384-3816

James R. Nash

Sunbelt Solar International

2418 Tangley

Houston, TX 77005

713/524-2995

Gary J. Neuner

Acurex Corp./Aerotherm Group

485 Clyde Avenue

Mt. view, CA 94042

415/964-3200 ×3343

James W. O'Brien

Thermo Electron Corp.

85 First Avenue

Waltham, MA 02154

$617 / 890-8700$

Michael T. Panich

PRC Energy Analysis Co.

$760001 d$ Springhouse Rd.

McLean, VA 22102

703/893-1820

Pandit Patil

Systems Consultants, Inc.

105431 st street. NW

Washington, DC 20007

202/342-4630

Floyd C. Perry

Sunworks, Division of Enthone, Inc.

P.0. Box 1004

New Haven, CT 06508

?03/934-6301
Martin Prochnik

Department of State/OES

Washington, DC 20520

202/632-4413; FTS 632-4413

Garry L. Quinn

Boeing Engineering \& Constr. Co.

955 L'Enfant Plaza, SW

Washington, DC 20024

202/488-4090

Clyde Ragsdale

Motorola Inc.

5005 E. McDowe11 Rd.

Phoenix, AZ 85008

602/244-3796

Leonard J. Ratl iff

Sunbelt Solar International

2418 Tangley

Houston, TX 77005

713/524-2995

David R. Reese

Wyle Laboratories

7800 Governors Dr.

Huntsville, AL 35807

205/837-4411

Vincent Riley

World Bank

1818 H Street, NW

Washington, DC 20433

202/676-1174

Guy A. Roderick

Photon Power, Inc.

10767 Gateway West

El Paso, TX 79935

915/593-2861

Jerome $D$. Rosenberg

DOE (NASA)

20 Massachusetts, NW

Washington, DC 20515

202/376-9642; FTS 376-9642

Jerry A. Rosenberg

Aquarian Research

2623 NW 74th Place

Gainesville, FL 32601

904/375-0406 
Eli B. Roth

Consulting Engineer

4204 Glenridge Street

Kensington, MD 20795

$11 / 933-7810$

Arthur I. Rudin

Arco Solar, Inc.

20554 Plummer St.

Chatsworth, CA 91311

213/998-0667

Neil B. Saunders

Container Graphics Corp.

P.0. Box 3403 Station C

Toledo, $\mathrm{OH} 43614$

419/537-8600

Larry Scudder

NASA/Lewis Research Center

21000 Brookpark Rd.

Cleveland, $\mathrm{OH} \quad 44017$

$216 / 433-4000 \times 305$

Jonathan $P$. Schlesinger

Northrup, Inc.

1150 First National Bank Bldg.

Dallas, TX 75202

$214 / 741-7546$

Ishaq Shahryar

Solec International

12533 Chadron Avenue

Hawthorne, CA 90250

213/970-0065 or 213/553-1845

Eve A. Shelton

Energy Systems International

8301 Greensboro Drive

McLean, VA 22102

703/827-0303

Art Sherman

RCA Solar

Princeton, NJ 08541

609/452-2700

James F. Skane

Solar Power Corporation

20 Cabot Road

Woburn, MA 01801

617/935-4600
John L. Sloop

PRC Energy Analys is Company

7600 01d Springhouse Road

McLean, VA 22101

703/893-1800 ×2631

Elaine Smith

DOE

20 Massachusetts Avenue, NW

Washington, DC 20545

202/376-5933; FTS 376-5933

Robert C. Spongberg

SERI.

1536 Cole Blvd.

Golden, C0 80401

303/231-1837; FTS 327-1837

Wayne $C$. Stevenson

Optical Coating Laboratories, Inc.

15251 E. Don Julian

City of Industry, CA 91746

213/968-6581

George C. Szego

ITC/Solar Corporation

100 Main Street

Warrenton, VA 22186

703/347-7900

A. Nelson Tardiff

DOE/International Affairs

Forrestal Building

Washington, DC 20245

202/252-6383; FTS 252-6383

Janet G. Thomas

U.S. Department of Commerce

Washington, DC 20230

202/377-4462; FTS 377-4462

Peter Thompson

American Solar King Corp.

6801 New McGregor

Waco, TX 76710

$817 / 776-3860$

Albert Thumann

Association of Engineers

464 Armour Circle, NE

Atlanta, GA 30345

404/874-8188 
Thomas V. Vakerics

0'Connor \& Hannan

1747 Pennsylvania Ave., NW

Suite 600

Washington, DC 20006

202/785-8700

Milton A. Van Horn

General Electric Company

Space Division

P.0. Box 8661

Philadelphia, PA 19101

215/962-1035

Raymond D. Watts

Blum, Parker, \& Nash

1015 18th Street, NW

Suite 408

Washington, DC 20036

202/857-0220; 'FTS 857-0220

Hoyt M. Weathers

NASA

Marshall Space Flight Center

Huntsville, AL 35673

205/453-2054

Robert $L$. Weinberg

RCA

David Sarnoff Research Center

Princeton, NJ 08540

609.1452-2700

Thomas G. West

PRC Energy Analysis Company

7600 01d Springhouse Rd.

McLean, VA 22101

703/893-1820

Robert W. Will is

Solenergy Corporation

23 North Avenue

Wakefield, MA 01880

617/246-1855

Francis E. Wilson, Jr.

Export/Import Bank

811 Vermont Avenue, NW

Washington, DC 20005

202/383-8400; FTS 383-8400
Jack Vanderryn

DOE/International Affairs

Mail Stop 7F-031

Washington, DC 20585

202/252-6140; FTS 252-6140

Herbert C. Yim

Energy Systems International

8301 Greensboro Drive

McLean, VA 22102

703/827-0303

SUPPLEMENT Judy M. Lea

Energy Systems International 8301 Greensboro Drive

McLean, VA 22102

703/827-0303

Fred S. Fleischman

SBA

1375 Peachtree Street, NE

Atlanta, GA 30309

404/881-4948

John T. Keiser

Thermo Electron Corporation

101 First Avenue

Waltham, MA 02154

$618 / 890-8700$ 